UNIVERSIDADE DE SÃO PAULO

ESCOLA DE ARTES, CIÊNCIAS E HUMANIDADES

PROGRAMA DE PÓS-GRADUAÇÃO EM MODELAGEM DE SISTEMAS COMPLEXOS

WILLIAN WAGNER LAUTENSCHLAGER

Um modelo estocástico de simulação da dinâmica dos queratinócitos, melanócitos e melanomas no desenvolvimento dos tumores 


\section{Um modelo estocástico de simulação da dinâmica dos queratinócitos, melanócitos e melanomas no desenvolvimento dos tumores}

Dissertação apresentada à Escola de Artes, Ciências e Humanidades da Universidade de São Paulo para obtenção do título de Mestre em Ciências pelo Programa de Pós-graduação em Modelagem de Sistemas Complexos.

Versão corrigida contendo as alterações solicitadas pela comissão julgadora em 17 de março de 2017. A versão original encontra-se em acervo reservado na Biblioteca da EACH/USP e na Biblioteca Digital de Teses e Dissertações da USP (BDTD), de acordo com a Resolução CoPGr 6018, de 13 de outubro de 2011.

Área de Concentração: Sistemas Complexos

Orientador: Prof. Dr. Alexandre Ferreira Ramos

\section{SÃO PAULO}


Autorizo a reprodução e divulgação total ou parcial deste trabalho, por qualquer meio convencional ou eletrônico, para fins de estudo e pesquisa, desde que citada a fonte.

CATALOGAÇÃO-NA-PUBLICAÇÃO

(Universidade de São Paulo. Escola de Artes, Ciências e Humanidades. Biblioteca)

Lautenschlager, Willian Wagner

Um modelo estocástico de simulação da dinâmica dos queratinócitos, melanócitos e melanomas no desenvolvimento dos tumores / Willian Wagner Lautenschlager; orientador, Alexandre Ferreira Ramos - São Paulo, 2017.

76f.: il.

Dissertação (Mestrado em Ciências) - Programa de Pós-graduação em Modelagem de Sistemas Complexos, Escola de Artes, Ciências e Humanidades, Universidade de São Paulo.

Versão corrigida.

1. Biologia molecular - Simulação computacional. 2. Biologia molecular - Modelos matemáticos. 3. Melanoma. 4. Dinâmica estocástica. I. Ramos, Alexandre Ferreira, orient. II. Título

CDD 22 ed.- -572.80285 
Nome: LAUTENSCHLAGER, Willian Wagner

Título: Um modelo estocástico de simulação da dinâmica dos queratinócitos, melanócitos e melanomas no desenvolvimento dos tumores

Dissertação apresentada à Escola de Artes, Ciências e Humanidades da Universidade de São Paulo para obtenção do título de Mestre em Ciências pelo Programa de Pós-graduação em Modelagem de Sistemas Complexos.

Área de Concentração: Sistemas Complexos

Aprovado em: 17 / 03 / 2017

Banca Examinadora

Prof. Dr. Fernando Fagundes Ferreira

Universidade de São Paulo. Escola de Artes, Ciências e Humanidades

Prof. Dr. Roger Chammas

Universidade de São Paulo. Faculdade de Medicina

Prof. Dr. Marcelo da Silva Reis

Instituto Butantan. Laboratório Especial de Ciclo Celular 
Dedico esse trabalho aos meus pais.

Meu pai ensinou-me a buscar incessantemente o conhecimento e a dar valor para a educação. Apresentava-se sempre como o Professor Bartholomeu e até os últimos momentos ele demonstrou essa sede pelo saber. Quando estava para entrar para a derradeira cirurgia da vida dele, perguntou para o médico: - Doutor, eu e meu companheiro professor, lá da casa de repouso, temos uma dúvida: como se dá o transporte de nutrientes da mãe para a placenta, é por osmose?

Minha mãe, a Professora Maria Oneida, ensinou-me a não me dar por vencido e a batalhar com todas minhas forças pelos meus objetivos. Foi agindo assim que conseguiu criar três filhos que depois vieram a se formar cada um em uma universidade pública paulista, todos em cursos de vestibular muito concorrido.

A eles, sempre dedicarei todas as minhas vitórias. 


\section{AGRADECIMENTOS}

Ao meu orientador, professor Alexandre Ferreira Ramos, tenho muito a agradecer pela confiança em minha capacidade de realização deste projeto em uma área tão distante das que eu já havia experimentado, mesmo quando isso exigiu a máxima paciência de sua parte; pelos ensinamentos em setores os mais variados, até de programação, com a apresentação dos dois algoritmos que tornaram tudo possível e, principalmente, pela sua dedicação à ciência, demonstrada pelo trabalho intenso desenvolvido no laboratório $\mathrm{M} 2 \mathrm{C}$ e junto às pessoas que orienta. Não posso esquecer, quando menciono a palavra algoritmo, de agradecer ao Prof. Yuri Suhov, que mostrou novos caminhos a serem trilhados com a apresentação dos seus trabalhos no Brasil.

Agradeço ao professor Roger Chammas, pela acolhida e oportunidades que tem me dado no ICESP e por todas as dicas que direcionaram a biologia e a oncologia do meu trabalho. Agradeço ao maravilhoso e importante ICESP e a todos os pesquisadores e colaboradores deste instituto com quem tenho tido a honra de trabalhar, principalmente, ao Alexandre Sarmento, pela amizade e incentivo constante, em momentos cruciais ou não; pelas aulas de biologia que foram determinantes para o meu engajamento e pelas boas risadas que nos proporcionou com suas tiradas. Não posso deixar de agradecer ao Mauro Morais, também pela orientação, pelos redirecionamentos e conselhos tão úteis em momentos importantes. Ao Tharcísio Tortelli agradeço todas as colaborações e à sua sempre pronta disposição em ajudar.

Todos os professores do programa de mestrado em Modelagem de Sistemas Complexos, com quem tive contato, foram importantes na minha caminhada e merecem meu agradecimento, em especial, gostaria de render graças ao professor Fernando Fagundes, a quem devo o aguçamento pelo gosto nessa magnífica área da ciência e a forte motivação inicial, naquele primeiro semestre de ensinamentos, que me manteve firme nos meus objetivos.

Aos meus colegas de jornada na EACH, o meu muito obrigado. Quero agradecer especialmente ao Sérgio Serino, pela amizade com que me recebeu desde os primeiros instantes, pelas dicas ao colega professor universitário novato e pelos bons papos sobre assuntos diversos, até sobre logística e sistemas complexos, tudo isso foi muito importante para mim. Às colegas Angélica Santana e Misaki Yamada, agradeço a amizade e a preocupação em momentos distintos da minha caminhada, mas de igual importância. A todos do laboratório M2C agradeço a paciência e a atenção nos meus seminários e a todas as colaborações, em especial, sou grato ao meu companheiro de código, o Alan Sabino, pela sua paciência e prontidão em ajudar. Finalmente gostaria de agradecer ao Luiz Guilherme pelo companheirismo desde os primeiros momentos e pela parceria desde aquele nosso trabalho da disciplina de simulação de sistemas complexos.

À minha família deveria ficar horas agradecendo, todas aquelas horas de minha ausência, à distância ou não, e de minha exasperação. A minha amada e maravilhosa esposa, sou grato pelo amor e incentivo incondicional desde os momentos anteriores à minha decisão pela nova carreira escolhida, pelo auxílio forte nas diversas retomadas de rumo que tive que fazer e 
pelas maravilhosas massagens sem as quais não teria aguentado tanto tempo sentado. Ao meu querido filho Guilherme, agradeço todos aqueles momentos de companhia carinhosa e silenciosa contemplando o meu trabalho. À lindinha espevitada, no bom sentido, a Isabella, sou muito agradecido pela força motriz gerada pela sua energia e pelo seu encantamento pela vida. Agradeço aos três pela compreensão das férias sem viagem. Aguardem! A vocês dedico essa alegria que toma conta de mim agora.

À minha mãe, aos meus irmãos, aos parentes e aos amigos agradeço também pela compreensão da minha falta. Dou graças a todos amigos e conhecidos que dedicaram um pouco de seu tempo, sem pedir nada em troca, para torcer por mim e desejar o meu sucesso.

Agradeço à Universidade de São Paulo, mais uma vez, agora em uma nova casa, a querida EACH-USP Leste, pela nova oportunidade de alcançar novos conhecimentos e prometo, como tenho tentado fazer, devolver um pouco deste investimento em minha pessoa para a sociedade.

Enfim, tenho que agradecer de antemão a atenção de você, meu leitor, e desejar que eu consiga acrescentar algo de bom em troca do tempo por você dispendido. Obrigado. 
Aprender é a única coisa de que a mente nunca se cansa, nunca tem medo e nunca se arrepende. Leonardo da Vinci

A tarefa não é tanto ver o que ninguém ainda viu, mas pensar o que ninguém ainda pensou sobre aquilo que todo mundo vê. - Schopenhauer 


\section{RESUMO}

LAUTENSCHLAGER, Willian Wagner. Um modelo estocástico de simulação da dinâmica dos queratinócitos, melanócitos e melanomas no desenvolvimento dos tumores. 2017. $76 \mathrm{f}$. Dissertação (Mestrado em Ciências) - Escola de Artes, Ciências e Humanidades, Universidade de São Paulo, São Paulo, 2017. Versão corrigida.

Durante as últimas décadas, pesquisas em biologia do tumor com a utilização de novas técnicas de biologia molecular produziram informações em profusão, motivando e dando condições para que fossem criados novos modelos matemáticos dedicados à análise de vários aspectos de crescimento e proliferação da população celular. Alguns desses modelos têm sido dedicados à descrição e análise do regime estacionário do processo de desenvolvimento de uma população celular sob condições químicas que se consideram favorecer a aceleração ou desaceleração do crescimento da população de células tumorais. Todavia, a dinâmica temporal do crescimento de uma população de células tumorais ainda não foi analisada nesses trabalhos. Uma das dificuldades é o estabelecimento da interação entre células de múltiplos tipos que sirvam como descrição para essa dinâmica. Nosso trabalho vem preencher essa lacuna e a presente dissertação tem como objetivo a apresentação do modelo, desenvolvido por nós, de simulação da dinâmica do crescimento e proliferação celular do melanoma (câncer de baixa incidência, mas de letalidade extremamente alta) e também dos resultados obtidos através das simulações deste modelo computacional.

\section{Palavras-chave:}

Dinâmica estocástica, modelagem de sistemas, simulação computacional, proliferação celular, câncer, melanoma. 


\begin{abstract}
LAUTENSCHLAGER, Willian Wagner. A stochastic model of simulation of the dynamics of keratinocytes, melanocytes and melanomas in the development of tumors. 2017. $76 \mathrm{p}$. Dissertation (Master of Science) - School of Arts, Sciences and Humanities, University of São Paulo, São Paulo, 2017. Corrected version.

During the last decades, tumor biology research with the use of new techniques in molecular biology resulted in a profusion of information that have given conditions and motivated the development of new mathematical models dedicated to analyzing various aspects of growth and proliferation of the cell population. Some of these models have been devoted to the description and analysis of the steady state of the development process of a cell population under chemical conditions that, in theory, promote the acceleration or deceleration of the growth of tumor cell population. However, these studies have not yet analyzed the temporal dynamics of growth of a tumor cell population. One of the difficulties is the establishment of the interaction between cells of multiple types that serve as the description for this dynamic. Our work fills this gap and this dissertation aims to present the model, developed by us, to simulate the growth dynamics and cellular proliferation of melanoma (cancer of low incidence but of extremely high lethality) and the results obtained through the simulations of this computational model.
\end{abstract}

\title{
Keywords:
}

Stochastic dynamics, system modeling, computational simulation, cell proliferation, cancer, melanoma. 


\section{LISTA DE ILUSTRAÇÕES}

Figura 1 - Camadas da epiderme e suas células características: 1) Camada córnea (mais externa) composta por corneócitos que formas uma barreira hidrofóbica que evita a perda de água pela pele e ainda previne a penetração de substâncias externas que podem ser nocivas; 2) Camada granulosa com células que possuem grânulos repletos de melanina a ser liberada no espaço intercelular à medida da transição para a camada córnea; 3) Camada espinhosa composta por queratinócitos com formatos poliédricos com curtas projeções ligadas às projeções das células vizinhas, o que contribui para a resistência da epiderme ao atrito; 4) Estrato basal ou germinativo (camada mais profunda da epiderme) formado por uma camada única de queratinócitos colunares entremeados por melanócitos e pelas células de Merkel. Nessa camada cerca $30 \%$ dos queratinócitos estão em preparação para a divisão e nesse processo os queratinócitos vão sendo empurrados na direção da superfície passando pelas camadas sobrejacentes, onde o processo de queratinização completa-se (GRAY, 1997 apud TOLEDO, 2012, p. 4). . . . . . . . . . . . . 24

Figura 2 - Esquema de três estágios do movimento celular: 1) A célula estende uma protrusão pela polimerização de actina; 2) Adere a sua borda de ataque à superfície sobre a qual se move e se destaca no corpo da célula e na retaguarda; 3) Puxa todo o corpo celular para frente, por forças contrácteis geradas no corpo celular e na traseira da célula. Adaptado de (KARP, 2005). . . . . . . 30

Figura 3 - Etapas de progressão do melanoma humano (modelo clássico): 1) Nevo formação de um nevo benigno em resposta à exposição à radiação ultravioleta (UV), que não progride devido à senescência celular replicativa; 2) Fase de Crescimento Radial (RGP) - o nevo, depois de ultrapassada a barreira da senescência, torna-se displásico espalhando-se de forma superficial e confinado à epiderme; 3) Fase de Crescimento Vertical (VGP) - as células RGP invadem a derme através da aquisição de capacidade de rompimento da membrana basal; 4) Metástase - as células entram na corrente sanguínea. Adaptado por Silva (2010) de Zaidi, Day e Merlino (2008). . . . . . . . . . 31 
Figura 4 - Regra de restrição à ocupação de um vértice por um determinado tipo de partícula dada a configuração dos vizinhos: $\operatorname{dist}\left(y, y^{\prime}\right)>d(m, n)$, onde a distância dist $\left(y, y^{\prime}\right)$ entre dois vértices $y$ e $y^{\prime}$ é dada pelo menor número de arestas ligando estes vértices e, considerando-se estes dois vértices ocupados, respectivamente, por partículas de tipos $m$ e $n, d(m, n)=d(n, m)$ é o chamado diâmetro de exclusão entre as partículas de tipos $m$ e $n$. Na figura acima o vértice indicado pela seta, só não poderia ser ocupado por uma partícula do tipo 3 , porque $d(3,3)=6$ e a distância entre o vértice do canto superior esquerdo, ocupado por uma partícula do tipo 3, e o vértice assinalado é igual a 3 , ou seja: dist $\left(y, y^{\prime}\right)<d(3,3) \ldots \ldots \ldots \ldots \ldots$

Figura 5 - Dinâmica de ocupação de um domínio bidimensional com três espécies: a) condição inicial, onde o domínio é circundado pelas partículas de tipo 3; b) e c) fases transientes com a formação do domínio por apenas um tipo de partícula; d) estado estacionário com praticamente uma fase, composta predominantemente pelas partículas de tipo 1, com o tipo 3 apenas na região das bordas. . . . . . . . . . . . . . . . . . . . . . 34

Figura 6 - Situações em períodos diversos da simulação com CC3, L = 200, $p_{1}=p_{2}=$ 0,40 e $p_{3}=0,16 \ldots \ldots \ldots \ldots \ldots \ldots$

Figura 7 - Dinâmica da ocupação da simulação com CC3, L $=200, p_{1}=p_{2}=0,40$ e $p_{3}=0,16 \ldots \ldots \ldots \ldots \ldots \ldots \ldots \ldots \ldots \ldots \ldots \ldots \ldots \ldots \ldots \ldots \ldots$

Figura 8 - Situações em períodos diversos da simulação CC3, L $=200, p_{1}=p_{2}=p_{3}=$

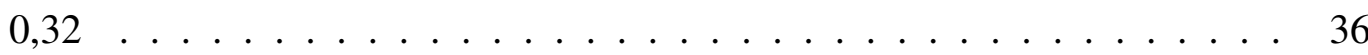

Figura 9 - Dinâmica da ocupação da simulação CC3, $\mathrm{L}=200, p_{1}=p_{2}=p_{3}=0,32$. . 36

Figura 10 - Situações em períodos diversos da simulação CC0, $\mathrm{L}=200, p_{1}=p_{2}=p_{3}=$

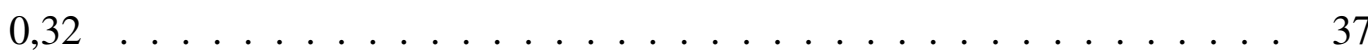

Figura 11 - Dinâmica da ocupação da simulação CC0, L = 200, $p_{1}=p_{2}=p_{3}=0,32 \ldots 37$

Figura 12 - Situações em períodos diversos da simulação $\mathrm{CC} 0, \mathrm{~L}=100, p_{1}=p_{2}=p_{3}=$

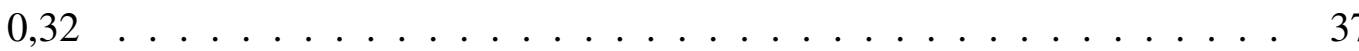

Figura 13 - Dinâmica da ocupação da simulação CC0, $\mathrm{L}=100, p_{1}=p_{2}=p_{3}=0,32 \ldots 38$

Figura 14 - Situações em períodos diversos da simulação CC3, $\mathrm{L}=100, p_{1}=p_{2}=p_{3}=$

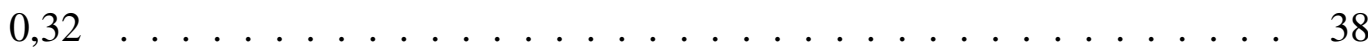

Figura 15 - Dinâmica da ocupação da simulação CC3, $\mathrm{L}=100, p_{1}=p_{2}=p_{3}=0,32$. . 39

Figura 16 - Condições iniciais geradas em três passos de execução do modelo . . . . . . 42

Figura 17 - Mapas de ocupação de simulação do tipo 1 (policlonal) com $\alpha_{1}=0,03$ e

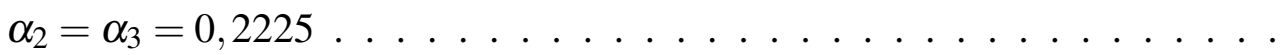

Figura 18 - Dinâmica de ocupação de simulação do tipo 1 (policlonal) com $\alpha_{1}=0,0300$ e $\alpha_{2}=\alpha_{3}=0,2225 \ldots \ldots \ldots \ldots \ldots$

Figura 19 - Mapas de ocupação de simulação do tipo 1 (policlonal) com $\alpha_{1}=0,0350$ e $\alpha_{2}=\alpha_{3}=0,2225 \ldots \ldots \ldots \ldots \ldots \ldots \ldots$ 
Figura 20 - Dinâmica de ocupação de simulação do tipo 1 (policlonal) com $\alpha_{1}=0,0350$

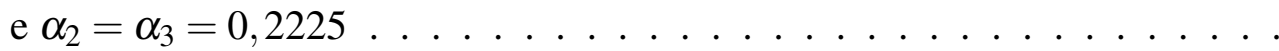

Figura 21 - Mapas de ocupação de simulação do tipo 2 (policlonal) com $\alpha_{1}=\alpha_{3}=$ 0,0200 e $\alpha_{2}=0,2225$

Figura 22 - Dinâmica de ocupação de simulação do tipo 2 (policlonal) com $\alpha_{1}=\alpha_{3}=$ 0,0200 e $\alpha_{2}=0,2225$

Figura 23 - Mapas de ocupação de simulação do tipo 3 (policlonal) com $\alpha_{2}=0,1000$, $\alpha_{1}=\alpha_{3}=0,04$

Figura 24 - Dinâmica de ocupação de simulação do tipo 3 (policlonal) com $\alpha_{2}=0,1000$, $\alpha_{1}=\alpha_{3}=0,0400$.

Figura 25 - Mapas de ocupação de simulação do tipo 3 (policlonal) com $\alpha_{2}=0,2600$, $\alpha_{1}=\alpha_{3}=0,04$

Figura 26 - Dinâmica de ocupação de simulação do tipo 3 (policlonal) com $\alpha_{2}=0,2600$, $\alpha_{1}=\alpha_{3}=0,0400$.

Figura 27 - Mapas de ocupação de simulação do tipo 3 (policlonal) com $\alpha_{2}=0,4000$,

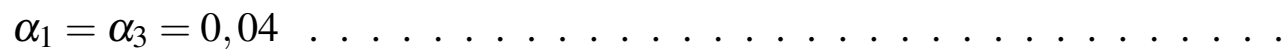

Figura 28 - Dinâmica de ocupação de simulação do tipo 3 (policlonal) com $\alpha_{2}=0,4000$, $\alpha_{1}=\alpha_{3}=0,0400$.

Figura 29 - Mapas de ocupação de simulação do tipo 3 (policlonal) com $\alpha_{2}=0,5000$, $\alpha_{1}=\alpha_{3}=0,04$

Figura 30 - Dinâmica de ocupação de simulação do tipo 3 (policlonal) com $\alpha_{2}=0,5000$, $\alpha_{1}=\alpha_{3}=0,0400$.

Figura 31 - Mapas de ocupação de simulação do tipo 4 (monoclonal) com $\rho_{1}=0,0400$ e $\alpha_{1}=0,4450, \alpha_{2}=0,2225$ e $\alpha_{3}=\alpha_{4}=0,0400$

Figura 32 - Dinâmica de ocupação de simulação do tipo 4 (monoclonal) com $\rho_{1}=$ 0,0400 e $\alpha_{1}=0,4450, \alpha_{2}=0,2225$ e $\alpha_{3}=\alpha_{4}=0,0400$

Figura 33 - Mapas de ocupação de simulação do tipo 4 (monoclonal) com $\rho_{1}=0,2000$ e $\alpha_{1}=0,4450, \alpha_{2}=0,2225$ e $\alpha_{3}=\alpha_{4}=0,0400$

Figura 34 - Dinâmica de ocupação de simulação do tipo 4 (monoclonal) com $\rho_{1}=$ 0,2000 e $\alpha_{1}=0,4450, \alpha_{2}=0,2225$ e $\alpha_{3}=\alpha_{4}=0,0400$

Figura 35 - Mapa e dinâmica de ocupação de simulação do tipo 5 (monoclonal) com $\rho_{1}=4,0 \times 10^{-16}$ e $\alpha_{1}=0,0445, \alpha_{2}=0,2225$ e $\alpha_{3}=\alpha_{4}=0,0400$.

Figura 36 - Mapas de ocupação de simulação do tipo 5 (monoclonal) com $\rho_{1}=0,0$ e $\alpha_{1}=0,0445, \alpha_{2}=0,2225$ e $\alpha_{3}=\alpha_{4}=0,0400 \ldots \ldots \ldots \ldots$

Figura 37 - Dinâmica de ocupação de simulação do tipo 5 (monoclonal) com $\rho_{1}=0,0$ e $\alpha_{1}=0,0445, \alpha_{2}=0,2225$ e $\alpha_{3}=\alpha_{4}=0,0400 \ldots \ldots$. . . . . . 54

Figura 38 - Fluxograma do programa principal do ODyn - pág. 1 . . . . . . . . . 63

Figura 39 - Fluxograma do programa principal do ODyn - pág. 2 . . . . . . . . . . . . 64

Figura 40 - Fluxograma do Procedimento CustGrid - pág. 1 . . . . . . . . . . . . 66

Figura 41 - Fluxograma do Procedimento CustGrid - pág. $2 \ldots \ldots$. . . . . . . . . 67 
Figura 42 - Código do Procedimento UpdateInd . . . . . . . . . . . . . . . . . . 68

Figura 43 - Código do Procedimento DefNeighborhood . . . . . . . . . . . . . . 69

Figura 44 - Código da Função AnNeighborhood - pág. 1 . . . . . . . . . . . . . . . 69

Figura 45 - Código da Função AnNeighborhood - pág. 2 . . . . . . . . . . . . . . . . 70

Figura 46 - Código da Função IndSite . . . . . . . . . . . . . . . . . . . . 70

Figura 47 - Código da Função TransitionE - pág. 1 . . . . . . . . . . . . . . . 71

Figura 48 - Código da Função TransitionE - pág. 2 . . . . . . . . . . . . . . . 72

Figura 49 - Código da Função ReceptorSite . . . . . . . . . . . . . . . . . . . . 72

Figura 50 - Código da Função IndReceptor . . . . . . . . . . . . . . . . . 73

Figura 51 - Código da Função MovReceptorSite . . . . . . . . . . . . . . 73

Figura 52 - Código da Função TransitionO - pág. $1 \ldots$. . . . . . . . . . . . . . 74

Figura 53 - Código da Função TransitionO - pág. 2 . . . . . . . . . . . . . . 75

Figura 54 - Código do trecho do programa principal de decisão sobre o evento de transição 75

Figura 55 - Código do procedimento CalcOcc . . . . . . . . . . . . . 76 


\section{SUMÁRIO}

INTRODUÇÃO . . . . . . . . . . . . . . . . . . 16

1.1 Câncer: uma questão de saúde pública . . . . . . . . . . . . . 16

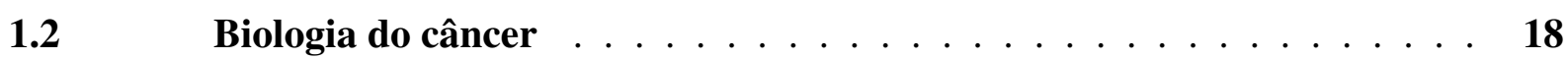

1.3 Objetivos e estrutura da dissertação $\ldots \ldots \ldots \ldots$

2 A BIOLOGIA DA PELE E O MELANOMA . . . . . . . . . . 21

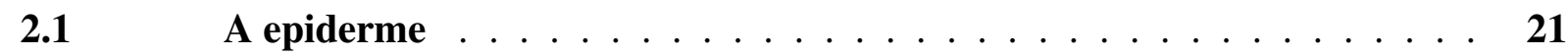

$2.2 \quad$ O câncer . . . . . . . . . . . . . . . . . . 25

2.2.1 Monoclonalidade versus policlonalidade de tumores . . . . . . . . 26

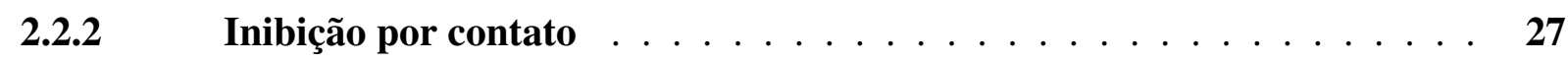

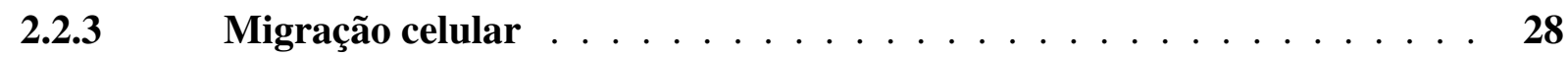

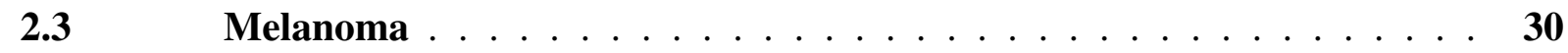

3 UM MODELO ESPACIAL DA DINÂMICA CELULAR ESTOCÁSTICA COM INTERAÇÃO INIBITÓRIA . . . . . . . . . . . . . . 32

$3.1 \quad$ O modelo Widom-Rowlinson . . . . . . . . . . . . . . . 32

3.1.1 Dinâmica de ocupação de um domínio por três espécies . . . . . . . . . . . 33

3.1.2 Simulações ilustrando o domínio pela espécie mais tolerante nas condições estabelecidas pela literatura . . . . . . . . . . . . . . 34

3.1.2.1 Dinâmica de simulação com $C C 3, L=200, p_{1}=p_{2}=0,40$ e $p_{3}=0,16 \ldots \ldots$

3.1.2.2 Dinâmica de simulação com $C C 3, L=200, p_{1}=p_{2}=p_{3}=0,32 \ldots \ldots$

3.1.2.3 Dinâmica de simulação com $C C 0, L=200, p_{1}=p_{2}=p_{3}=0,32 \ldots \ldots$

3.1.2.4 Dinâmica de simulação com $\mathrm{CC} 0, \mathrm{~L}=100, \mathrm{p}_{1}=\mathrm{p}_{2}=\mathrm{p}_{3}=0,32 \ldots \ldots \ldots$

3.1.2.5 Dinâmica de simulação com $C C 3, L=100, p_{1}=p_{2}=p_{3}=0,32 \ldots \ldots 38$

$3.2 \quad$ Um modelo espacial de dinâmica celular estocástica . . . . . . . . . . . . 39

3.2.1 Controle de transição . . . . . . . . . . . . . . . . . . 39

3.2.2 Probabilidades no modelo . . . . . . . . . . . . . . . . 40

3.2.3 A interface gráfica do simulador . . . . . . . . . . . . . . 40

$4 \quad$ RESULTADOS ........................ 42

$4.1 \quad$ Configuração inicial . . . . . . . . . . . . . . 42

4.2 Resultados com melanomas, queratinócitos e com todos melanócitos podendo gerar melanomas (policlonal) . . . . . . . . . . . . . . . . 42

4.2.1 Simulações tipo 1: policlonal com variações de $\alpha_{1}$ e com $\alpha_{2}$ e $\alpha_{3}$ fixos e iguais a $0,2225 \ldots \ldots \ldots \ldots \ldots$

4.2.1.1 Simulação tipo 1: $\alpha_{1}=0,0300 \ldots \ldots \ldots \ldots \ldots$

4.2.1.2 Simulação tipo 1: $\alpha_{1}=0,0350 \ldots \ldots \ldots \ldots \ldots$ 
4.2.2 Simulações tipo 2: policlonal com variações de $\alpha_{1}=\alpha_{3} \operatorname{com} \alpha_{2}$ fixo e igual a $0,2225 \ldots \ldots \ldots \ldots \ldots$

4.2.2.1 Simulação tipo 2: $\alpha_{1}=\alpha_{3}=0,0200 \ldots \ldots \ldots \ldots \ldots \ldots$

4.2.3 Simulações tipo 3: variações de $\alpha_{2} \operatorname{com} \alpha_{1}=\alpha_{3}$ fixos e iguais a $0,0400 \quad$. 45

4.2.3.1 Simulação tipo 3: $\alpha_{2}=0,1000 \ldots \ldots \ldots \ldots \ldots \ldots$

4.2.3.2 Simulação tipo 3: $\alpha_{2}=0,2600 \ldots \ldots \ldots \ldots \ldots \ldots \ldots$

4.2.3.3 Simulação tipo 3: $\alpha_{2}=0,4000 \ldots \ldots \ldots \ldots \ldots \ldots$

4.2.3.4 Simulação tipo 3: $\alpha_{2}=0,5000 \ldots \ldots \ldots$

4.3 Resultados com melanomas, queratinócitos e com apenas um melanócito podendo gerar melanomas (monoclonal) . . . . . . . . . . . . . . . 50

4.3.1 Simulações tipo 4: monoclonal com variações de $\rho_{1}$ com $\alpha_{1}=0,4450$, $\alpha_{2}=0,2225$ e $\alpha_{3}=\alpha_{4}=0,0400$ fixos $\ldots \ldots \ldots \ldots$ 50 . . . . . . . . .

4.3.1.1 Simulação tipo 4: $\rho_{1}=0,0400 \ldots \ldots \ldots \ldots \ldots \ldots$

4.3.1.2 Simulação tipo 4: $\rho_{1}=0,2000 \ldots \ldots \ldots \ldots \ldots \ldots \ldots$

4.3.2 Simulações tipo 5: monoclonal com variações de $\rho_{1}$ com $\alpha_{1}=0,0445$,

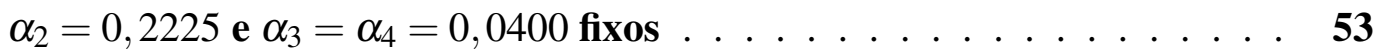

4.3.2.1 Simulação tipo 5: $\rho_{1}=4,0 \times 10^{-16} \ldots \ldots \ldots \ldots \ldots \ldots$

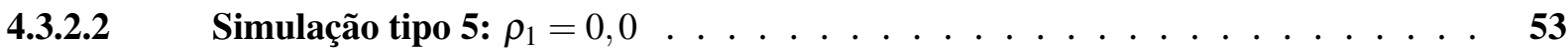

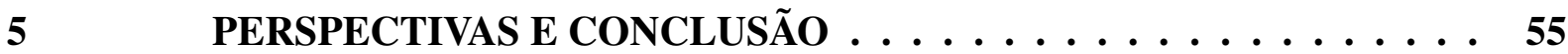

REFERÊNCIAS ...................... 57

ANEXO A - MANUSCRITO DE NOSSA COAUTORIA (AINDA A SER

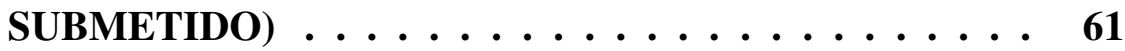

APÊNDICE A - ALGORITMO DO SIMULADOR . . . . . . . 62

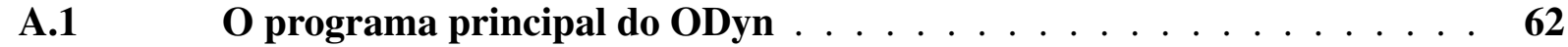

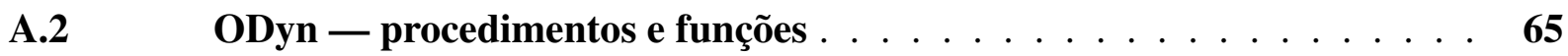

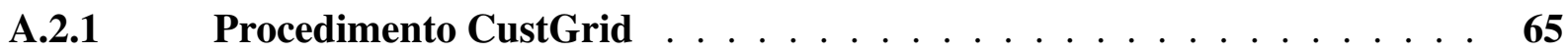

A.2.2 Procedimento UpdateInd . . . . . . . . . . . . . . . . . . 68

A.2.3 Procedimento DefNeighborhood $\ldots \ldots \ldots \ldots$

A.2.3.1 Função AnNeighborhood . . . . . . . . . . . . . . . . . 69

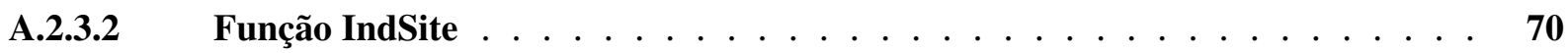

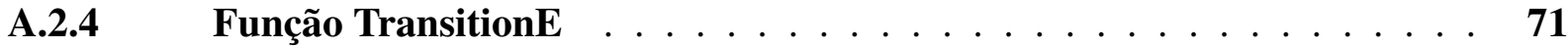

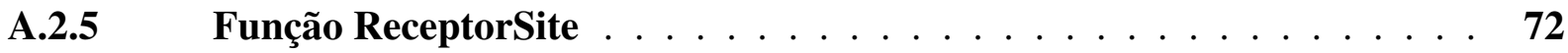

A.2.5.1 Função IndReceptor . . . . . . . . . . . . . . . . 73

A.2.6 Função MovReceptorSite . . . . . . . . . . . . . . . . . 73

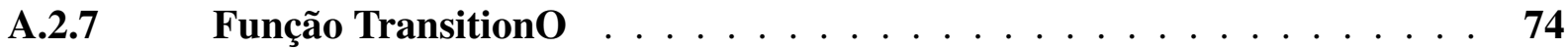

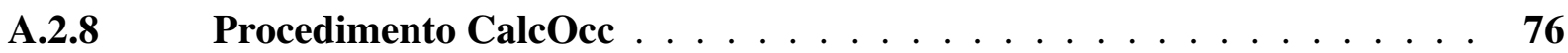




\section{INTRODUÇÃO}

Câncer é um termo genérico que abrange mais de 200 doenças com características comuns, mas extremamente diferentes em termos de origem genética e histopatológica, bem como na progressão da doença, na sua agressividade, no seu prognóstico e na variedade de tratamentos e respostas aos mesmos. Torna-se complexo falar em causa, tratamento e cura do câncer, quando, por vezes, até tumores de um mesmo órgão podem ser diferentes e ter comportamentos distintos (SAITO et al., 2015).

Nesse contexto, os modelos matemáticos tornam-se importantes ferramentas para a compreensão da biologia do câncer e seus aspectos de proliferação celular diferenciada, de aleatoriedade e de sistemas complexos e não-lineares. Os modelos da oncologia matemática podem até orientar o design e a interpretação experimental, por causa da sua exigência de contínua pesquisa interdisciplinar e interativa e também pela sua utilização de dados existentes norteando revisões e buscas por novas informações (GATENBY; MAINI, 2003).

Na primeira seção deste capítulo discutimos o impacto do câncer na saúde pública. Em seguida, apresentamos uma breve descrição da biologia do câncer, do histórico sobre a compreensão dessa doença e sobre o uso de modelos matemáticos como ferramenta adicional ao entendimento dela. Por último apresentamos uma descrição dos objetivos desse trabalho e sua estrutura.

\subsection{Câncer: uma questão de saúde pública}

Com a previsão da International Agency for Research on Cancer (Iarc), da Organização Mundial da Saúde (OMS), de que teremos em 2025 mais de 20 milhões de novos casos de câncer em comparação com os 14 milhões de $2012^{1}$, é inquestionável que o câncer é um sério problema de saúde pública. Esse aumento das neoplasias será devido, principalmente, aos países em desenvolvimento, onde temos, aliados à diminuição da taxa de natalidade e ao aumento da expectativa de vida, ainda a questão dos casos de câncer relacionados à pobreza e, mais recentemente, também à melhoria de condições de vida de parcela da população, que traz no seu bojo, por exemplo, o aumento do consumo do tabaco e álcool (INCA, 2015).

Segundo dados do projeto Globocan da Iarc, em 2012 mais de 60\% dos novos casos ocorreram nos países em desenvolvimento, contribuição que aumenta para $80 \%$ nas estimativas de 2025. Observando-se a mortalidade, os números são ainda maiores, dos 8 milhões de óbitos previstos, $70 \%$ ocorreram nesses mesmos países. Os tipos de câncer com maior incidência global foram os de pulmão (1,8 milhão), de mama (1,7 milhão), de intestino (1,4 milhão) e de próstata (1,1 milhão). Na região da América Latina e do Caribe, ainda com dados de 2012, foram estimados 1,1 milhão $^{1}$ de novos casos de câncer, para os homens o câncer de próstata

\footnotetext{
1 Estes números não levam em conta os casos de câncer de pele não melanoma.
} 
foi o mais frequente com $28,6 \%$ dos casos, seguido pelo de pulmão $(9,8 \%)$, enquanto para as mulheres as estimativas apontaram para $27 \%$ de casos de câncer de mama e de $12,2 \%$ de colo de útero (INCA, 2015).

Podemos observar um perfil da magnitude de determinados tipos de câncer em países em desenvolvimento semelhante àqueles dos países desenvolvidos, isso ocorre nos casos de cânceres de próstata, mama e intestino; porém, ainda observamos casos relacionados com condições socioeconômicas menos favoráveis, como o do colo do útero e o do estômago.

O projeto Globocan estimou, para o biênio 2016-2017, cerca de 600 mil casos novos de câncer no Brasil anualmente (INCA, 2015). O câncer de pele não melanoma é o de maior incidência na maioria das regiões e tem uma estimativa de cerca de 180 mil novos casos, para os outros tipos temos uma distribuição semelhante à da América Latina.

O câncer de pele tipo melanoma não tem uma incidência alta no mundo, da mesma forma no Brasil, onde temos, nessa mesma estimativa do biênio 2016-2017 (INCA, 2015), uma previsão de 5.670 novos casos anuais, 3 mil para homens e 2.670 para mulheres. Entretanto sua letalidade é alta, representa apenas $4 \%$ dos cânceres de pele, mas responde por cerca de $60 \%$ das mortes por este tipo de neoplasia e a incidência de melanoma tem aumentado mais rapidamente do que qualquer outro câncer (SALVIO et al., 2011). No Brasil, onde a base de dados utilizada para mortalidade possui uma defasagem de cerca de dois anos, o número de óbitos em 2013 foi de 1.547, sendo 903 homens e 644 mulheres (INCA, 2016).

Nos Estados Unidos, em 2008, já se verificava, de forma preocupante, o aumento rápido da prevalência de melanoma em mulheres com idade inferior a 40 anos, grupo onde já havia ultrapassado o câncer de mama tornando-se o tumor maligno dominante (ZAIDI; DAY; MERLINO, 2008). De fato, as taxas de melanoma nos EUA dobraram de 1982 a 2011 (AAD, 2016) e a estimativa de 2016 foi de 61.000 novos diagnósticos de carcinoma in situ (não invasivo) da mama feminina contra 68.480 casos de melanoma in situ (ACS, 2016). A estimativa de 2016 era de que 144.860 novos casos de melanoma (76.380 invasivos) seriam diagnosticados nos EUA. Projeções para este país apontavam o melanoma invasivo como o quinto câncer mais comum para homens (46.870 casos) e o sétimo câncer mais comum para mulheres (29.510 casos) em 2016 (AAD, 2016). Na última estimativa mundial de 2012 a previsão era de 232 mil novos diagnósticos de melanoma anuais em todo o mundo. Em termos de mortalidade, a estimativa era de 55 mil óbitos (INCA, 2015).

Cerca de $80 \%$ dos melanomas estão relacionados à radiação ultravioleta devida à exposição solar, outros fatores importantes são a idade, o sexo e a suscetibilidade individual (INCA, 2015). Pessoas com histórico familiar de melanoma também têm um risco aumentado de desenvolvimento deste tipo de câncer. O prognóstico do melanoma pode ser considerado bom se os tumores forem precocemente diagnosticados e tratados de forma adequada, por isso torna-se extremamente importante a educação em saúde para a população, com campanhas de esclarecimento sobre os vários tipos de cânceres de pele, de estímulo à visita periódica ao dermatologista 
e de orientação para a proteção contra a luz solar, uma forma relativamente barata e efetiva de prevenção ao câncer de pele, inclusive ao melanoma (SALVIO et al., 2011).

Devido a seu impacto na saúde pública, é mister investigar o processo de desenvolvimento dos melanomas de maneira a desenvolver técnicas de detecção precoce e estratégias de tratamento mais efetivas. Portanto, nessa dissertação apresentamos uma proposta de modelo dedicado à descrição do desenvolvimento do melanoma.

\subsection{Biologia do câncer}

O organismo animal é composto por conjuntos de células organizados, chamados de tecidos, que exibem um comportamento coletivo coerente destinado a garantir a sobrevivência do animal e distinto de seres unicelulares cujas células podem competir entre si por recursos necessários à sua sobrevivência. Dessa forma, o câncer surge quando uma mutação leva uma dessas células cooperativas a mudar seu comportamento levando-a a uma vantagem competitiva que a faz proliferar de forma anormalmente maior que as células vizinhas e, após ciclos de mutação, de competição e de seleção natural, os descendentes desse clone mutado levam à destruição dessa organização celular. As células cancerosas proliferam de forma desordenada em relação às células normais, escapando das regras que mantêm a inibição normal de crescimento e divisão celular. A ênfase dada à pesquisa do câncer com estudos pormenorizados das regras normais, de seus mecanismos de manutenção e das várias formas que causam o desrespeito a essas regras levou a muitas descobertas na área de biologia celular, além de colaborar para ampliar um conhecimento médico geral (ALBERTS et al., 2015).

Apesar do câncer ser uma doença associada à modernidade, existem registros da doença corretamente diagnosticada há mais de 2.500 anos, como o papiro descoberto pelo egiptologista americano Edwin Smith com registros de casos cirúrgicos de câncer de mama e um outro que descreve o câncer de útero (SAITO et al., 2015). Nesses registros, porém, não são encontrados casos de câncer mais comuns na atualidade, como os de pulmão e dos ossos. Indubitavelmente, o modo de vida da sociedade atual expõe as pessoas a fatores de risco que levam à instabilidade genética e às mutações, que assim aumentam a expressão de oncogenes e o silenciamento de genes supressores de tumor. Somando-se estes fatores ao aumento da longevidade, que dá o tempo necessário para o acúmulo dessas mudanças no genoma, temos uma possibilidade maior de desencadeamento de tumores.

A era pós-genômica possibilitou a geração de uma pletora de dados experimentais sobre a biologia do câncer, o tratamento sistemático desses dados vem fornecendo a compreensão dos fenômenos subjacentes à carcinogênese, como por exemplo o papel da aleatoriedade (TOMASETTI; VOGELSTEIN, 2015). Destarte, continua sendo bem-vinda a introdução de modelos matemáticos que sirvam como ferramentas adicionais à investigação dos processos envolvidos em carcinogênese, como a inibição por contato (HANAHAN; WEINBERG, 2011) ou os fatores estocásticos da metástase. 
De fato, as últimas décadas se caracterizaram pela apresentação de uma grande quantidade de modelos matemáticos destinados à análise de vários aspectos de crescimento e proliferação celular: Gatenby e Frieden (2002), Gatenby e Vincent (2003), Gatenby e Gillies (2004), Gatenby et al. (2006), Gatenby et al. (2007), Gatenby e Frieden (2013), Orlando, Gatenby e Brown (2013), Rietman et al. (2013), Estrella et al. (2013), Hielscher e Wirtz (2013), Liu et al. (2013). Esses modelos aplicam equações de reação-difusão para estudar a dinâmica espacial de formação de domínios celulares quando as células normais e as células cancerosas competem entre si (GATENBY; FRIEDEN, 2002; GATENBY; VINCENT, 2003; GATENBY; GILLIES, 2004). Desenvolvimentos posteriores introduziram a interferência de condições ambientais na dinâmica de competição entre esses dois tipos celulares (GATENBY et al., 2006; GATENBY et al., 2007; SMALLBONE et al., 2007). Os modelos foram dedicados à descrição e análise do regime estacionário do processo de desenvolvimento de uma população celular sob condições químicas que se consideram favorecer a aceleração ou desaceleração do crescimento da população de células tumorais. Em outros trabalhos os resultados numéricos obtidos apresentaram boa concordância com os dados experimentais e foram recebidos com entusiasmo pela comunidade (ESTRELLA et al., 2013; GATENBY; FRIEDEN, 2013; HIELSCHER; WIRTZ, 2013; ORLANDO; GATENBY; BROWN, 2013). Todavia, a dinâmica temporal do crescimento de uma população de células tumorais em que a interação célula-célula inibe a proliferação celular ainda não foi analisada. Uma das dificuldades é o estabelecimento da forma matemática que representa a interação entre células de múltiplos tipos que possa ser utilizada na descrição dessa dinâmica.

Uma das características de populações de células tumorais é a perda desse controle de proliferação que tem a base na interação celular: a chamada inibição por contato (HECKMAN, 2009; HANAHAN; WEINBERG, 2011). A ausência da inibição culmina no crescimento desordenado de um tumor. As células cancerosas ultrapassam o modelo de homeostasia tecidual e, dessa forma, ocupam o espaço de forma descontrolada.

Um modelo apropriado à análise da dinâmica de diferentes tipos de corpos interagindo em um domínio espacial é o modelo de Widom-Rowlinson - WR - (WIDOM; ROWLINSON, 1970), dessa forma, propomos a aplicação desse modelo para investigar a dinâmica estocástica de proliferação celular. No modelo WR múltiplas espécies distintas interagem mutuamente via um potencial repulsivo do tipo "caroço-duro". Elementos de uma mesma espécie exibem afinidade ou, em nossa escala, repulsão mínima. Elementos de espécies distintas se interconvertem e a população, composta por elementos de múltiplas espécies, é governada por um processo de Markov de nascimento e morte. Cada espécie pode ser classificada como um tipo celular saudável ou tumoral. A interação celular, dada em termos de inibição por contato, é considerada máxima nas células saudáveis e mínima (afinidade) nas células tumorais. Isto é, podemos tratar a interação celular via um potencial que é repulsivo e máximo entre células saudáveis, mínimo (afinidade) quando as células tumorais interagem com as saudáveis.

Resultados recentes mostram os modelos WR em que vários tipos de elementos interagem e os tipos dominantes, isto é, aqueles elementos que ocupam maiores áreas no espaço, são 
aqueles que mostram maior tolerância em relação a outros tipos (MAZEL et al., 2014; MAZEL; SUHOV; STUHL, 2015). Isto se dá em decorrência da entropia/energia, implicando que a formação de um domínio espacial (ou "fase") composto por tipos mais tolerantes é mais vantajosa energeticamente (e, portanto, estatisticamente) que qualquer outra. Simulações numéricas confirmam algumas peculiaridades estáveis da dinâmica markoviana de formação da fase dominante, com algumas reversões parciais e deslocamentos espaciais de áreas populadas por diferentes tipos. De toda maneira, a configuração final é que a maior parte do espaço disponível é ocupada pelo tipo mais tolerante.

\subsection{Objetivos e estrutura da dissertação}

A proposta deste trabalho é a de pesquisar a abordagem estocástica na modelagem da dinâmica de ocupação espacial, mais especificamente, para criação de um modelo de proliferação celular e formação tumoral in situ do melanoma cutâneo. Para isso apresentamos, no capítulo 2, uma revisão bibliográfica sobre a pele (2.1) e sobre o câncer (2.2), mostrando alguns aspectos importantes para o enfoque dado ao nosso modelo, como as teorias de monoclonalidade e policlonalidade (2.2.1), a perda da inibição por contato (2.2.2) — uma das características do câncer — e a migração ou motilidade celular (2.2.3). Na parte final desse capítulo apresentamos uma revisão sobre o melanoma cutâneo (2.3). A metodologia principal para a presente modelagem é apresentada no capítulo 3: o modelo Widom-Rowlinson (3.1), bem como o modelo criado para termos a adaptação às condições necessárias para a aplicação na dinâmica de proliferação celular do melanoma (3.2). Finalmente, nos capítulos 4 e 5 são apresentados e discutidos os resultados (capítulo 4) e as perspectivas e conclusões decorrentes do trabalho (capítulo 5). 


\section{A BIOLOGIA DA PELE E O MELANOMA}

A pele é o maior órgão do corpo humano e, por fazer a interface com o ambiente externo, suas funções mais conhecidas são de proteção às intempéries e de defesa imunológica. Porém, a pele é um tecido altamente dinâmico e um órgão com diversas funções complexas. Além de responder a mudanças externas, atua também a partir de alterações internas, funcionando, por exemplo, como termorregulador e controlador da perda de componentes importantes do organismo, principalmente da água. Cobre uma área de cerca de $2 \mathrm{~m}^{2} \mathrm{e}$ pesa em média $4 \mathrm{~kg}$ (WELLER et al., 2008).

Três camadas constituem a pele: a epiderme, a derme e a hipoderme (no sentido da mais externa para a mais interna). A epiderme é firmemente ligada e suportada pela derme, camada subjacente de tecido conjuntivo, tipo tecidual com funções de auxílio na estrutura do corpo como também de conexão entre células e órgãos cujo componente principal é a matriz extracelular (ABRAHAMSOHN, 2008). Esta matriz é composta por filamentos, por um complexo viscoso e hidrofílico - a substância fundamental ou amorfa - que acomoda vasos, nervos e anexos epidérmicos e por diferentes combinações de proteínas fibrosas, cuja proporção define as propriedades do tecido (ABRAHAMSOHN, 2008; STANDRING, 2010). A derme é classificada como um tecido conjuntivo denso, adaptado para oferecer resistência e proteção a outros tecidos por causa de sua matriz extracelular ser composta, predominantemente, por fibras colágenas que chegam a perfazer 70\% da camada (GAWKRODGER; ARDERN-JONES, 2016). A camada dérmica é suprida por uma ampla rede vascular e a epiderme recebe seus nutrientes por contiguidade a esta camada, já que não possui vascularização. Abaixo da derme encontra-se um tecido conjuntivo frouxo, a hipoderme, que normalmente contém gordura abundante. Sua participação no metabolismo energético está relacionada à degradação de ácidos graxos que são produzidos quando as gorduras são quebradas e à prevenção da perda de calor por isolamento térmico (BARBOSA, 2011). Na próxima seção, detalharemos a epiderme, camada de maior interesse para o enfoque do nosso trabalho.

\subsection{A epiderme}

A epiderme é classificada como um epitélio de revestimento. O tecido epitelial é aquele cujas células mantêm muito pouco espaço entre si, estabelecendo muitas junções intercelulares com as células epiteliais vizinhas e com muito pouco material extracelular entre estas células. De acordo com sua localização, arranjo das células constituintes e funções, os tecidos epiteliais podem ser categorizados como de revestimento (função de cobertura da superfície externa ou das diversas cavidades internas do organismo) ou como tecido epitelial secretor ou glandular, especializado em realizar diversos tipos de secreções com várias funções, por exemplo: a síntese de moléculas novas a partir de precursores menores (síntese de proteínas), a modificação de 
moléculas preexistentes ( secreção de esteroides $^{1}$ ) e a secreção para o transporte de íons, como ocorre na secreção do suor e parte da saliva (ABRAHAMSOHN, 2008).

Como a pele, a epiderme também possui camadas ou estratos de células, quatro no total, cada uma com morfologia diferenciada. É composta principalmente por queratinócitos ${ }^{2}$ responsáveis pela sintetização de queratina, proteína que confere impermeabilidade, elasticidade e resistência à pele. Na camada mais externa, os queratinócitos são células planas, semelhantes a lajotas de pavimento, mas com formas irregulares. Os critérios de classificação dos epitélios de revestimento levam em conta o número de camadas de células - simples para uma e estratificado para mais de uma camada - e a forma das células, se o epitélio for estratificado, vale a forma das células da camada mais superficial. Assim, como exemplos, temos o epitélio simples cúbico (uma só camada de células cúbicas ou cubóides) e o epitélio simples prismático (ou colunar) com células altas em formato de prismas ou colunas. Dessa forma, por causa das suas características histológicas, a epiderme é denominada epitélio estratificado pavimentoso queratinizado (ABRAHAMSOHN, 2008; BARBOSA, 2011).

A espessura da epiderme varia de $0,1 \mathrm{~mm}$ (pálpebras) a quase $1 \mathrm{~mm}$ (palmas das mãos e face plantar dos pés) (WELLER et al., 2008). Apesar da descamação constante por abrasão natural das células queratinizadas mortas, essa espessura é mantida regular pelas células em divisão na camada mais profunda (basal ou germinativa). Os queratinócitos, células geradas nesta camada, são empurrados na direção da superfície passando pelas camadas sobrejacentes, a espinhosa e a granular (onde o processo de queratinização completa-se) antes de morrer na camada córnea onde se empilham em cerca de 15 camadas de corneócitos, células mortas achatadas repletas de queratina (BARBOSA, 2011). Na pele normal, aproximadamente 30\% dos queratinócitos basais estão em preparação para divisão, por isso denominado fração de crescimento e, por causa do grande número de células que causam enorme pressão nas suas faces laterais, elas têm o formato de colunas (MONTANARI, 2016). Ainda não existe um consenso para a duração do ciclo celular da pele, com uma variação de estimativas de 50 a 200 h, principalmente devido a dúvidas na primeira fase do ciclo que segue à mitose (chamada G1), onde ocorre sintetização de RNA e proteína, e aumento de tamanho (WELLER et al., 2008).

Os melanócitos ${ }^{3}$ estão presentes na epiderme e nos folículos pilosos da pele humana. $\mathrm{Na}$ epiderme, estão localizados na camada basal, onde, independentemente da cor da pele, existem cerca de 1200 melanócitos para cada $\mathrm{mm}^{2}$ da sua área e em uma proporção de 1:10 queratinócitos (CICHOREK et al., 2013). Os melanócitos maduros são células menores que os queratinócitos,

${ }^{1}$ Esteroide - composto com papel estrutural, metabólico e hormonal como o colesterol, a cortisona, a progesterona e a testosterona. (HOUAISS, 2017)

2 "Queratinócito - do grego Kerat, de textura córnea, e In, substância e Kytos, célula. A célula mais frequente da epiderme que sintetiza queratina." (SIMõES et al., 2014, 78)

3 "Melanócito - do grego Melas, negro e Kytos, célula. O melanócito é uma célula neuro-cutânea ( sic) que surge a partir da crista neural no período embrionário. Produz melanina, substância pigmentar que envolve a célula protegendo seu núcleo dos raios solares." Ibid., p. 55. 
têm formato oval ou fusiforme ${ }^{4}$ e possuem dendritos ${ }^{5}$, através destes, cada melanócito tem contato com 30 a 40 queratinócitos para a transferência da melanina, pigmento que é produzido pelo próprio melanócito e fornece fotoproteção às células da pele e também determina a sua cor. Os melanócitos têm origem nas células da crista neural (NCC), porém, existem outras células produtoras de melanina com origem embrionária diferente, por exemplo, as do epitélio pigmentado da retina. Apesar de sua origem comum e de todos sintetizarem melanina, os melanócitos assumem funções específicas conforme a sua localização no corpo humano. Além da presença na epiderme, no cabelo e na íris, onde os melanócitos lhes conferem cor, também estão presentes em diversos locais como, por exemplo, no ouvido interno, no sistema nervoso e no coração. No adulto, há células-tronco dos melanócitos nos folículos pilosos e os melanócitos são capazes de se dividir (MONTANARI, 2016).

Na figura 1 (GRAY, 1997 apud TOLEDO, 2012, p. 4) ${ }^{6}$, apresentamos um esquema das quatro camadas da epiderme, cada qual com uma configuração diferenciada que denota suas funções. A mais externa é chamada camada córnea e, através das suas células denominadas corneócitos, forma uma barreira hidrofóbica que evita a perda de água pela pele e ainda previne a penetração de substâncias externas que podem ser nocivas. A camada granulosa está localizada entre as camadas córnea (acima) e espinhosa (abaixo), tem esse nome porque suas células possuem grânulos repletos de substâncias que serão liberadas no espaço intercelular na medida que sofrerem transição para a camada córnea, o que formará a barreira semipermeável da camada superior. Logo abaixo da camada granulosa encontra-se a camada espinhosa composta por queratinócitos com formatos poliédricos, porque a pressão nas suas laterais é menor e mais uniforme. Nessa camada as células possuem curtas projeções ligadas às projeções das células vizinhas por desmossomos ${ }^{7}$, o que contribui para a resistência da epiderme ao atrito. Esta camada é chamada de espinhosa porque, no corte histológico, essas ligações intercelulares assemelham-se a espinhos (MONTANARI, 2016). A camada mais profunda da epiderme, o estrato basal, é formado por uma camada única de células colunares, os queratinócitos, entremeados pelos melanócitos e pelas células de Merkel que se diferenciam, como os melanócitos, na vida intrauterina a partir das células da crista neural. As células de Merkel são células semelhantes aos melanócitos quando observadas com microscópio de luz, mas ocorrem em menor número e são mais difíceis de serem observadas. Como atuam como receptores táteis têm junções sinápticas com terminações nervosas sensitivas (MONTANARI, 2016). A estrutura dessa camada é estabelecida pelos hemidesmossomos ${ }^{8}$ — que fixam a epiderme na membrana basal — e pelos

4 "fusiforme [...] que tem forma de fuso, mais espesso ao centro e atenuando-se em direção às extremidades [...]" (HOUAISS, 2017)

5 "Dendrito - do grego Déndron, árvore. Na histologia representam as ramificações citoplasmáticas [...] que partem do corpo da célula. [...]". (SIMõES et al., 2014, 28)

${ }^{6}$ GRAY, J. The world of skin care. [S.1.]: Procter \& Gamble Skin Care Research Center, 1997.

7 "Desmossoma - do grego Desmo, atadura, ligamento e Soma, corpo, corpúsculo. Espessamento especializado da membrana celular de algumas células que serve para fixá-las às células adjacentes." SIMõES et al., 2014, loc. cit.

8 "Hemidesmossoma - do grego Hemi, metade e Desmo, que une, ligadura e Soma, corpo. Junção celular especializada geralmente entre uma célula epitelial e a membrana basal subjacente; morfologicamente se parece 
desmossomos que nessa camada também têm a função de manter os queratinócitos juntos.

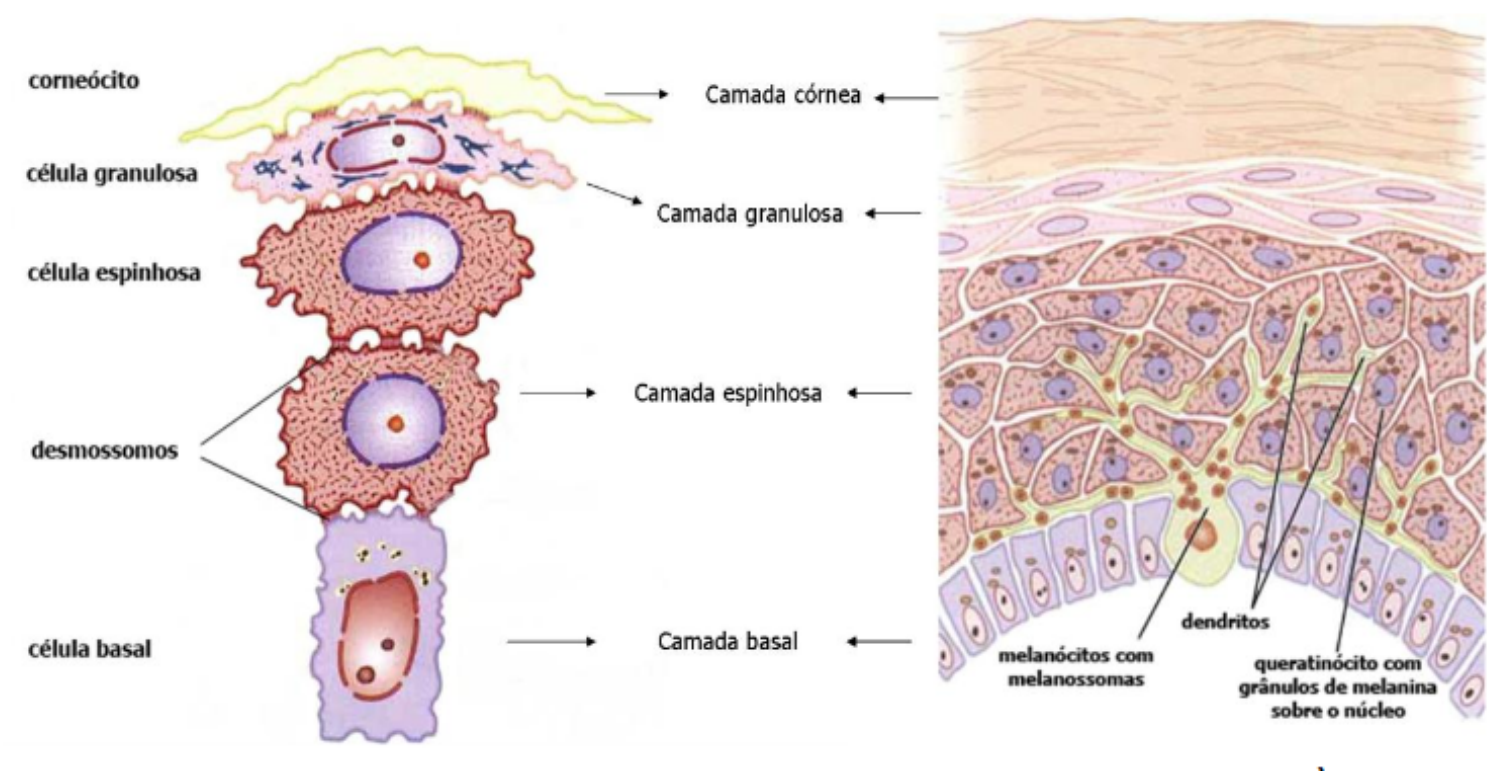

Figura 1 - Camadas da epiderme e suas células características: 1) Camada córnea (mais externa) composta por corneócitos que formas uma barreira hidrofóbica que evita a perda de água pela pele e ainda previne a penetração de substâncias externas que podem ser nocivas; 2) Camada granulosa com células que possuem grânulos repletos de melanina a ser liberada no espaço intercelular à medida da transição para a camada córnea; 3) Camada espinhosa composta por queratinócitos com formatos poliédricos com curtas projeções ligadas às projeções das células vizinhas, o que contribui para a resistência da epiderme ao atrito; 4) Estrato basal ou germinativo (camada mais profunda da epiderme) formado por uma camada única de queratinócitos colunares entremeados por melanócitos e pelas células de Merkel. Nessa camada cerca 30\% dos queratinócitos estão em preparação para a divisão e nesse processo os queratinócitos vão sendo empurrados na direção da superfície passando pelas camadas sobrejacentes, onde o processo de queratinização completa-se (GRAY, 1997 apud TOLEDO, 2012, p. 4).

O mecanismo de controle da epiderme de estabelecimento da organização e da proporção de melanócitos em relação aos queratinócitos ainda não foi completamente elucidado. Sabe-se que se comunicam, entre eles e também com os fibroblastos ${ }^{9}$ dérmicos, através de fatores secretados e pelos contatos célula-célula. Os melanócitos e queratinócitos são produtores locais de diversos hormônios que ajudam no controle da proliferação dos próprios melanócitos, da produção de melanina e da formação dendrítica. A maioria dos fatores parácrinos ${ }^{10}$ é secretada pelos queratinócitos após exposição à radiação UV. Também colaboram para a biologia

com a metade de um desmossoma." (SIMõES et al., 2014, 43)

9 "Fibroblasto - do latim, Fibros, fibras e Blastos, germe, formador. Nome dado às células do tecido conjuntivo responsáveis pela síntese da matriz extracelular, em especial das fibras colágenas e elásticas. Secretam também glicosaminoglicanos, proteoglicanos e glicoproteínas multiadesivas. São células fusiformes que possuem inúmeros prolongamentos com núcleo grande, ovóide, com cromatina fina e nucléolo evidente." Ibid., p. 38.

10 "Parácrino - do grego Para, ao lado de e Krin, secreção. É uma substância ou célula cuja secreção afeta as células vizinhas." Ibid., p. 68. 
dos melanócitos, fatores secretados por fibroblastos dérmicos, como, por exemplo, o fator de células estaminais (SCF) e a neuregulina 1 (NRG1). Estas citocinas ${ }^{11}$ influenciam, além das propriedades já citadas, também as de mobilidade e adesão. Os melanócitos nessas unidades de melanina epidérmica também agem ativamente na produção de moléculas de sinalização não só para queratinócitos, mas também às células do sistema imunológico na pele. Desse modo, os melanócitos e queratinócitos em cooperação formam uma unidade organizada na epiderme, onde o elemento mais estável é o melanócito que vive muito tempo (quanto tempo ele vive na pele humana ainda é uma questão em aberto). Os queratinócitos morrem e são eliminados por descamação. (CICHOREK et al., 2013).

\subsection{O câncer}

O avanço no conhecimento dos mecanismos de formação do câncer tanto no nível celular quanto no molecular, permitiu que se começasse a avançar na pesquisa dos aspectos mais complexos de formação de tumores no próximo nível de organização, o tecidual. Essa compreensão é importante porque as características biológicas do câncer dependem do local onde surgiu o tumor. O câncer surge com o acúmulo de alterações genéticas, que vão gradualmente liberando as células do normal mecanismo equilibrado de proliferação. Estudos em modelos animais, análises de alterações genéticas presentes em séries de biópsias (VOGELSTEIN et al., 1988 apud HAHN; WEINBERG, 2002b) ${ }^{12}$, além de análises epidemiológicas da incidência com que tipos específicos de câncer aparecem na população humana em função da idade, têm mostrado que devem ocorrer quatro a seis eventos definidores dos passos necessários - eventos considerados como mutações distintas - para o tumor se tornar clinicamente aparente (HAHN; WEINBERG, 2002a; HAHN; WEINBERG, 2002b).

A função dos tecidos normais depende da estabilidade de uma complexa rede de interação de moléculas que controlam os circuitos de regulação intracelular e intercelular. Essa estrutura dos tecidos e sua integridade funcional é assegurada por uma organização compartimental (MINTZ, 1970 apud SOLÉ; GARCÍA; COSTA, 2006, p. 558) ${ }^{13}$. Cada um desses compartimentos de células diferenciadas é mantido por um grupo de células-tronco que garante a autorrenovação e mantém a proliferação nos níveis adequados. O sistema do tecido como um todo funciona em um nível de atividade contínuo e estável que mantém as proporções de cada elemento constitutivo constantes. Assim, em condições normais, a concorrência entre as células é evitada e esses compartimentos de células clonais só aumentam de tamanho quando um clone vizinho falha e

11 "Citocina - do grego Kyto, célula e In(a) substância química. Qualquer proteína inmunorreguladora (sic) como a interleucina, o interferon, secretadas pelas células do sistema imunitário, generalmente (sic) fagocíticas." Ibid., p. 21.

${ }^{12}$ VOGELSTEIN, Bert et al. Genetic alterations during colorectal-tumor development. New England Journal of Medicine, v. 319, n. 9, p. 525-532, 1988.

${ }^{13}$ MINTZ, B. Clonal basis of mammalian differentiation. In: Symposia of the Society for Experimental Biology. Cambridge, United Kingdom: Cambridge University Press for the Society for Experimental Biology, 1970. v. 25, p. 345-370. 
desaparece. De forma oposta, o surgimento de um tumor e seu crescimento pode ser entendido como um processo microevolutivo em que as mudanças ocorrem de várias formas gerando uma heterogeneidade que colabora com a emergência de um clone bem-sucedido de células. Dois modelos diferentes podem explicar as mutações. No primeiro modelo tem-se uma baixa taxa de mutação em uma população muito grande. No outro, uma alta taxa de mutação em uma população limitada leva à geração de populações de células tumorais com um conjunto heterogêneo de propriedades, isto em um período relativamente curto de tempo. É provável que o processo de desenvolvimento do câncer combine esses dois tipos de relação das taxas de mutação com o tamanho da população. As mutações iniciais ocorrem com taxas baixas em uma população grande gerando clones de expansão. Dentro de um destes clones ocorre, eventualmente, uma mutação que leva a um fenótipo ${ }^{14}$ com alta taxa de mutação e, assim, rapidamente células com vantagens de sobrevivência são selecionadas gerando fenótipos com grande capacidade vital. (PIENTA, 2006; SOLÉ; GARCÍA; COSTA, 2006).

Em um ponto de vista de populacional, os eventos de mutação favorecem dois processos, o da concorrência entre diferentes clones e o da expansão daqueles com taxas de crescimento maiores. Dadas duas populações distintas, a coexistência será permitida apenas se a concorrência entre elas for baixa, senão, uma das populações prevalecerá. Em outras palavras, se não houver um ajuste da concorrência que evite a exclusão competitiva, a população tenderá para a homogeneidade. Porém, com novos avanços na área de ecologia espacial, sugere-se que a heterogeneidade pode ser um resultado final, em condições de espaço propícias, muito mais comum que aquele previsto na teoria de competição (SOLÉ; GARCÍA; COSTA, 2006). Analogamente, o câncer era visto como uma massa homogênea com capacidade de rápida proliferação, mas descobriu-se que as células tumorais eram heterogêneas em relação à proliferação e também à diferenciação. Em alguns tipos de tumores foram encontradas pequenas populações de células capazes de iniciar e manter um nível mais alto de proliferação, além de propiciar heterogeneidade através da origem de vários tipos de células proliferativas e diferenciadas que compõem a massa tumoral, as chamadas células-tronco tumorais ou cancer stem cells - CSCs (SILVA, 2010).

\subsubsection{Monoclonalidade versus policlonalidade de tumores}

Mesmo com a aceitação da ideia sobre a liberação gradual das células do equilíbrio normal de proliferação através do acúmulo progressivo de alterações genéticas, ainda fica a questão sobre a origem da massa tumoral. Em tese, as células do tumor podem descender de uma única célula que sofreu alterações não deletérias, ou isso pode ter acontecido com uma série de células, onde, cada uma delas se tornou ancestral de uma subpopulação distinta dessa massa tumoral. Quando um tumor deriva de uma célula ancestral, por exemplo, onde se pode

\footnotetext{
14 "Fenótipo - do grego Phain, mostra-se (sic) [mostrar-se e] Typ(o), forma. Realização visível do genótipo em um determinado ambiente." (SIMõES et al., 2014, 38).

"Genótipo - do grego Genos, raça e Typos, impressão. É a constituição genética interna ou hereditária de um organismo sem levar em conta seu aspecto externo." Ibid., p. 41.
} 
encontrar um mesmo marcador genético incomum presente em todas suas células, é dito que a população desse tumor é monoclonal. Por outro lado, se o tumor é formado por uma série de subpopulações distintas, que não fornecem nenhum indício de uma origem comum, essas subpopulações formam uma massa tumoral que é considerada policlonal.

Há um consenso, bem estabelecido, de que a maioria dos tumores humanos são monoclonais. Isto começou a ser firmado em 1965, quando observações de tumores benignos da parede uterina (leiomiomas) em afro-americanas heterozigotas (com alelos diferentes de um determinado gene) mostraram um incomum padrão de inativação de cromossomos herdados ou do pai ou da mãe, quando o normal seria ter os dois tipos de inativação, já que isso ocorre de forma aleatória ainda na fase embrionária e as células descendentes continuam a inativar o mesmo cromossomo em um adulto. Isto demonstrou, com uma probabilidade alta, que todas as células componentes desses tumores tinham uma origem comum. Outras demonstrações seguiram essa pioneira, como no caso do mieloma - câncer nas células plasmáticas, que são células produtoras de anticorpos. Normalmente temos centenas de milhares de populações distintas dessas células, cada qual produzindo um tipo de anticorpo, mas no mieloma observa-se a produção de um tipo específico de anticorpo, indicando sua ascendência de um único tipo ancestral que estava presente naquela população heterogênea original (WEINBERG, 2016).

Apesar dessas provas, uma teoria policlonal também tem lugar, porque se tivéssemos uma série de células ultrapassando a barreira da normalidade em momentos distintos, mas próximos, poderíamos, dado o tempo de desenvolvimento de tumores que pode chegar a décadas, ter o aparecimento da dominância de um grupo de células descendentes de apenas uma daquelas que sofreram a alteração no início. Assim, teríamos a aparência de uma origem estritamente monoclonal, quando na realidade não era o que havia acontecido desde o início (WEINBERG, 2016).

\subsubsection{Inibição por contato}

O conceito da inibição por contato relacionado à motilidade celular foi introduzido nos anos 1950 e nos 1960 por Abercrombie e Heaysman. Na época, foram feitos experimentos, baseados em medições cuidadosas e análise estatística, utilizando-se dois explantes de coração de pintinho colocados a menos de um milímetro de distância sobre uma lamela de vidro. À medida que as células entravam em contato a taxa de migração sofria um declínio acentuado, diferentemente daquelas que migravam afastando-se dos explantes, onde esse movimento mantinha um ritmo constante (ABERCROMBIE; HEAYSMAN, 1953 apud HECKMAN, 2009, p. 574) ${ }^{15}$. As células não se acumulavam na região de contato como era de se esperar e, ao invés disso, migravam para o espaço livre ao redor (ABERCROMBIE; HEAYSMAN, 1954 apud HECKMAN, 2009,

\footnotetext{
${ }^{15}$ ABERCROMBIE, Michael; HEAYSMAN, Joan EM. Observations on the social behaviour of cells in tissue culture: I. Speed of movement of chick heart fibroblasts in relation to their mutual contacts. Experimental cell research, Elsevier, v. 5, n. 1, p. 111-131, 1953.
} 
p. 574) ${ }^{16}$. Com o complemento de observações microscópicas foram descobertas duas regras de comportamento que governam o fenômeno de inibição por contato. A primeira delas foi a de que as células não aderem sobre as superfícies superiores de outras células, nas experiências somente migraram e aderiram sobre o vidro. A outra regra definiu que duas células que fazem contato em seus bordos de ataque cessam sua motilidade naquele segmento em que se tocaram através da parada das ondulações (veja a seção 2.2.3 abaixo sobre esses conceitos).

A inibição por contato foi definida como um mecanismo, comprovado em quatro décadas de pesquisa em culturas bidimensionais, onde o contato célula-célula, em densas populações, opera para diminuir a proliferação celular resultando em monocamadas de células confluentes (HANAHAN; WEINBERG, 2011). De forma importante também, em vários tipos de culturas de células cancerosas foi provada a supressão desse mecanismo. Dessa maneira, sugerindo que a "inibição por contato" é um similar substituto in vitro de um mecanismo in vivo que assegura o equilíbrio dinâmico (homeostase) dos tecidos normais, revogado no curso da formação do tumor. Até recentemente não eram conhecidas as formas como esse mecanismo era desencadeado, porém, agora, esse modo de controle de crescimento começou a sair da obscuridade com algumas descobertas. Um destes mecanismos envolve o produto de um reconhecido supressor de tumor que é o gene NF2, denominado neurofibromina 2 ou merlin, pertencente a uma família de proteínas de membranas associadas ao citoesqueleto (KUMAR; ASTER; ABBAS, 2015). A proteína merlin faz a orquestração da inibição por contato através do acoplamento de moléculas de adesão da superfície celular (por exemplo, E-caderina) às receptoras transmembranares (por exemplo, o receptor EGF) reforçando a adesão dos anexos célula-célula mediada por caderina (HANAHAN; WEINBERG, 2011). Um segundo mecanismo de inibição por contato envolve a proteína LKB1 de tecidos de revestimento (tecidos epiteliais) que é responsável por organizar a estrutura do epitélio e manter a integridade do tecido. Quando a expressão dessa proteína é suprimida a integridade epitelial perde a estabilidade e as células epiteliais tornam-se suscetíveis às transformações induzidas por genes relacionados com o surgimento de tumores, os chamados oncogenes. Ainda é matéria de pesquisa a frequência com que esses fatores de supressão de crescimento por contato estão comprometidos nos cânceres, mas claramente representam um importante meio de suprimir e contrabalançar sinais inadequados de proliferação (HANAHAN; WEINBERG, 2011).

\subsubsection{Migração celular}

A migração ou motilidade celular é um fenômeno dinâmico que se relaciona com vasta gama de processos biológicos, por exemplo, desenvolvimento morfológico do organismo (morfogênese), cicatrização de ferimentos e metástases do câncer. Por exemplo, na morfogênese as células em divisão são direcionadas para os locais específicos de formação de órgãos e tecidos. Similarmente, para ocorrer a recuperação de um tecido ferido, as células de glóbulos brancos

\footnotetext{
${ }^{16}$ ABERCROMBIE, Michael; HEAYSMAN, Joan EM. Observations on the social behaviour of cells in tissue culture: II. "Monolayering” of fibroblasts. Experimental cell research, v. 6, n. 2, p. 293-306, 1954.
} 
(neutrófilos) e os macrófagos (células que ingerem bactérias) devem ir até o local da ferida para matar os microrganismos causadores da infecção e os fibroblastos, que são células do tecido conjuntivo, então, tem de se mover até lá para remodelar a estrutura danificada. Nesses exemplos e na maioria dos casos, as células se movem por rastejamento, mas existem outras formas de movimento como a da maior parte das células espermáticas que ocorre por natação e a do movimento de rotação flagelar de algumas bactérias. (ANANTHAKRISHNAN; EHRLICHER, 2007).

Da mesma forma que o esqueleto dos vertebrados, que dá suporte aos tecidos moles do organismo e permite os movimentos corporais, as células dos eucariotas também possuem um sistema estrutural - o citoesqueleto - responsável por funções semelhantes, como o suporte estrutural da célula, o posicionamento e transporte de várias organelas no interior das células, além de também compor os elementos que geram a força necessária para a movimentação celular de um ponto a outro. O citoesqueleto é composto por três tipos de estruturas fibrosas que auxiliam nessas e outras atividades celulares: microtúbulos, filamentos intermediários e os microfilamentos de actina (KARP, 2005). Essas estruturas são biopolímeros (polímeros encontrados em organismos vivos, como DNA, RNA e proteínas) diferenciados pela sua rigidez. (ANANTHAKRISHNAN; EHRLICHER, 2007). Os microtúbulos são polímeros dinâmicos sujeitos a encurtamento e alongamento, a despolimerização e repolimerização. São estruturas cilíndricas e ocas com $25 \mathrm{~nm}$ de diâmetro e devido à sua rigidez têm função frequente de sustentação. Os filamentos intermediários são estruturas semelhantes a cordas com $10 \mathrm{~nm}$ de diâmetro, são responsáveis pela estabilidade mecânica por causa da sua resistência às forças de tensão e relativa insolubilidade e também suportam funções específicas dependentes de cada tecido. Os filamentos de actina, também conhecidos como microfilamentos, têm função muito importante em todos os tipos de motilidade celular e de contratibilidade - propriedades das células de reduzir as dimensões mediante estímulo. Esses filamentos podem ser organizados de forma mais rígida ou mais frouxa conforme o tipo e a atividade celular (KARP, 2005).

Na figura 2, abaixo, é apresentado um esquema dos três estágios do movimento celular, adaptado de (KARP, 2005): depois de determinar sua direção de movimento, a célula estende uma protrusão nessa direção pela polimerização de actina na borda de ataque. Em seguida, adere a sua borda de ataque à superfície sobre a qual se move e se destaca no corpo da célula e na retaguarda. Finalmente, puxa todo o corpo celular para frente, por forças contrácteis geradas no corpo celular e na traseira da célula.

Uma forma de motilidade celular é aquela gerada por um feixe de filamentos de actina em estresse com uma distribuição que gere tensão entre as células e o substrato, presumivelmente, por geração de contrações isométricas. Uma célula deslizando geralmente achata-se e gera projeções em forma de véu na extremidade da célula, os lamelipódios. À medida que esse lamelipódio estende-se a partir da célula, vai aderindo em pontos específicos do substrato abaixo, fornecendo pontos de ancoragem temporários para que a célula vá deslizando sobre o mesmo. As forças de protrusão do lamelipódio são fornecidas pela polimerização dos filamentos de actina e pela combinação destes com várias proteínas ligantes à actina (KARP, 2005). 


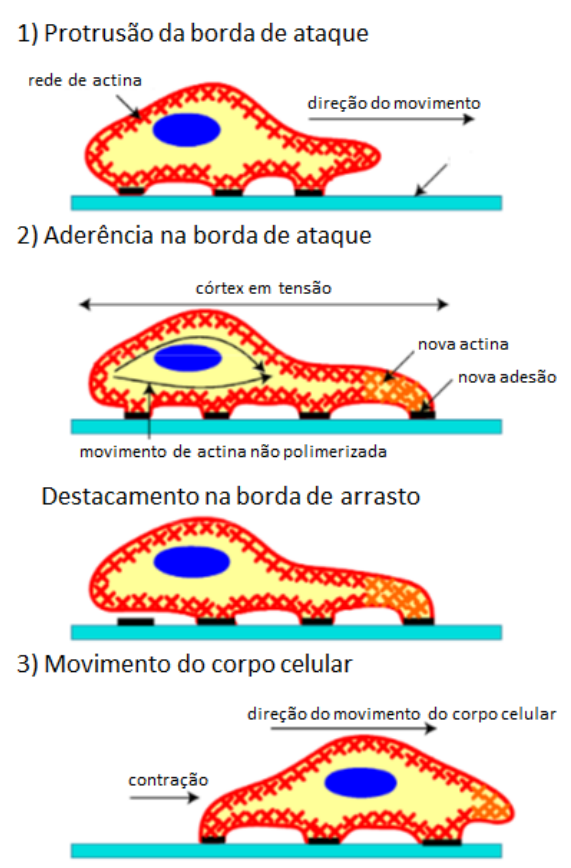

Figura 2 - Esquema de três estágios do movimento celular: 1) A célula estende uma protrusão pela polimerização de actina; 2) Adere a sua borda de ataque à superfície sobre a qual se move e se destaca no corpo da célula e na retaguarda; 3) Puxa todo o corpo celular para frente, por forças contrácteis geradas no corpo celular e na traseira da célula. Adaptado de (KARP, 2005).

\subsection{Melanoma}

O principal agente etiológico do melanoma, o espectro de radiação solar UV, é conhecido e estudado há mais de 50 anos (SOUZA; FISCHER; SOUZA, 2004) e os diferentes estados de doença, de nevo benigno a melanoma primário metastático, são visíveis e extirpáveis. Porém, apesar desses fatos fazerem com que o melanoma seja altamente passível de análise molecular, ainda não são adequadamente conhecidos os mecanismos pelos quais a luz solar inicia o melanoma e pelos quais as células atingem a capacidade de enviar metástases. Essa questão é devida, em parte, às limitações na aquisição de tecidos para estudo, porque as lesões melanocíticas humanas são sistematicamente arquivadas para posterior análise e também pela falta de modelos animais experimentais relevantes para o caso do melanoma humano (ZAIDI; DAY; MERLINO, 2008). Ademais, a física da interação entre a radiação e a matéria viva é um campo de pesquisa em aberto. Dessa forma, tornam-se ainda mais importantes os modelos efetivos dedicados à descrição da gênese do melanoma em suas fases inicias que permitam ampliar o conhecimento acerca desses estágios críticos.

O modelo clássico de desenvolvimento do melanoma tem quatro fases, na figura 3 , adaptada por Silva (2010) de Zaidi, Day e Merlino (2008), é apresentado um esquema representando estas etapas de progressão do melanoma humano e as alterações moleculares que lhes dão origem e colaboram com sua progressão. O desenvolvimento começa com a formação de um nevo benigno - uma população de melanócitos que cresceram de maneira desorganizada 
formando uma lesão pelo excesso de células no local (lesão hiperplásica) — geralmente em resposta à exposição à radiação ultravioleta (UV), mas que não progride devido à senescência celular replicativa ${ }^{17}$. Em uma segunda fase proliferativa, depois de ultrapassada essa barreira natural da senescência, este nevo torna-se displásico, isto é, uma lesão no nível tecidual, podendo espalhar-se de forma superficial ainda confinado à epiderme e com baixo poder invasivo. É a chamada Fase de Crescimento Radial (RGP). As ditas células RGP, podem vir a invadir a derme através da aquisição de capacidade de rompimento da membrana basal ingressando na Fase de Crescimento Vertical (VGP) que formam metástases. Dados clínicos apontam que nem todos os melanomas seguem esse processo, porque foram observados casos de metástases sem evidências de lesão primária (ZAIDI; DAY; MERLINO, 2008).

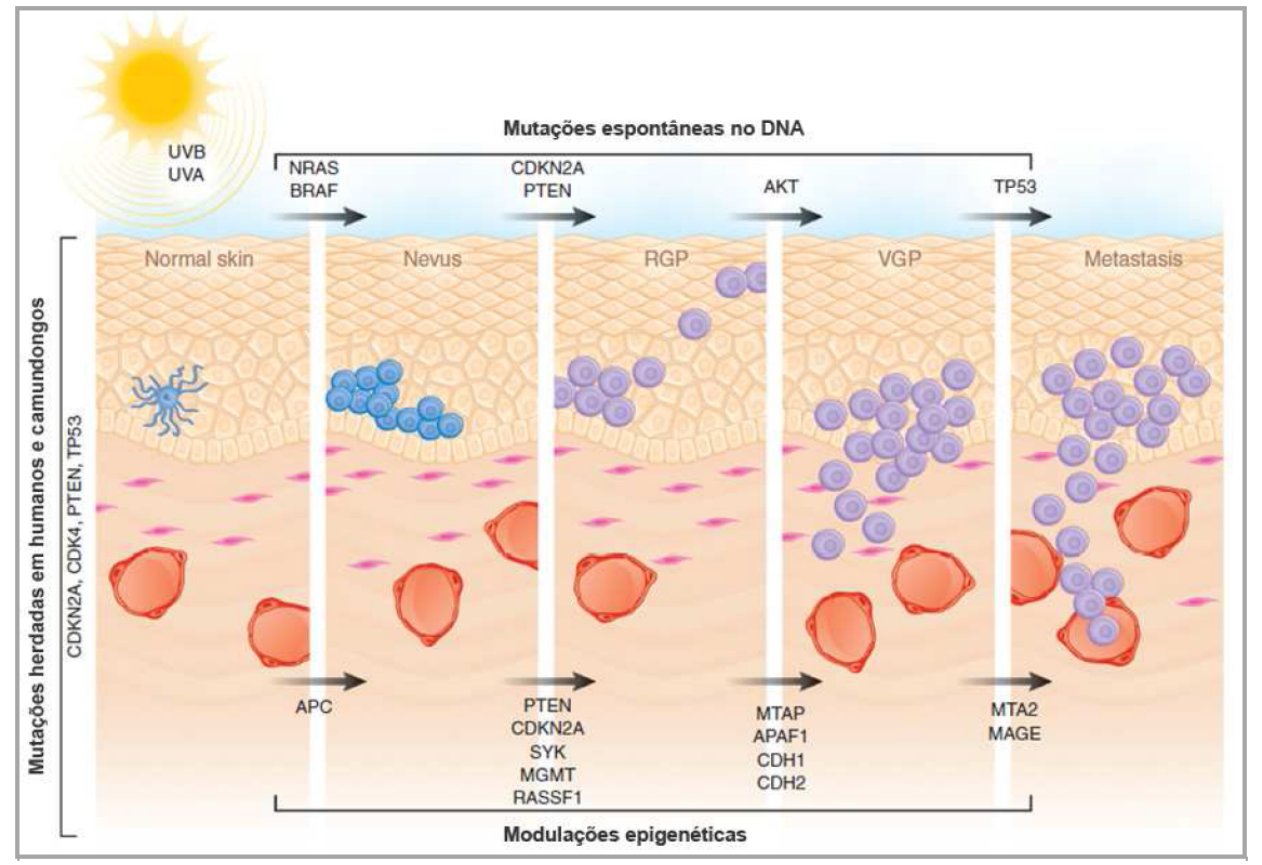

Figura 3 - Etapas de progressão do melanoma humano (modelo clássico): 1) Nevo - formação de um nevo benigno em resposta à exposição à radiação ultravioleta (UV), que não progride devido à senescência celular replicativa; 2) Fase de Crescimento Radial (RGP) - o nevo, depois de ultrapassada a barreira da senescência, torna-se displásico espalhando-se de forma superficial e confinado à epiderme; 3) Fase de Crescimento Vertical (VGP) - as células RGP invadem a derme através da aquisição de capacidade de rompimento da membrana basal; 4) Metástase - as células entram na corrente sanguínea. Adaptado por Silva (2010) de Zaidi, Day e Merlino (2008).

Nesta dissertação apresentamos um modelo de dinâmica espacial de proliferação celular na camada basal da epiderme (monocamada). Consideraremos três tipos celulares: queratinócitos, melanócitos e melanomas. O modelo contempla os eventos de duplicação, morte e migração celular bem como o de mutação. Serão apresentadas simulações com melanomas originando-se de um melanócito (teoria monoclonal) ou de vários (policlonal).

\footnotetext{
${ }^{17}$ Senescência celular replicativa - processo que determina que as células em senescência percam a capacidade proliferativa após um determinado número de divisões celulares (ALBERTS et al., 2015).
} 


\section{UM MODELO ESPACIAL DA DINÂMICA CELULAR ESTOCÁS- TICA COM INTERAÇÃO INIBITÓRIA}

\subsection{O modelo Widom-Rowlinson}

O Modelo Widom-Rowlinson (WR) foi introduzido em 1970 como um modelo para estudar o equilíbrio termodinâmico de um fluido com a existência de uma transição de fase de líquido-vapor (WIDOM; ROWLINSON, 1970). Este modelo permite a análise da dinâmica estocástica de ocupação de um domínio espacial por $q$ tipos de partículas obedecendo um processo de nascimento e morte. A interação entre dois tipos distintos de partículas ocorre por um potencial do tipo "caroço-duro".

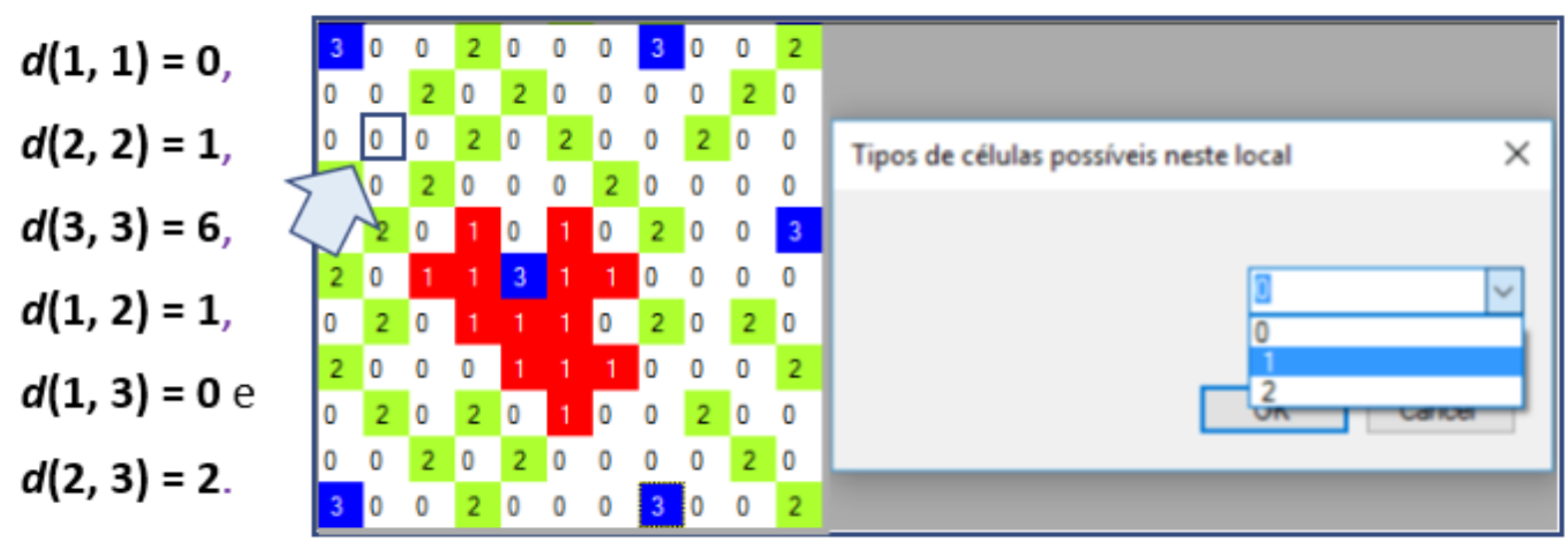

Figura 4 - Regra de restrição à ocupação de um vértice por um determinado tipo de partícula dada a configuração dos vizinhos: $\operatorname{dist}\left(y, y^{\prime}\right)>d(m, n)$, onde a distância dist $\left(y, y^{\prime}\right)$ entre dois vértices $y$ e $y^{\prime}$ é dada pelo menor número de arestas ligando estes vértices e, considerando-se estes dois vértices ocupados, respectivamente, por partículas de tipos $m$ e $n, d(m, n)=d(n, m)$ é o chamado diâmetro de exclusão entre as partículas de tipos $m$ e $n$. Na figura acima o vértice indicado pela seta, só não poderia ser ocupado por uma partícula do tipo 3, porque $d(3,3)=6$ e a distância entre o vértice do canto superior esquerdo, ocupado por uma partícula do tipo 3, e o vértice assinalado é igual a 3, ou seja: dist $\left(y, y^{\prime}\right)<d(3,3)$.

Para simular a dinâmica do modelo WR consideramos uma grade de dimensão $d$ no espaço $\mathbb{Z}^{d}$, que chamaremos $\Lambda$, em que $q$ tipos de partículas interagem ocupando os vértices da grade. Um vértice arbitrário da grade é indicado por $y$ e a distância entre dois vértices $y$ e $y^{\prime}$ é definida como o menor número de arestas ligando estes vértices, chamemos essa distância de $\operatorname{dist}\left(y, y^{\prime}\right)$.

Cada vértice da grade não pode ser ocupado simultaneamente por mais de uma partícula, e seu estado $S_{y}$, assume um valor inteiro indicado por, $\mu$, em que $\mu=0$ indica que o vértice está vazio e $\mu=i$, com $i \in\{1, \cdots, q\}$ indica que o vértice é ocupado por uma partícula de tipo $i$.

Para definir a regra de restrição consideremos um vértice $y$ para o qual queremos analisar a possibilidade de ocupação por uma partícula de tipo $m$ e todos os vértices $y^{\prime}$ de uma 
determinada vizinhança de $y$ ocupados por partículas do tipo $n$. Para que esse vértice $y$ possa ser ocupado por esse tipo de partícula, as distâncias entre o vértice $y$ e todos os vértices $y^{\prime}$ devem obedecer à regra:

$$
\operatorname{dist}\left(y, y^{\prime}\right)>d(m, n)=d(n, m),
$$

onde $d(m, n)$ é o chamado diâmetro de exclusão, distância mínima permitida entre as partículas de tipos $m$ e $n$ (figura 4).

A partícula de tipo $m$ cuja média de $d(m, 1), \cdots, d(m, q)$ é mínima, será chamada de mais tolerante e será menos tolerante a que tiver uma distância de exclusão média maior. A existência de diâmetros de exclusão finitos implica na existência de configurações permitidas na grade e o conjunto de todas as configurações permitidas será indicado por $A_{\Lambda}$.

A dinâmica será estabelecida em termos de uma cadeia de Markov finita a tempo discreto, via um processo de nascimento e morte com a taxa de nascimento da partícula $m$ dada por $p_{m}=p / q$ e uma taxa de morte $p_{0}=1-p$. Assim, seja $|\Lambda|$ o número de vértices da grade, a cada iteração do processo, sorteamos um vértice $y$ em estado $S_{y}$ com probabilidade $1 /|\Lambda|$. O novo estado do vértice será indicado por $S_{y}^{\prime}$ e todos os estados possíveis por $S_{y}^{\prime \prime}$, tal que $S_{y}, S_{y}^{\prime}$ e $S_{y}^{\prime \prime} \in\{0, \ldots, q\}$ e a probabilidade de transição será dada por:

$$
P\left(S_{y}^{\prime}=\mu\right)=\frac{p_{\mu} \times \mathbb{I}\left(S_{y}^{\prime}=\mu \in A_{\Lambda}\right)}{p_{0}+\sum_{v=1}^{q} p_{v} \times \mathbb{I}\left(S_{y}^{\prime \prime}=v \in A_{\Lambda}\right)}, \quad \mu=0, \ldots, q .
$$

em que o símbolo $\mathbb{I}\left(S_{y}^{\prime}=\mu \in A\right)$ representa a função indicadora que garante a restrição dada pela regra da equação (3.1) e é igual a 1 se o novo estado $(\mu)$ for uma configuração permitida dada a ocupação da vizinhança e os diâmetros de exclusão entre $\mu$ e os tipos de partículas presentes na vizinhança e, caso contrário, será zero. No denominador de (3.2), temos que é sempre possível o vértice permanecer ou tornar-se desocupado, isto é, no mínimo, o denominador será igual a $p_{0}=(1-p)$. Essa estrutura é uma versão modificada do algoritmo apresentado em (MAZEL et al., 2014).

\subsubsection{Dinâmica de ocupação de um domínio por três espécies}

A figura abaixo indica uma dinâmica de ocupação de um domínio por três espécies de partículas. O domínio é dado como uma grade bidimensional. Em cada vértice da grade pode ou não haver uma partícula, sendo a ausência de partículas indicada pela cor branca. Nessa simulação há três tipos distintos de partículas, indicadas pelas cores vermelha (tipo 1), verde (tipo 2) e azul (tipo 3). As partículas de tipo 1 apresentam máxima tolerância enquanto que a tolerância mínima é assumida pelas partículas de tipo 3. Na figura 5, no item a), apresentamos a condição inicial, em que, nesse caso, o domínio é circundado pelas partículas de tipo 3. Configurações transientes são apresentadas na figura 5, nos itens b) e c), em que fases dominadas por apenas um tipo de partícula são formadas. No estado estacionário, apresentado pela figura 5 item d), há praticamente duas únicas fases, compostas pelas partículas de tipo 1 e 3 . As partículas de tipo 3 estão presentes devido às bordas do domínio serem fixas no tempo. 

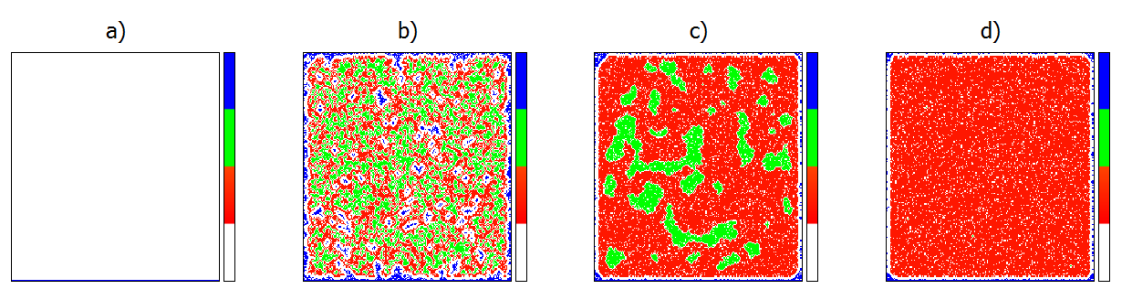

Figura 5 - Dinâmica de ocupação de um domínio bidimensional com três espécies: a) condição inicial, onde o domínio é circundado pelas partículas de tipo 3; b) e c) fases transientes com a formação do domínio por apenas um tipo de partícula; d) estado estacionário com praticamente uma fase, composta predominantemente pelas partículas de tipo 1, com o tipo 3 apenas na região das bordas.

Recentemente, demonstrou-se que no modelo WR homogêneo, onde $p_{\mu}=\frac{p}{q}$, quando $\Lambda \rightarrow \infty$ e em regime estacionário, o domínio espacial será ocupado predominantemente pelas espécies mais tolerantes se $\mathrm{p}$ for suficientemente grande (MAZEL et al., 2014).

\subsubsection{Simulações ilustrando o domínio pela espécie mais tolerante nas condições estabele- cidas pela literatura}

Para ilustrar a comprovação de Mazel et al. (2014) foram realizadas diversas simulações do nosso algoritmo já implementado em um programa utilizando a linguagem C. Aqui serão demonstrados os resultados de três configurações de parâmetros ainda com tratamento de 3 espécies, ou seja, $q=3$.

As dimensões da grade bidimensional, de lado L, são parametrizáveis e foram testadas com $L \in\{100,200\}$. Os parâmetros de tipos de células, foram configurados de forma que o tipo 1 seja representado nos gráficos com a cor vermelha e seja sempre o mais tolerante, em outras palavras, com menor diâmetro de exclusão, a partícula de tipo 2 será apresentada com a cor verde e um $d$ intermediário e a partícula de tipo 3 com a cor azul e representando o tipo com maior diâmetro de exclusão, ou seja, menor tolerância. Assim, cada um dos $|\Lambda|$ vértices será rotulado com $\mu \in\{0,1,2,3\}$. O tipo zero $(\mu=0)$ significará que o vértice está desocupado. Os diâmetros de exclusão utilizados foram os seguintes: $d(1,2)=0, d(1,3)=2, \mathrm{~d}(2,3)=4 \mathrm{e}$ $d(1,1)=d(2,2)=d(3,3)=0$.

Para a probabilidade global de nascimento, ou seja, o parâmetro $\mathrm{p}$, utilizamos $p=0,96$. A parametrização permite tanto que trabalhemos com assimetria nas taxas de crescimento como também com taxas iguais, desde que $p_{1}+p_{2}+\cdots+p_{q}=p$. As condições de contorno, ou seja, a situação inicial dos limites da grade, foram definidas utilizando-se o sistema de coordenadas $(x, y)$ em termos das linhas em $x_{1}=0, x_{2}=L, y_{1}=0$ e $y_{2}=L$. Utilizamos uma convenção para rotular as condições de contorno definindo-se como CCnm, onde $n$, representa as linhas limites em $x_{1}$ e $x_{2}$ e $m$ as linhas $y_{1}$ e $y_{2}$, assim, um rótulo $C C 12$, indicará que inicialmente foram posicionadas células do tipo 1 nos limites $x_{1}$ e $x_{2}$ e células do tipo 2 nos limites $y_{1}$ e $y_{2}$. No 
caso de todas as linhas iniciarem da mesma forma, será apontado apenas uma vez o tipo que as preencherá, por exemplo, CC0 significa que os limites não foram preenchidos com nenhuma espécie (tipo $=0$ ) e CC3 que todos os limites (bordas) foram preenchidos com o tipo 3.

A partir dos parâmetros indicados anteriormente foram realizadas simulações com $1 \times$ $10^{9}$ iterações, mais ou menos, até atingir-se um estado estacionário, chegando-se nos resultados apresentados a seguir.

\subsubsection{Dinâmica de simulação com $C C 3, L=200, \mathrm{p}_{1}=\mathrm{p}_{2}=0,40$ e $\mathrm{p}_{3}=0,16$}

O modelo apresentou resultados regulares com crescimento constante da espécie 1 até entrar em regime estacionário com ocupação aproximada de $83 \%$ dos nós por volta de $2,62 \times 10^{8}$ iterações, após a extinção da espécie 2 (praticamente). A espécie do tipo 3 teve seu pico por volta de $1,56 \times 10^{5}$ iterações com aproximadamente $6,4 \%$ de ocupação dos nós, oscilou na maioria do tempo entre $3 \%$, porém, após a queda da espécie 2 para apenas $0,0125 \%$ e oscilando daí para baixo (sempre menos que 5 nós ocupados), a espécie 3 estabilizou em cerca de 2,8\% dos nós. Conforme observamos nas figuras 6 e 7.
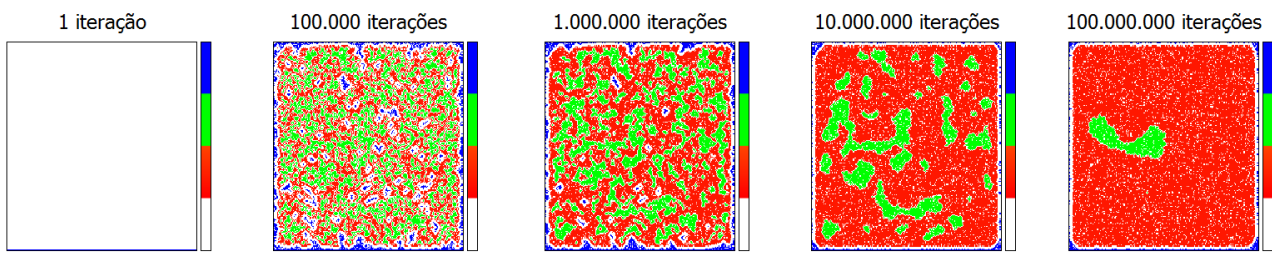

268.750.000 iterações

Figura 6 - Situações em períodos diversos da simulação com CC3, L $=200, p_{1}=p_{2}=0,40$ e $p_{3}=0,16$

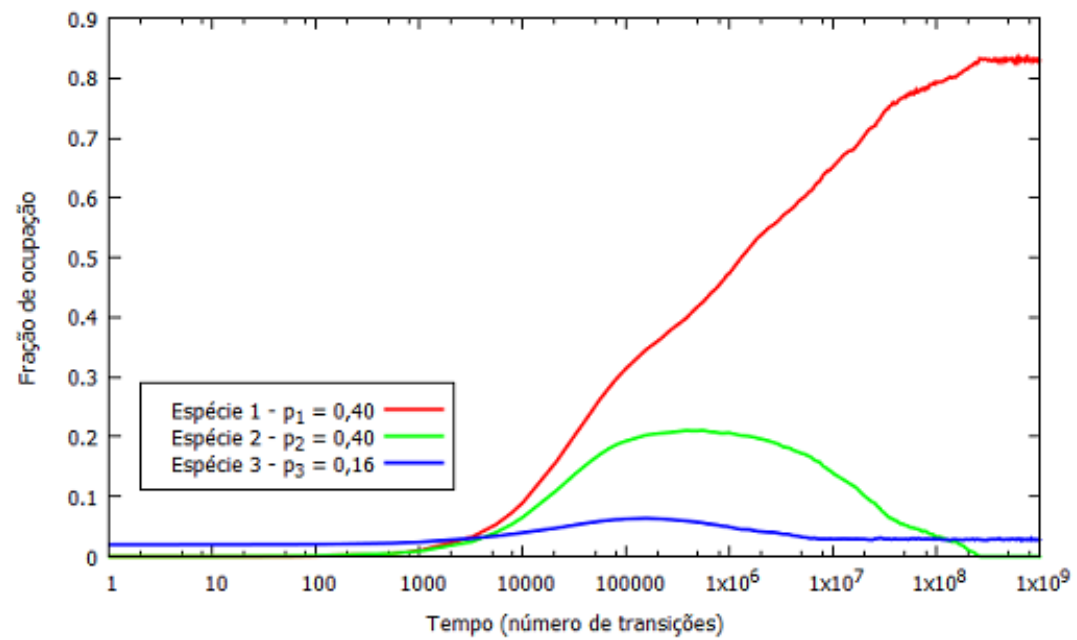

Figura 7 - Dinâmica da ocupação da simulação com CC3, L $=200, p_{1}=p_{2}=0,40$ e $p_{3}=$ 0,16 


\subsubsection{Dinâmica de simulação com $C C 3, L=200, \mathrm{p}_{1}=\mathrm{p}_{2}=\mathrm{p}_{3}=0,32$}

O modelo apresentou resultados com inversões, no início com crescimento constante da espécie 1 , porém após a extinção da espécie 2 , houve um desequilíbrio do crescimento da espécie 3, que passou a crescer a taxas elevadas e a espécie 1 entrou em declínio constante. Dessa forma observa-se claramente que a espécie 3 será dominante em regime estacionário. A espécie 2 teve seu pico próximo a 10\% de ocupação, porém sua tolerância intermediária não trouxe vantagem e passou a perder espaço até que, por volta de $4,80 \times 10^{7}$ iterações, caiu abaixo de $0,028 \%$ e não se recuperou mais. Nessa ocasião a ocupação da célula tipo 3 oscilava em torno de $14 \%$, mas a partir daí, cresceu rapidamente e quando encerramos a simulação, estava com $67 \%$, ainda sem alcançar o pico da célula tipo 1 que foi de cerca de $71 \%$ por volta da iteração $5,22 \times 10^{7}$. Porém, pode-se afirmar que ela terminaria ocupando todo o espaço de $\Lambda$. Isto se deve à pressão da borda fixa na espécie 3 (figuras 8 e 9).
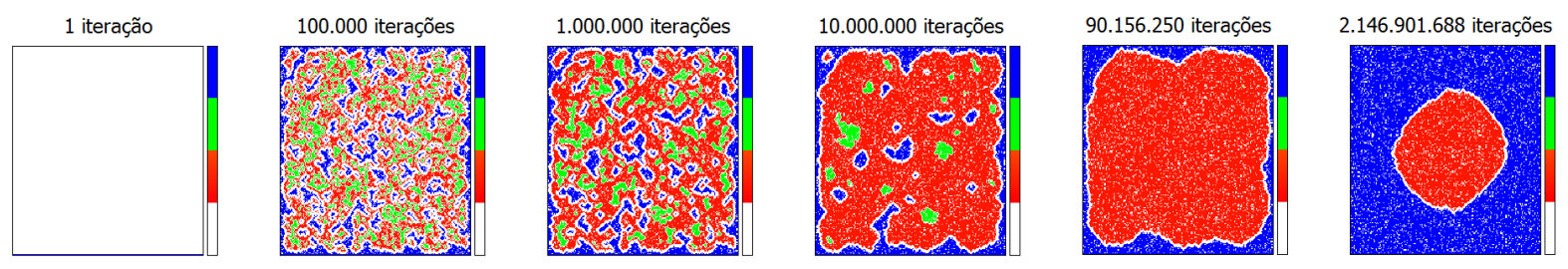

Figura 8 - Situações em períodos diversos da simulação CC3, $\mathrm{L}=200, p_{1}=p_{2}=p_{3}=0,32$

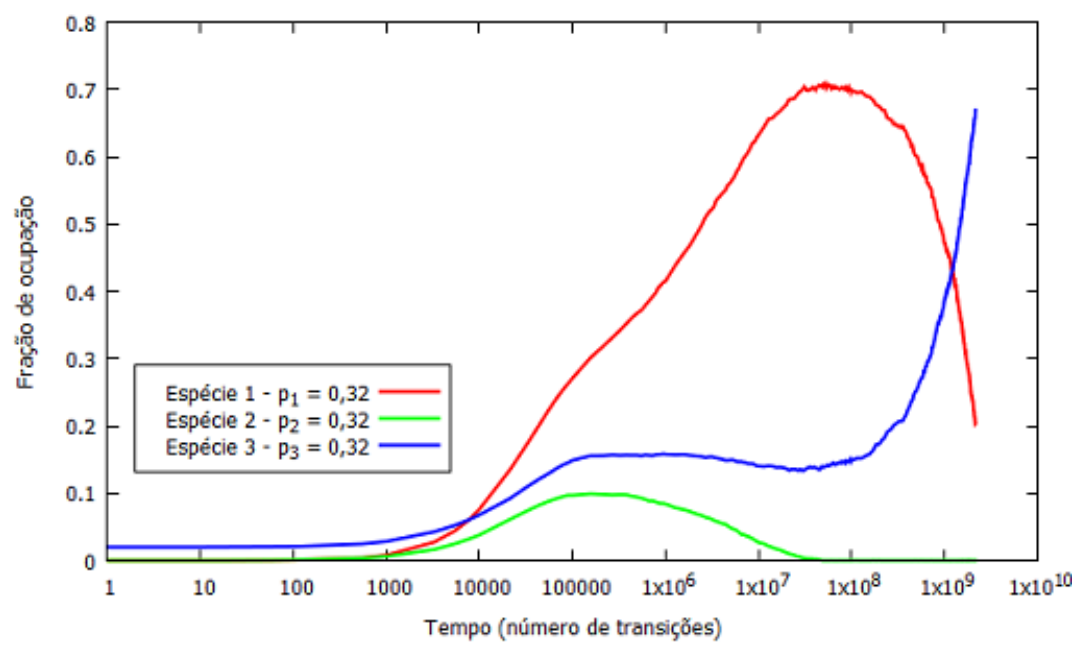

Figura 9 - Dinâmica da ocupação da simulação CC3, $\mathrm{L}=200, p_{1}=p_{2}=p_{3}=0,32$

\subsubsection{Dinâmica de simulação com CCO, $L=200, \mathrm{p}_{1}=\mathrm{p}_{2}=\mathrm{p}_{3}=0,32$}

O modelo apresentou resultados regulares com crescimento constante da espécie 1 até entrar em regime estacionário com ocupação aproximada de $87 \%$ dos nós por volta de $1,77 \times 10^{8}$ iterações, quando as células do tipo 2 entraram em estado de extinção. As células do tipo 2 tiveram seu pico de ocupação de $12,5 \%$ por volta de $2,13 \times 10^{5}$ iterações, estabilizando-se nesse 
patamar até $3,81 \times 10^{5}$, quando começou a declinar. As células do tipo 3 , apresentaram pico de $9,1 \%$ em mais ou menos $2,69 \times 10^{5}$ iterações e, em função de seu grande $d$, que as impedia de se aproximar de espaços já ocupados, extinguiram-se totalmente em aproximadamente $1,07 \times 10^{8}$ iterações (figuras 10 e 11).
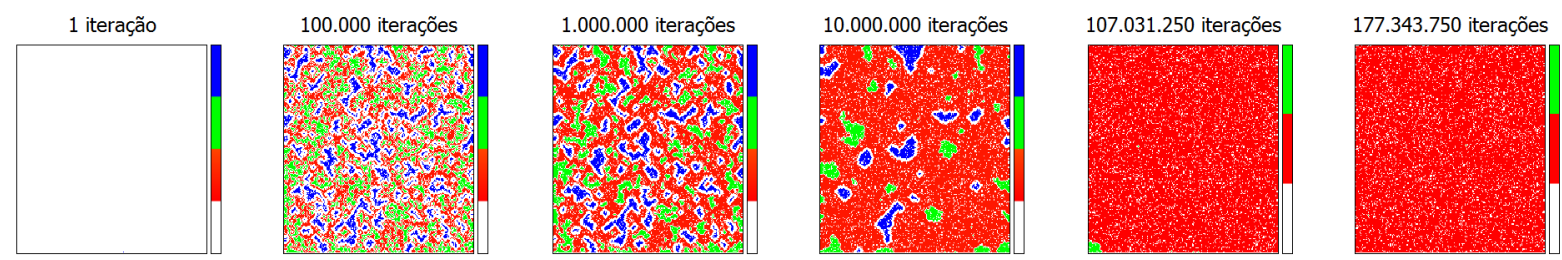

Figura 10 - Situações em períodos diversos da simulação $\mathrm{CC} 0, \mathrm{~L}=200, p_{1}=p_{2}=p_{3}=$ 0,32

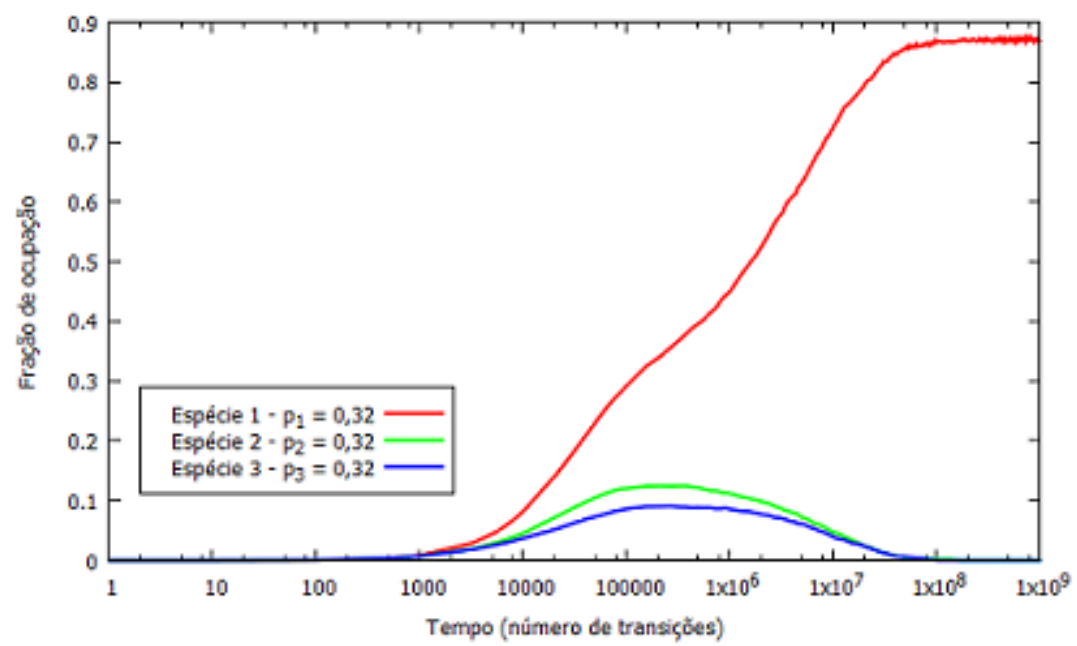

Figura 11 - Dinâmica da ocupação da simulação CC0, $\mathrm{L}=200, p_{1}=p_{2}=p_{3}=0,32$

\subsubsection{Dinâmica de simulação com $C C 0, L=100, \mathrm{p}_{1}=\mathrm{p}_{2}=\mathrm{p}_{3}=0,32$}

Podemos observar nas figuras 12 e 13, que, em uma grade de dimensões menores $(\mathrm{L}=$ 100) e ainda sem a pressão da borda fixa com elementos do tipo 3, este último tipo não consegue uma ocupação além de pouco menos de $10 \%$.
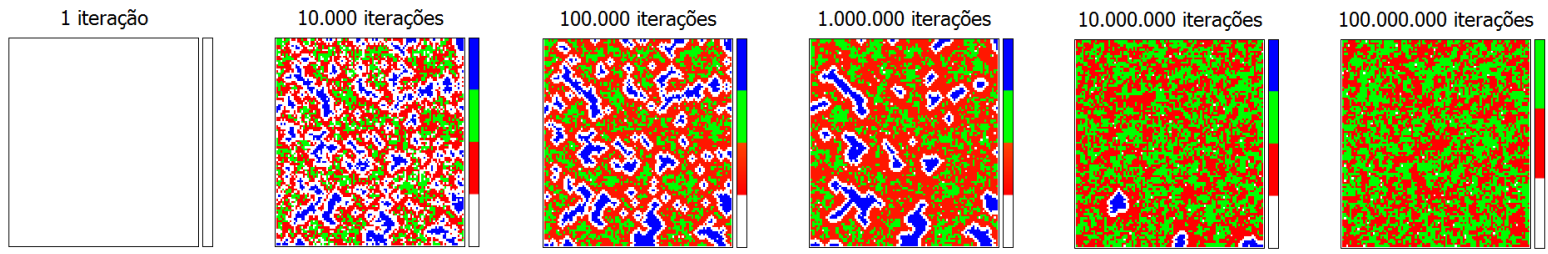

Figura 12 - Situações em períodos diversos da simulação CC0, $\mathrm{L}=100, p_{1}=p_{2}=p_{3}=$ 0,32 
A espécie 3, que não consegue manter um equilíbrio de ocupação devido ao crescimento do número dos elementos do tipo 1, entra em um processo de extinção, quando verificamos o crescimento acentuado da ocupação pelos elementos do tipo 2 e, assim que esse processo se completa por volta de $1,9 \times 10^{7}$ iterações, o tipo 2 entra em um equilíbrio de coexistência com os elementos do tipo 1, com os dois tipos oscilando em ocupações entre $47 \%$ e $49 \%$.

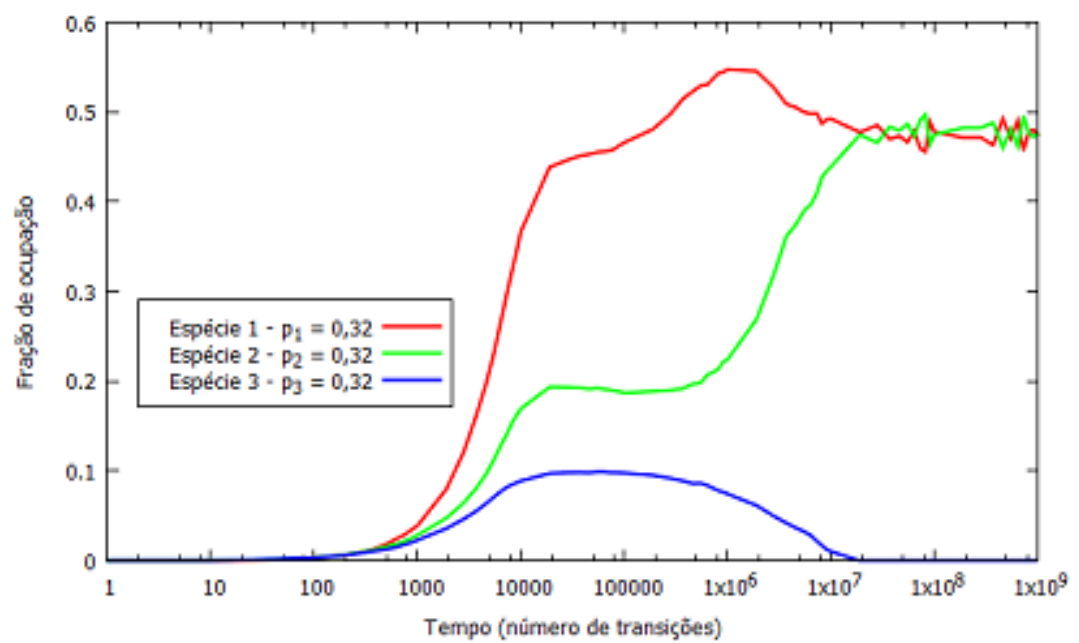

Figura 13 - Dinâmica da ocupação da simulação CC0, L = 100, $p_{1}=p_{2}=p_{3}=0,32$

\subsubsection{Dinâmica de simulação com CC3, $L=100, \mathrm{p}_{1}=\mathrm{p}_{2}=\mathrm{p}_{3}=0,32$}

Quando incluímos uma condição de contorno com preenchimento de elementos do tipo 3, como observado nas figuras 14 e 15, verificamos inversões nos níveis de ocupação entre os tipos 1 e 3 (pouco depois de $2,8 \times 10^{3}$ iterações) e também entre os tipos 2 e 3 (por volta de $1,5 \times 10^{6}$ iterações). No entanto, o que podemos observar após $1,0 \times 5,5^{9}$ iterações é um certo equilíbrio com oscilações na ordem de no máximo 3,2 pontos percentuais (para o caso do tipo 3 ) e no mínimo 1,6 pontos (no caso do tipo 1) na ocupação dos três tipos presentes na grade. Com a fração de ocupação em torno de $38,75 \%$ para o tipo 1 e $31,9 \%$ e $23,24 \%$ para os tipos 2 e 3 , respectivamente.
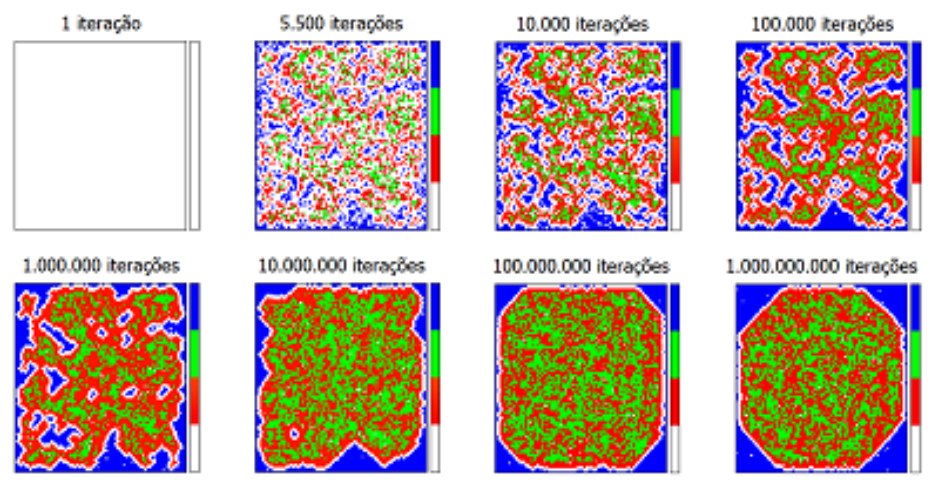

Figura 14 - Situações em períodos diversos da simulação CC3, $\mathrm{L}=100, p_{1}=p_{2}=p_{3}=$ 0,32 


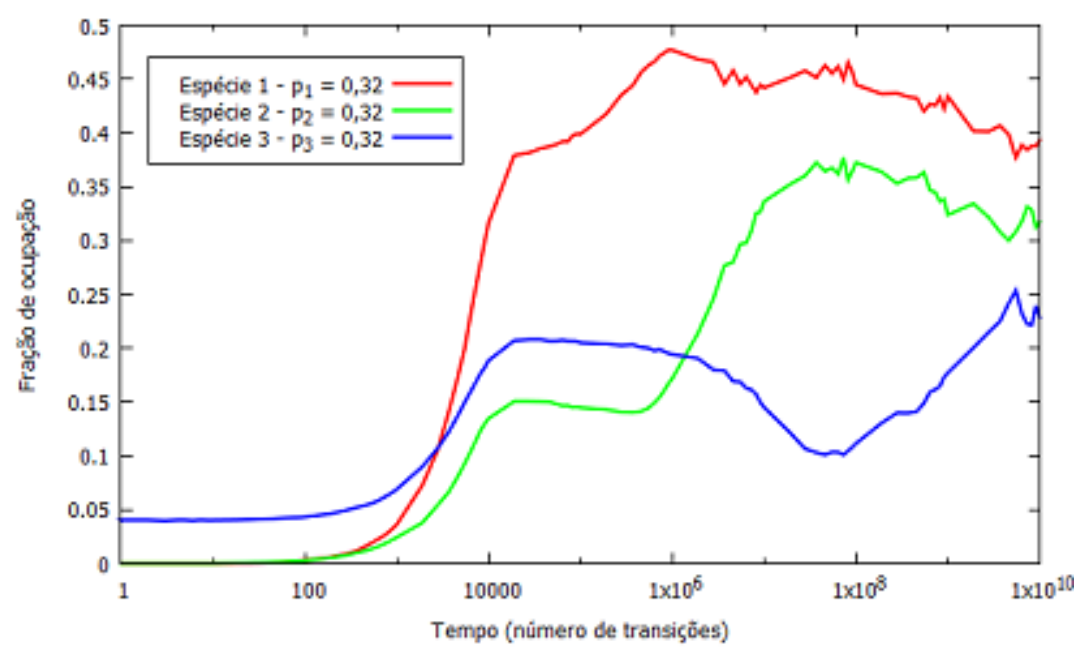

Figura 15 - Dinâmica da ocupação da simulação CC3, $\mathrm{L}=100, p_{1}=p_{2}=p_{3}=0,32$

\subsection{Um modelo espacial de dinâmica celular estocástica}

No intuito de termos um modelo adequado para a biologia celular do câncer, fomos introduzindo novas características até um ponto em que chegamos a algo inédito quando comparado com as ideias originais de Widom e Rowlinson (1970). Nesta seção apresentaremos essas inovações.

Nos experimentos de biologia celular as grandezas mensuráveis são taxas de nascimento e morte. Portanto, com vistas a estabelecer uma correspondência mais precisa com os experimentos, refraseamos as probabilidades $p_{\mu}, \mu \in\{0,1, \ldots, q\}$ em termos de taxas. Da mesma maneira, nosso modelo deve contemplar características importantes da dinâmica de ocupação e proliferação celular: a motilidade e a transformação celular. Assim, para que possamos prosseguir, devemos redefinir o modelo em termos de taxas no lugar das probabilidades e também incluir a utilização de taxas de motilidade e, para um tipo celular específico, de taxa de transformação celular, ou seja, da possibilidade que esse tipo celular, no momento da duplicação, gere outro. Importante aprimoramento é também a da particularização das taxas de mortalidade para cada tipo celular, o que não era possível no modelo WR puro.

\subsubsection{Controle de transição}

Para representarmos de maneira adequada a duplicação celular e a transformação celular (mutação), introduziremos o conceito de controle de transição no modelo WR modificado, dessa forma poderemos controlar se em um nó sem vizinhos poderá nascer uma célula ou não e também em que situação um tipo celular poderá dar origem a um outro.

Isto foi feito através da inclusão opcional no grupo de parâmetros, de informações sobre as transições permitidas de um tipo celular para outro. Assim, essas restrições passam a ser analisadas em conjunto com aquelas do diâmetro de exclusão para a tomada de decisão de cada nova transição. 


\subsubsection{Probabilidades no modelo}

Definamos: $\alpha_{\mu}$, como as taxas de crescimento (duplicação) das células do tipo $\mu=$ $1,2, \cdots, q$, ou seja, $\alpha_{1}, \alpha_{2}, \cdots, \alpha_{q} ; \delta_{\mu}$, como as taxas de motilidade desses mesmos tipos celulares: $\delta_{1}, \delta_{2}, \cdots, \delta_{q} ; \rho$, como a somatória das taxas de mortalidade dos tipos celulares, ou seja, $\rho=\rho_{1}+\rho_{2}+\cdots+\rho_{q}$ e $\alpha_{t}$ a taxa de duplicação com transformação celular que poderá acontecer apenas com um determinado tipo celular. A cadeia de Markov finita a tempo discreto é definida como segue.

Dado que $|\Lambda|$ é o número de nós da grade $\Lambda$, a cada iteração do processo, um vértice $y$ da grade em estado $S_{y}$ é sorteado a probabilidade $1 /|\Lambda|$. O novo estado do vértice será indicado por $S_{y}^{\prime}$, tal que $S_{y}, S_{y}^{\prime} \in\{0, \ldots, q\}$ e o conjunto de todas as configurações permitidas na grade $\Lambda$ alterando-se o vértice $y$ e seus vértices vizinhos $V_{y}$ será indicado por $A_{\Lambda}$. $S_{y}^{\prime \prime}$ representará os estados possíveis de acordo com os diâmetros de exclusão e $T_{V}$ a taxa de cada um destes $v$ estados possíveis, seja por migração ou duplicação, isto é, $T_{v} \in\left\{\alpha_{1}, \ldots, \alpha_{q}, \delta_{1}, \ldots, \delta_{q}\right\}$.

Assim, a probabilidade de um vértice $y$ sorteado permanecer no estado vazio é:

$$
P\left(S_{y}^{\prime}=0 \operatorname{com} S_{y}=0\right)=\frac{\rho}{\rho+\sum_{v=1}^{q} T_{v} \times \mathbb{I}\left(S_{y}^{\prime \prime}=v \in A_{\Lambda}\right)},
$$

em que $\mathbb{I}\left(S_{y}^{\prime \prime}=v \in A_{\Lambda}\right)$ é a função indicadora queé igual a 1 para todo estado $S_{y}^{\prime \prime}=v$ que pertencer a uma configuração permitida em $\Lambda$ e igual a zero caso contrário.

A probabilidade do vértice $y$ ocupado por uma célula do tipo $\mu$, que pode sofrer transformação celular à taxa $\alpha_{t}$, permanecer nesse estado é:

$$
P\left(S_{y}^{\prime}=\mu \operatorname{com} S_{y}=\mu\right)=\frac{\alpha_{\mu} \times \sum_{\left\{V_{y \alpha}\right\}} \mathbb{I}\left(S_{V_{y \alpha}}=\mu \in A_{\Lambda}\right)+\alpha_{t} \times \sum_{\left\{V_{y t}\right\}} \mathbb{I}\left(S_{V_{y t}}=\mu \in A_{\Lambda}\right)}{\rho_{\mu}+N}
$$

com $N$ sendo igual a soma de todas as possibilidades condicionadas às regras do diâmetro de exclusão para o tipo $\mu$ nos vértices vizinhos:

$$
N=\delta_{\mu} \times \sum_{\left\{V_{y \delta}\right\}} \mathbb{I}\left(S_{V_{y \delta}}=\mu \in A_{\Lambda}\right)+\alpha_{\mu} \times \sum_{\left\{V_{y \alpha}\right\}} \mathbb{I}\left(S_{V_{y \alpha}}=\mu \in A_{\Lambda}\right)+\alpha_{t} \times \sum_{\left\{V_{y t}\right\}} \mathbb{I}\left(S_{V_{y t}}=\mu \in A_{\Lambda}\right)
$$

em que $\mu=1, \ldots, q,\left\{V_{y \delta}\right\},\left\{V_{y \alpha}\right\}$ e $\left\{V_{y t}\right\}$ representam, respectivamente, os conjuntos dos vizinhos para migração, duplicação e transformação celular e $S_{V_{y \delta}}, S_{V_{y \alpha}}$ e $S_{V_{y t}}$, os estados desses vizinhos.

A probabilidade do vértice $y$ ser desocupado por morte ou migração de uma célula tipo $\mu$ é dada por:

$$
P\left(S_{y}^{\prime}=0 \operatorname{com} S_{y}=\mu\right)=\frac{\rho_{\mu}+\delta_{\mu} \times \sum_{\left\{V_{y \delta}\right\}} \mathbb{I}\left(S_{V_{y \delta}}=\mu \in A_{\Lambda}\right)}{\rho_{\mu}+N}
$$

\subsubsection{A interface gráfica do simulador}

Foi desenvolvida uma aplicação que serve ao mesmo tempo como configurador das simulações, gerando uma configuração inicial da distribuição celular e arquivo de configuração, 
como também, um organizador dos arquivos dos resultados obtidos nas simulações. Isto permite que se possa armazenar disposições da grade e simular diversas condições a partir daquele ponto. Uma aplicação é de criarmos a condição inicial a partir de várias execuções do simulador. Um exemplo prático é o que foi utilizado nas simulações cujos resultados encontram-se abaixo, nas seções do capítulo 4. 


\section{RESULTADOS}

Realizamos duas classes de simulações, na primeira baseamo-nos na teoria policlonal, ou seja, todos os melanócitos podem originar melanomas. Na outra, apenas um melanócito dá início ao melanoma (teoria monoclonal). -

\subsection{Configuração inicial}

A grade tem dois espaços distintos, os vértices nas suas bordas (condições de contorno), cuja ocupação não muda durante a dinâmica, e os vértices no seu interior (figura 16).

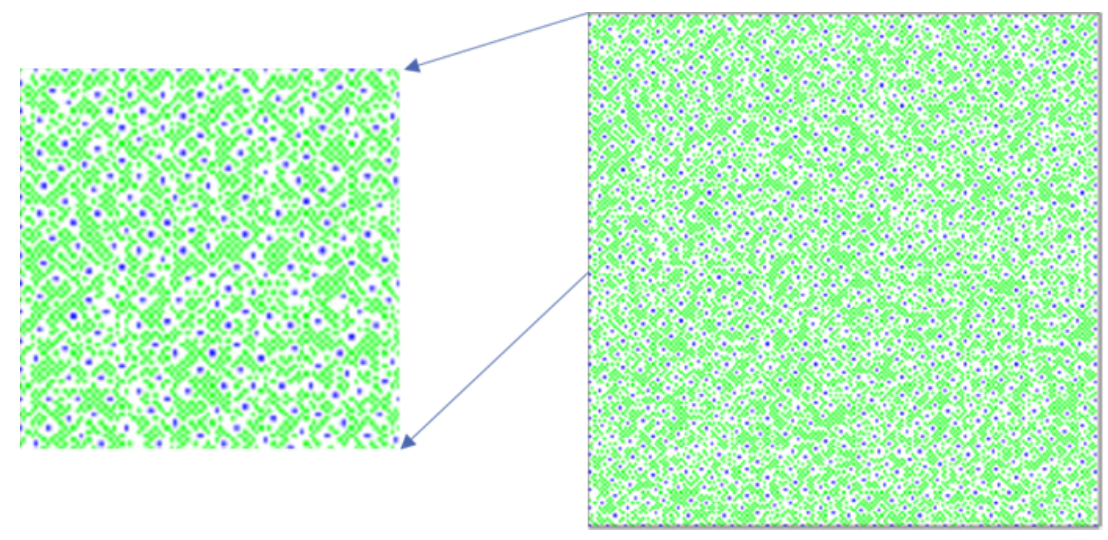

Figura 16 - Condições iniciais geradas em três passos de execução do modelo

Para gerarmos a proporção de 1:10 entre melanócitos e queratinócitos, encontrada na literatura, a configuração inicial foi definida em três passos. Primeiro, utilizando uma ferramenta da interface gráfica do simulador (seção 3.2.3) para gerar o contorno com ocupação de melanócitos e queratinócitos e, depois, duas execuções do modelo. A execução inicial para a ocupação unicamente por melanócitos, utilizou como entrada a configuração só com as bordas preenchidas geradas na primeira fase. Em seguida, outra execução para a ocupação também pelos queratinócitos, utilizando como entrada a nova configuração, agora com a borda fixa e o interior preenchido com os melanócitos do segundo passo. Tudo isso, sempre respeitando os diâmetros de exclusão definidos nos parâmetros dos dois programas (a interface gráfica e o simulador). A última tarefa foi escolher uma das configurações de saída onde tivéssemos a proporção pretendida para ser utilizada como configuração inicial nas simulações. O resultado alcançado foi a proporção de 0,99981:10.

\subsection{Resultados com melanomas, queratinócitos e com todos melanócitos podendo gerar melanomas (policlonal)}

Nesta classe de simulações, todos os melanócitos podem gerar células de melanoma. Em outras palavras, qualquer elemento do tipo 3, que representa o melanócito, pode sofrer o evento de duplicação, mas gerando o tipo 1, o melanoma. 


\subsubsection{Simulações tipo 1: policlonal com variações de $\alpha_{1}$ e com $\alpha_{2}$ e $\alpha_{3}$ fixos e iguais a} 0,2225

Para esta série de simulações, foram definidas taxas com o intuito de observação do potencial exercido pela maior tolerância dos melanomas: $\alpha_{2}=\alpha_{\mathbf{3}}=\mathbf{0}, \mathbf{2 2 2 5}, \rho_{\mathbf{1}}=\rho_{\mathbf{2}}=\mathbf{0 , 0 2}$, $\rho_{3}=\mathbf{0}$ e $\delta_{1}=\delta_{2}=\delta_{3}=\frac{\mathbf{0 , 4 6}}{\mathbf{3}}$.
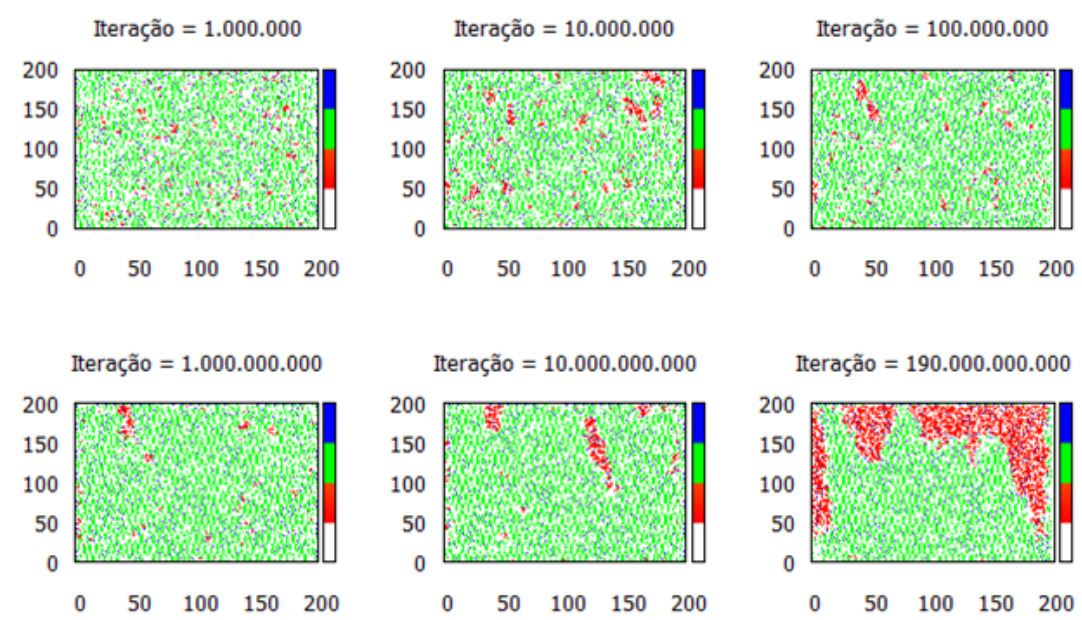

Figura 17 - Mapas de ocupação de simulação do tipo 1 (policlonal) com $\alpha_{1}=0,03$ e $\alpha_{2}=$ $\alpha_{3}=0,2225$

\subsubsection{Simulação tipo 1: $\alpha_{1}=0,0300$}

Verificamos o início da formação de agrupamentos significativos e mais persistentes de melanomas depois de 10 bilhões de iterações (figura 17) ocupando cada vez mais a grade até 100 bilhões de iterações. Na figura 18, observamos uma tendência de acentuado crescimento dos melanomas a partir de 10 bilhões de iterações, no final, após 190 bilhões de iterações, ocupava cerca de $15,6 \%$ dos vértices da grade.

\subsubsection{Simulação tipo 1: $\alpha_{1}=0,0350$}

Nesta simulação observamos que as tendências manifestadas na simulação de 4.2.1.1 foram confirmadas. Verificamos a formação de agrupamentos significativos já a partir de 100 milhões de iterações, alguns deles persistindo, como se pode notar nos mapas de ocupação após 1 bilhão e 10 bilhões de iterações (figura 19).

Com um aumento de cerca de $17 \%$ na taxa de duplicação de melanomas, vimos o crescimento aumentar de forma muito acentuada a partir de 2,8 bilhões de iterações, ou seja, muito antes do observado na outra simulação. A ocupação dos melanomas tornou-se maior que a dos queratinócitos por volta de 46 bilhões de iterações e continuou crescendo, ultrapassando $31 \%$ de ocupação (figura 20). 


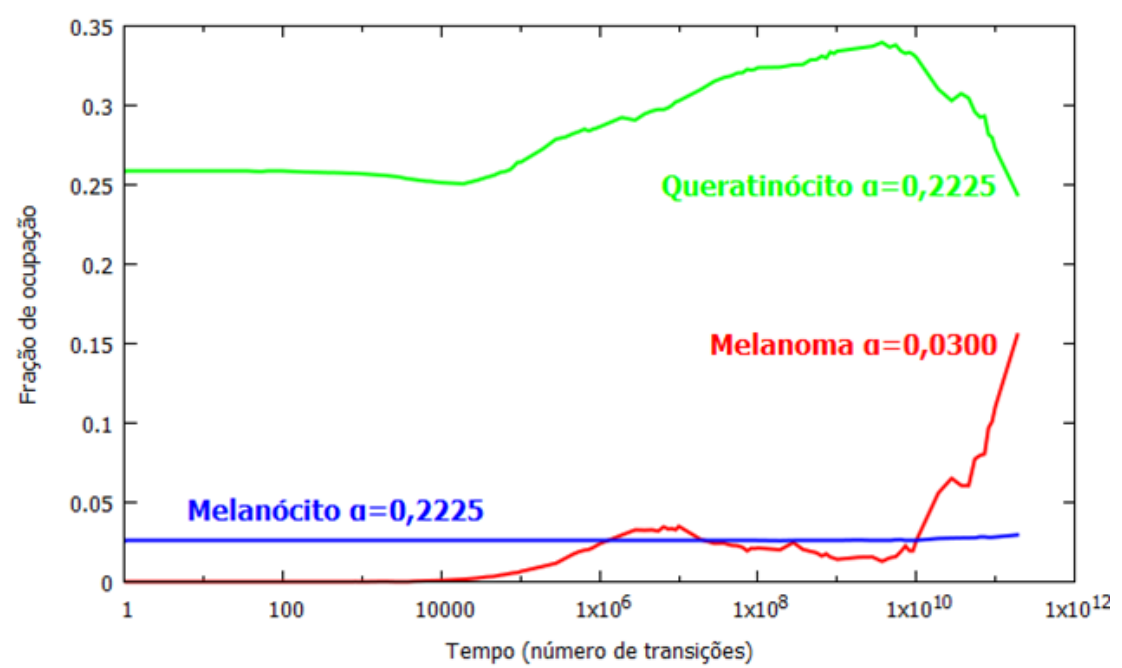

Figura 18 - Dinâmica de ocupação de simulação do tipo 1 (policlonal) com $\alpha_{1}=0,0300$ e $\alpha_{2}=\alpha_{3}=0,2225$
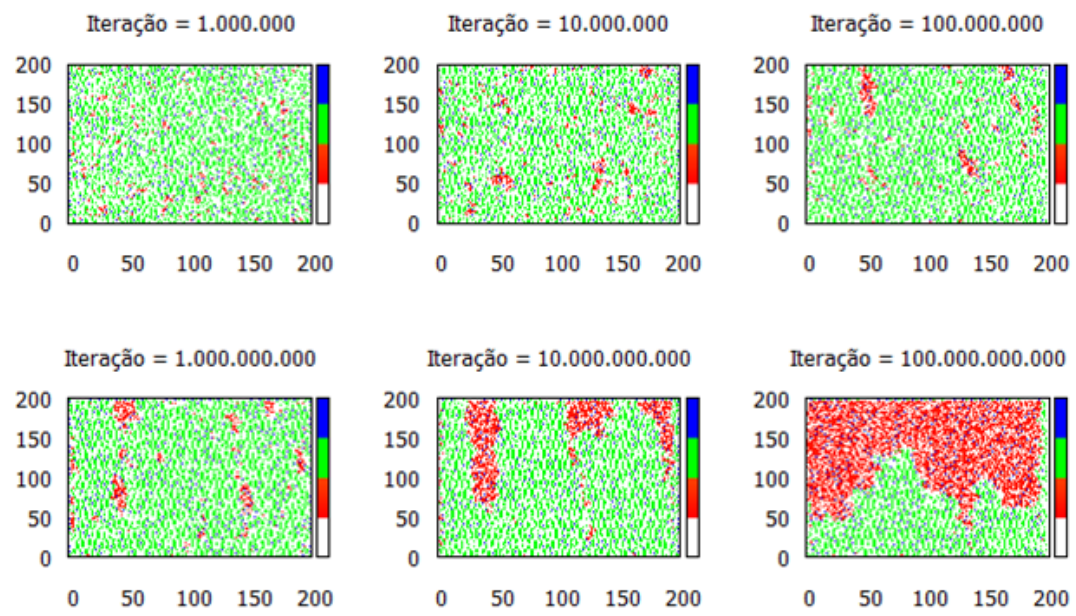

Figura 19 - Mapas de ocupação de simulação do tipo 1 (policlonal) com $\alpha_{1}=0,0350$ e $\alpha_{2}=\alpha_{3}=0,2225$

\subsubsection{Simulações tipo 2: policlonal com variações de $\alpha_{1}=\alpha_{3}$ com $\alpha_{2}$ fixo e igual a 0,2225}

Nesta série de simulações procuramos encontrar um ponto de equilíbrio, onde pudesse haver um sinal de coexistência dos queratinócitos e melanomas. Para isso, passamos a variar também a taxa de duplicação dos melanócitos, acompanhando a variação dos melanomas. A taxa dos queratinócitos permaneceu fixa, $\alpha_{2}=0,2225$. As demais taxas permaneceram as mesmas, ou seja, $\rho_{1}=\rho_{2}=\mathbf{0}, \mathbf{0 2}, \rho_{3}=\mathbf{0}$ e $\delta_{1}=\delta_{2}=\delta_{3}=\frac{\mathbf{0 , 4 6}}{\mathbf{3}}$.

\subsubsection{Simulação tipo 2: $\alpha_{1}=\alpha_{3}=0,0200$}

Nesta simulação pudemos observar que a situação não mudou muito em relação àquela da simulação com $\alpha_{1}=0,03$ da seção 4.2.1.1, comparando a figura 21 com a 17 daquela seção, podemos notar formações de agrupamentos bastante parecidas após 10 bilhões de iterações. 


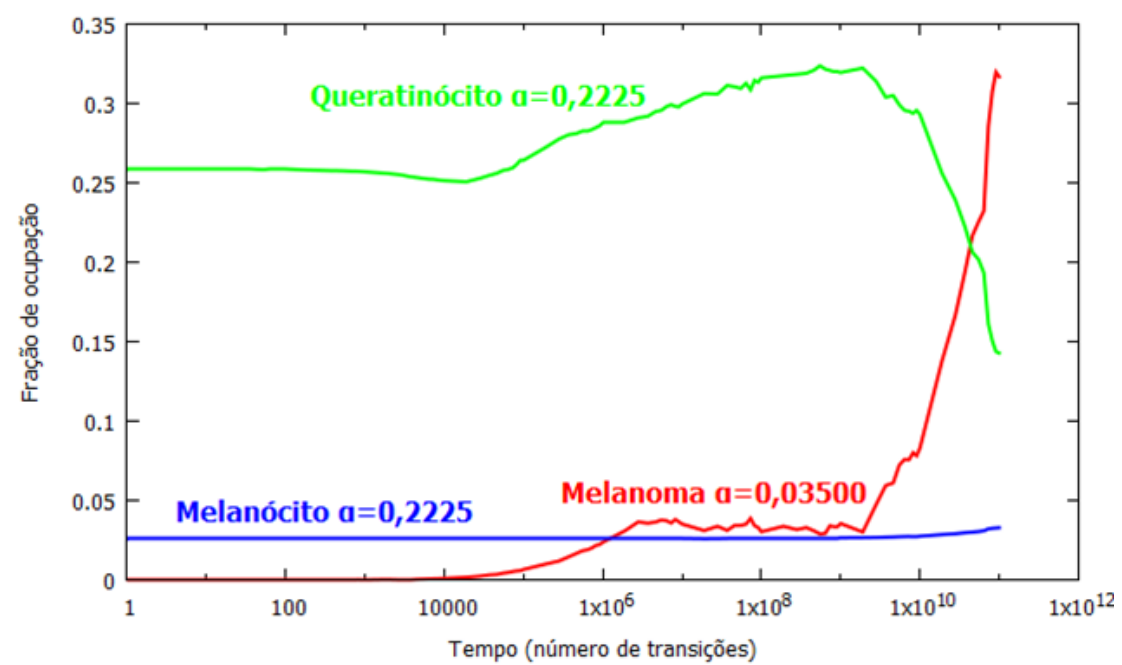

Figura 20 - Dinâmica de ocupação de simulação do tipo 1 (policlonal) com $\alpha_{1}=0,0350$ e $\alpha_{2}=\alpha_{3}=0,2225$
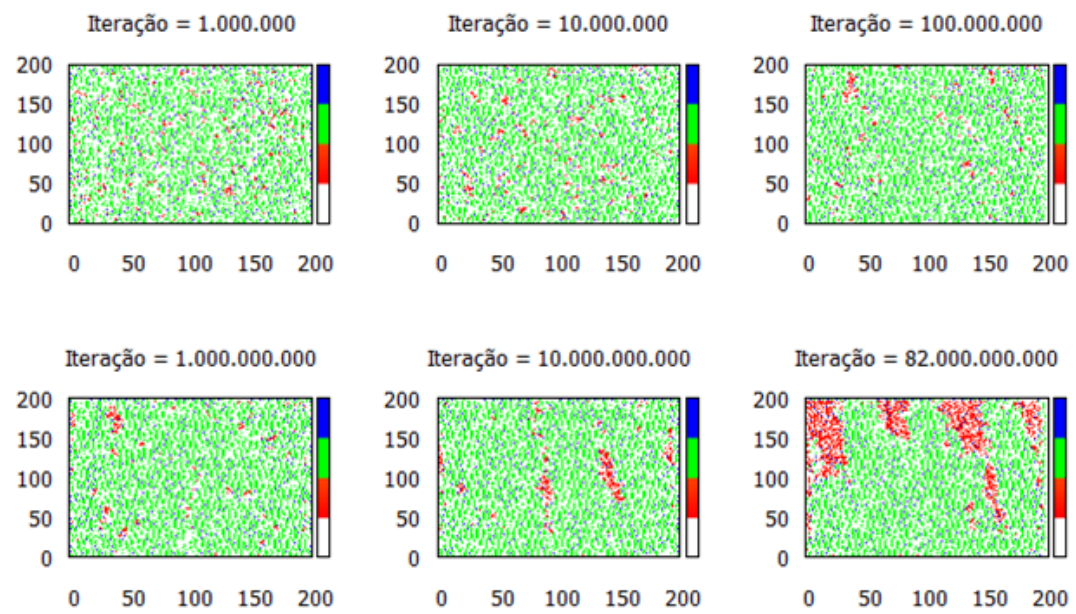

Figura 21 - Mapas de ocupação de simulação do tipo 2 (policlonal) com $\alpha_{1}=\alpha_{3}=0,0200$ e $\alpha_{2}=0,2225$

Essa semelhança mostra que as mudanças efetuadas nos parâmetros, tanto a diminuição de um terço na taxa de duplicação do melanoma (de 0,03 para 0,02 ), como também a redução da taxa de duplicação dos melanócitos para cerca de $9 \%$ do que era na outra simulação (de 0,2225 para 0,02), não mudaram as tendências de crescimento do melanoma. Da mesma forma, na figura 22, notamos que após 82 bilhões de iterações a ocupação dos melanomas não havia ultrapassado os $10 \%$ dos vértices, o que na outra simulação (figura 18) também só ocorreu depois, muito próximo de $1 \times 10^{11}$ iterações.

\subsubsection{Simulações tipo 3: variações de $\alpha_{2} \operatorname{com} \alpha_{1}=\alpha_{3}$ fixos e iguais a 0,0400}

Nessa série, ainda buscávamos alguma combinação de parâmetros onde houvesse uma persistência de ambos os tipos 1 e 2 que representam, respectivamente, os melanomas e os queratinócitos. As demais taxas permaneceram as mesmas, ou seja, $\rho_{\mathbf{1}}=\rho_{\mathbf{2}}=\mathbf{0}, \mathbf{0 2}, \rho_{\mathbf{3}}=\mathbf{0}$ e 


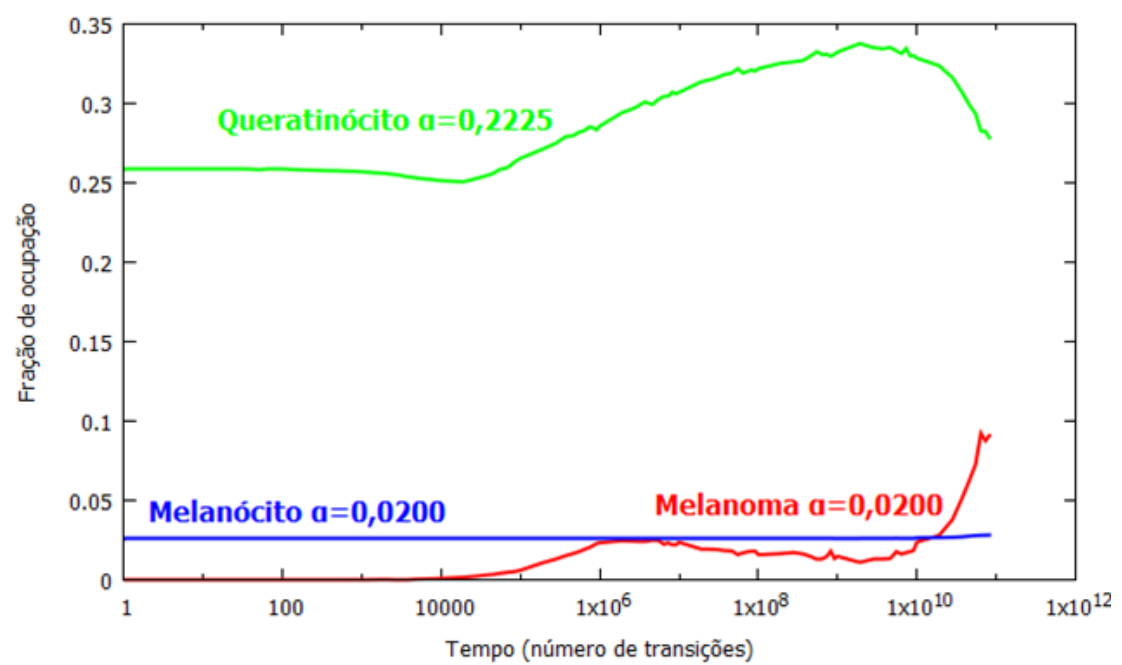

Figura 22 - Dinâmica de ocupação de simulação do tipo 2 (policlonal) com $\alpha_{1}=\alpha_{3}=$ 0,0200 e $\alpha_{2}=0,2225$

$\delta_{1}=\delta_{2}=\delta_{3}=\frac{0,46}{3}$
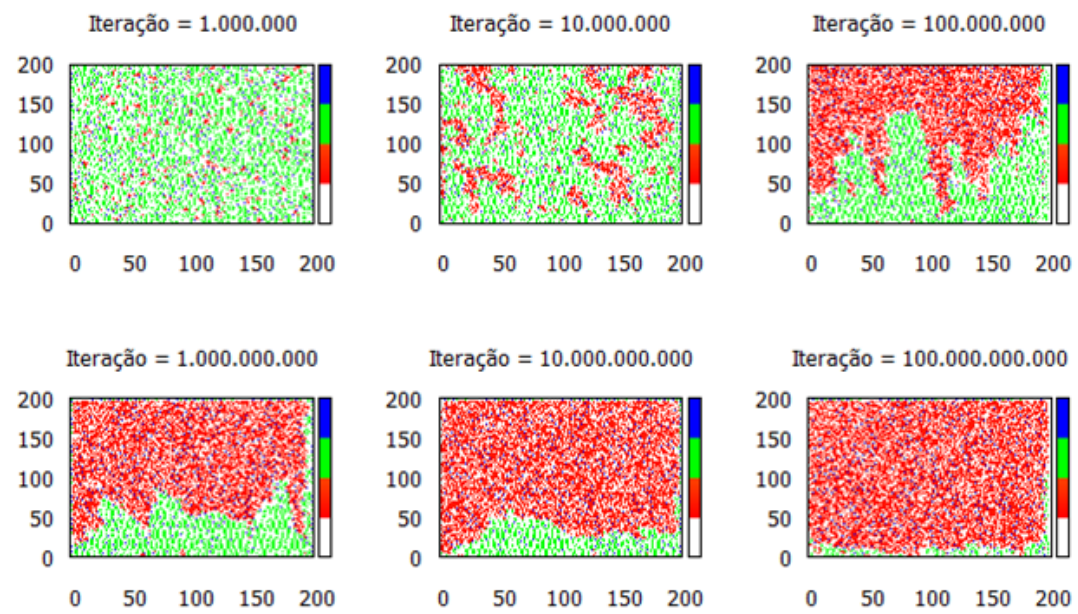

Figura 23 - Mapas de ocupação de simulação do tipo 3 (policlonal) com $\alpha_{2}=0,1000$, $\alpha_{1}=\alpha_{3}=0,04$

\subsubsection{Simulação tipo 3: $\alpha_{2}=0,1000$}

Nesta simulação, em que a taxa de duplicação dos queratinócitos tem menos da metade do valor do que vínhamos simulando, era de se esperar que os melanomas ocupassem os vértices de forma mais rápida, e, de fato, foi o que aconteceu, vide a figura 23. Apesar de observarmos uma pequena estabilidade entre as iterações $1,0 \times 10^{8}$ e $1,9 \times 10^{8}$ isto não persistiu e o melanoma continuou a ocupar mais vértices, só entrando em um regime de crescimento menor quando já havia ocupado quase a grade inteira e em decorrência da sua taxa de mortalidade (figura 24). 


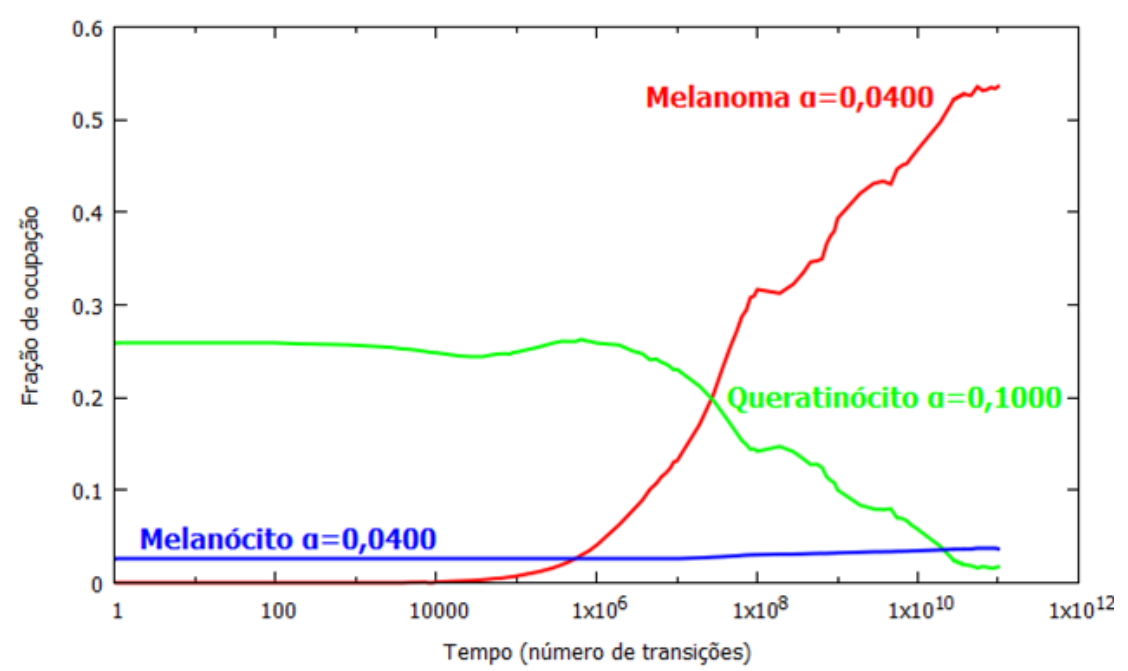

Figura 24 - Dinâmica de ocupação de simulação do tipo 3 (policlonal) com $\alpha_{2}=0,1000$, $\alpha_{1}=\alpha_{3}=0,0400$

\subsubsection{Simulação tipo 3: $\alpha_{2}=0,2600$}

Nessa simulação aumentamos em $160 \%$ a taxa de duplicação dos queratinócitos, desta forma ultrapassando os 0,2225 que era a taxa utilizada para $\alpha_{2}$ nos tipos de simulações anteriores. Como podemos observar na figura 25 , o padrão de ocupação permaneceu similar, apenas com a ocupação sendo mais rápida, isto, em virtude da taxa de duplicação do melanoma $\left(\alpha_{1}=0,040\right)$ ser maior que nos tipos de simulação anteriores, onde variou de 0,020 (4.2.2.1) até 0,035 (4.2.1.2).
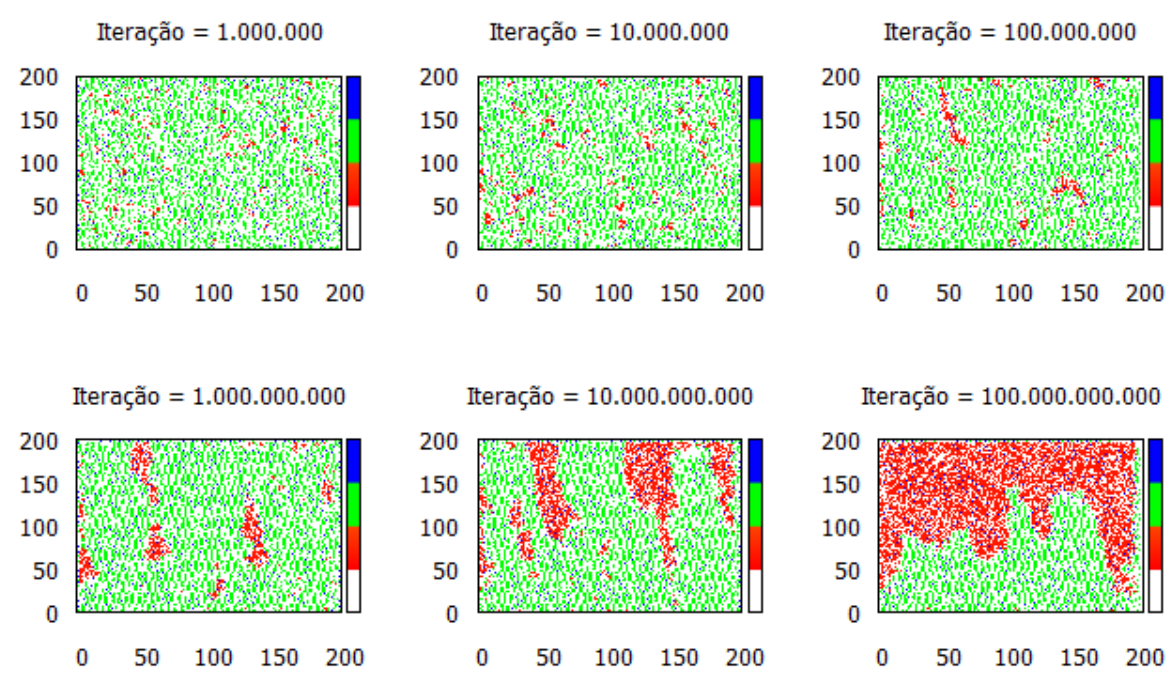

Figura 25 - Mapas de ocupação de simulação do tipo 3 (policlonal) com $\alpha_{2}=0,2600$, $\alpha_{1}=\alpha_{3}=0,04$

No gráfico da figura 26, verificamos que, após um período de relativa estabilidade da iteração $1,9 \times 10^{7}$ a $2,8 \times 10^{8}$, os melanomas voltaram a uma ocupação intensa e na iteração $1,0 \times 10^{11}$ ocupavam mais de $30 \%$ dos vértices. 


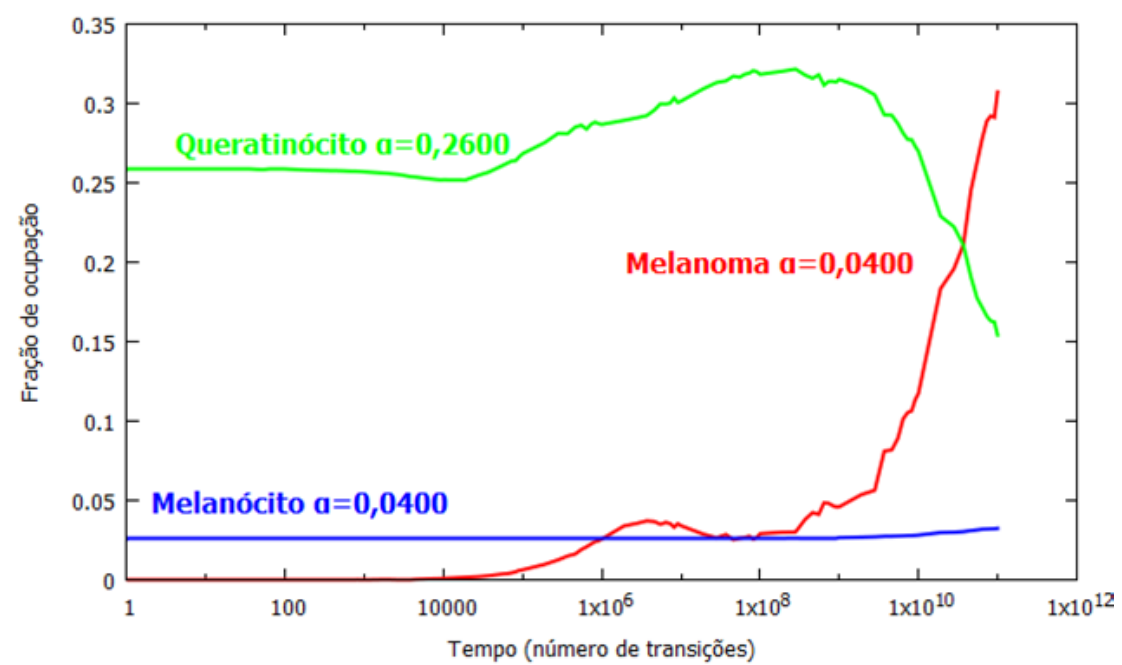

Figura 26 - Dinâmica de ocupação de simulação do tipo 3 (policlonal) com $\alpha_{2}=0,2600$, $\alpha_{1}=\alpha_{3}=0,0400$

\subsubsection{Simulação tipo 3: $\alpha_{2}=0,4000$}

Mesmo com a taxa de duplicação dos queratinócitos igual a dez vezes a taxa dos melanomas $\left(\alpha_{2}=10 \alpha_{1}\right)$, verificamos a formação de um grande agrupamento de melanomas por volta de 55 bilhões de iterações. No final da simulação de 190 bilhões de iterações, este cluster tinha persistido e aglutinado-se com outro agrupamento vizinho (figura 27).
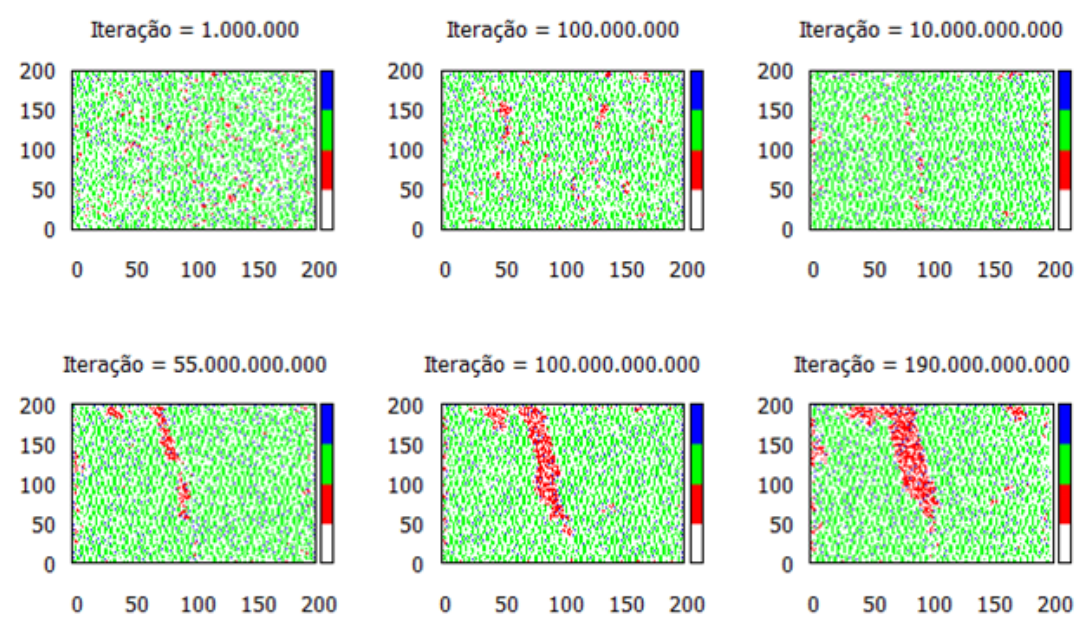

Figura 27 - Mapas de ocupação de simulação do tipo 3 (policlonal) com $\alpha_{2}=0,4000$, $\alpha_{1}=\alpha_{3}=0,04$

No gráfico da dinâmica de ocupação desta simulação, podemos notar que, após um pico da ocupação de melanomas ocorrido pouco antes de $1 \times 10^{7}$ iterações, houve um longo período de declínio somente encerrado por volta de $9,1 \times 10^{9}$, quando foi iniciado um novo período de crescimento da ocupação que se assemelha ao perfil de preponderância dos melanomas observado nas outras simulações (figura 28). 


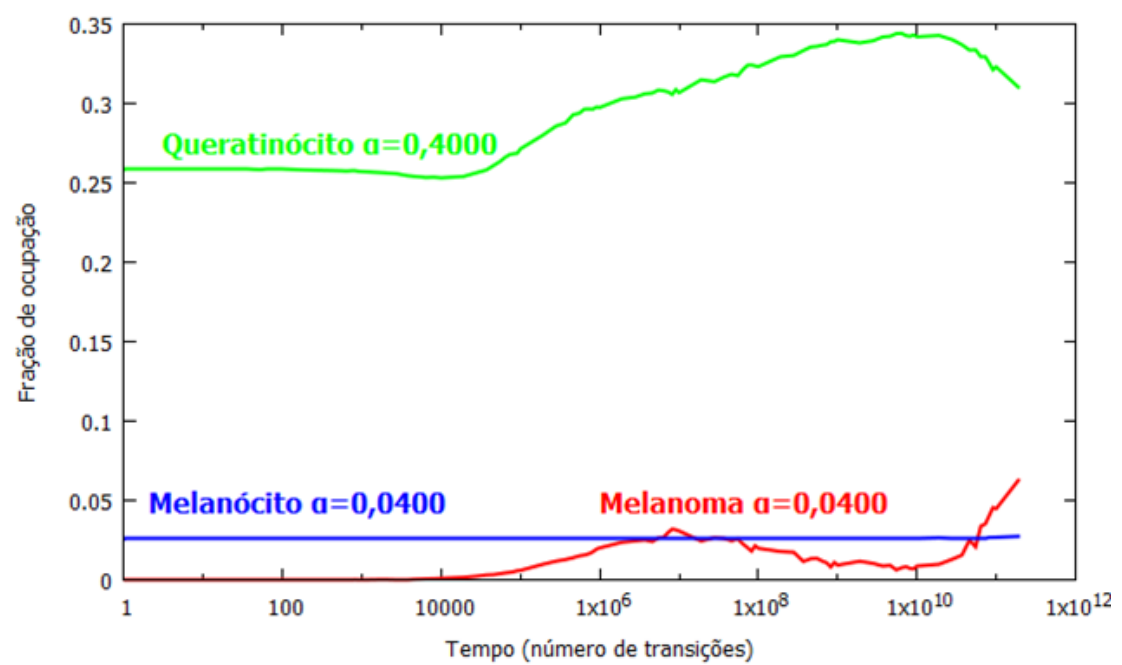

Figura 28 - Dinâmica de ocupação de simulação do tipo 3 (policlonal) com $\alpha_{2}=0,4000$, $\alpha_{1}=\alpha_{3}=0,0400$

\subsubsection{Simulação tipo 3: $\alpha_{2}=0,5000$}

Aumentando a taxa de duplicação dos queratinócitos para $\alpha_{2}=0,50$, ainda assim notamos a formação de dois agrupamentos persistentes, no alto da grade, à esquerda (a partir do mapa de ocupação da iteração $1,0 \times 10^{9}$ da figura 29) e, à direita (a partir do mapa da iteração $1,0 \times 10^{10}$ ). Porém, mesmo o da direita sendo de um tamanho significativo, verificamos apenas um pequeno adensamento deste cluster no período de $1,0 \times 10^{10}$ até $1,0 \times 10^{11}$ iterações.
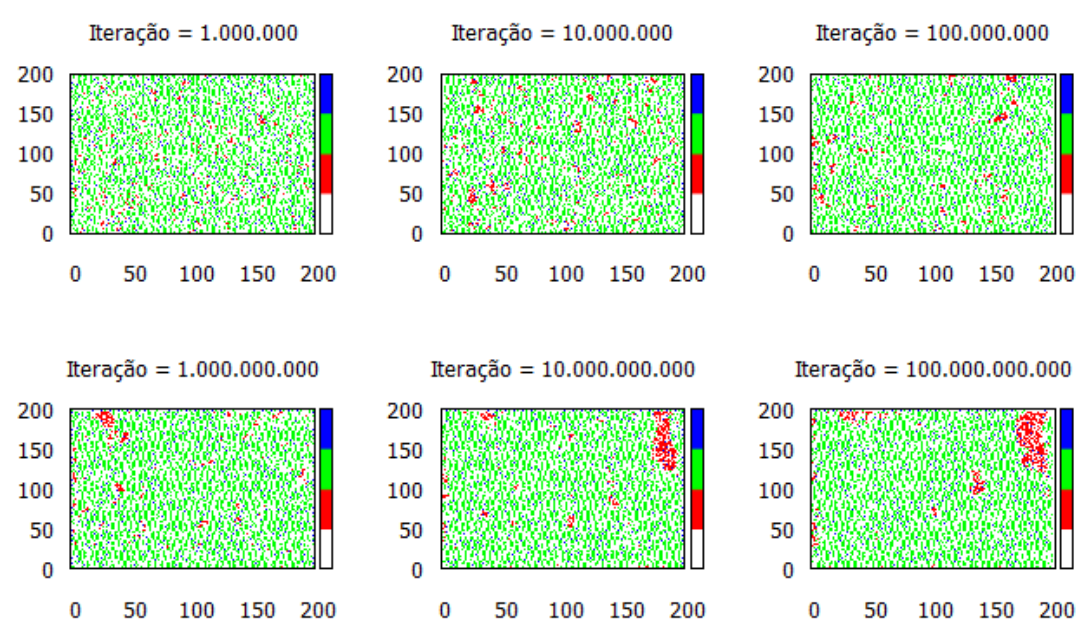

Figura 29 - Mapas de ocupação de simulação do tipo 3 (policlonal) com $\alpha_{2}=0,5000$, $\alpha_{1}=\alpha_{3}=0,04$

Essa baixa densidade pode ser explicada pelo gráfico da figura 30, onde observamos perfil semelhante ao da simulação anterior (figura 28), neste caso, porém, não ocorreu a curva de crescimento constante e, sim, uma relativa estabilidade nos períodos finais da simulação. Após um pico da ocupação de melanomas pouco acima de 3,0\% dos vértices, ocorrido por volta de $4,6 \times 10^{6}$ iterações e seguido por um pequeno período de estabilidade com ocupação 
entre $2,64 \%$ e $2,97 \%$ até $1,0 \times 10^{7}$ iterações, houve, então, um período de declínio somente encerrado por volta de $9,1 \times 10^{8}$, ponto de mínima ocupação dos melanomas nesta fase $(1,39 \%$, quando foi iniciado um novo período de crescimento da ocupação que perdurou até 4,6 $\times 10^{9}$ iterações, onde a ocupação era de $2,5 \%$. A partir daí, notamos mais dois períodos de oscilação, o primeiro até $1,9 \times 10^{10}$, oscilando entre $2,45 \%$ e $2,72 \%$ e o segundo até o final da simulação em $1,0 \times 10^{11}$ iterações, entre $2,96 \%$ e $3,32 \%$ vértices de ocupação.

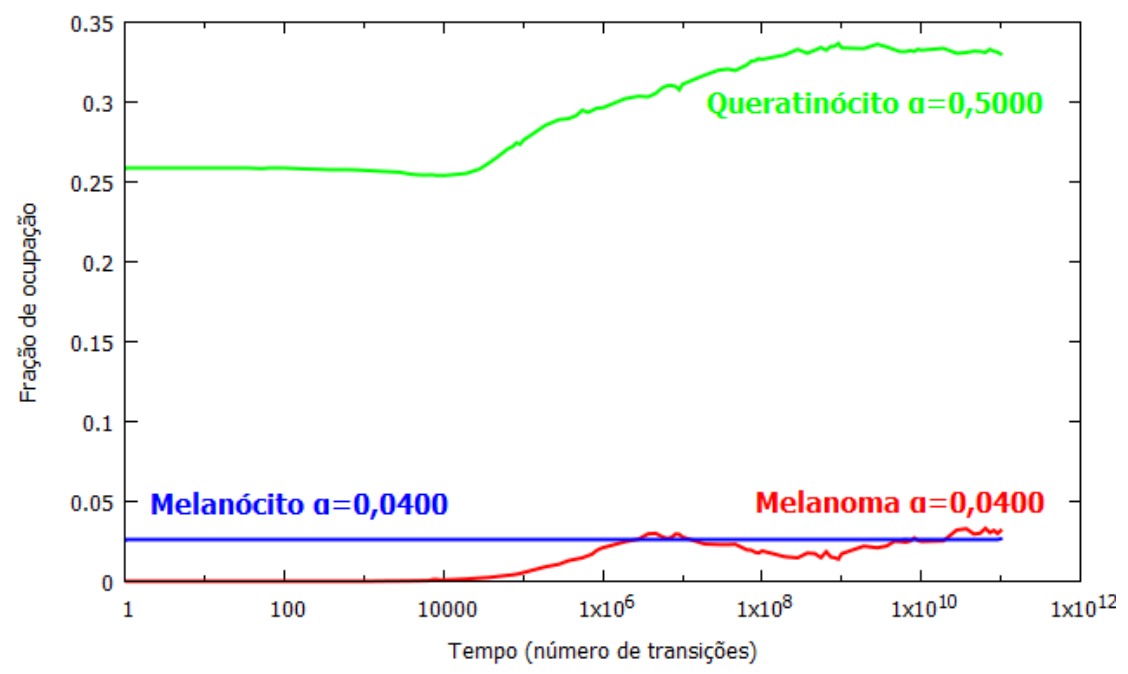

Figura 30 - Dinâmica de ocupação de simulação do tipo 3 (policlonal) com $\alpha_{2}=0,5000$, $\alpha_{1}=\alpha_{3}=0,0400$

\subsection{Resultados com melanomas, queratinócitos e com apenas um melanócito podendo gerar melanomas (monoclonal)}

Nessa classe de simulações, introduzimos um pseudotipo celular, o melanócito que pode gerar um melanoma. Nas outras simulações, qualquer elemento do tipo 3 (melanócito) podia gerar o melanoma; a partir de agora, o tipo 3 passa a representar o melanócito normal e o tipo 4 foi criado, representando o melanócito que sofreu mutação e passou também a gerar melanomas, apenas um elemento deste tipo será localizado na grade para simularmos a teoria da monoclonalidade. Será apresentado nos mapas de ocupação e gráficos com a cor preta.

4.3.1 Simulações tipo 4: monoclonal com variações de $\rho_{1}$ com $\alpha_{1}=0,4450, \alpha_{2}=0,2225$ e $\alpha_{3}=\alpha_{4}=0,0400$ fixos

Nestas simulações o melanócito gerador de melanomas foi localizado no vértice do ponto $(50,50)$ da grade. As demais taxas permaneceram as mesmas, ou seja, $\rho_{\mathbf{2}}=\mathbf{0}, \mathbf{0 2}, \rho_{\mathbf{3}}=\mathbf{0}$ e $\delta_{1}=\delta_{2}=\delta_{3}=\frac{0,46}{3}$.

\subsubsection{Simulação tipo 4: $\rho_{1}=0,0400$}

Com a taxa de mortalidade dos melanomas pouco abaixo da sua taxa de duplicação $\left(\rho_{1} / \alpha_{1} \approx 0,9\right)$, porém, com a relação entre as taxas de duplicação dos melanomas e queratinóci- 
tos igual a dois $\left(\alpha_{1} / \alpha_{2}=2,0\right)$, observamos a relativamente rápida ocupação total do interior da grade pelos melanomas por volta de $1,9 \times 10^{8}$ iterações (figura 31 ).
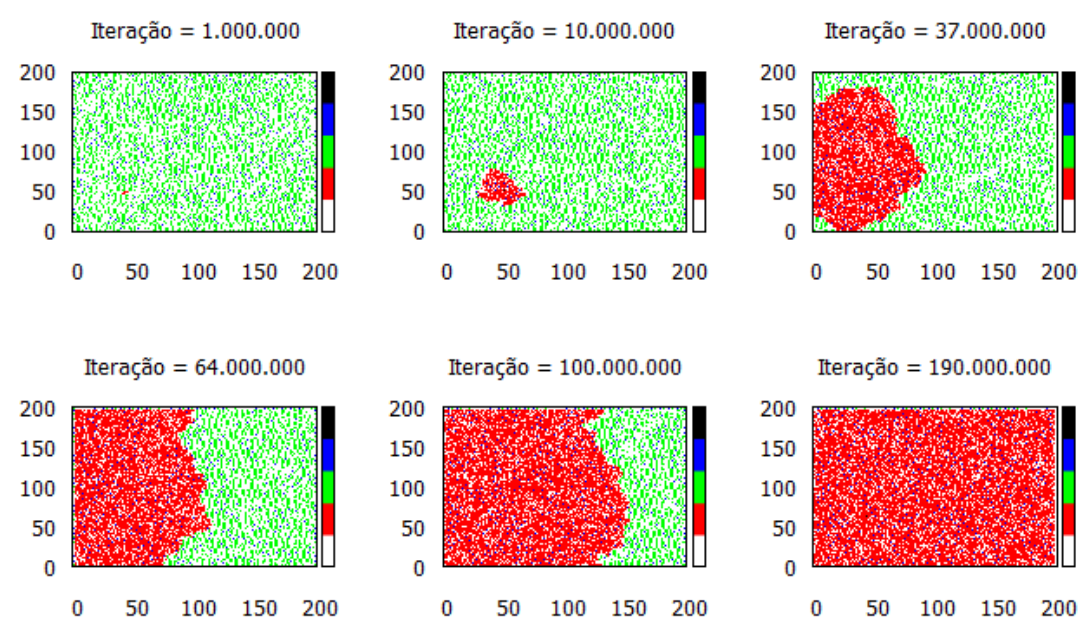

Figura 31 - Mapas de ocupação de simulação do tipo 4 (monoclonal) com $\rho_{1}=0,0400$ e $\alpha_{1}=0,4450, \alpha_{2}=0,2225$ e $\alpha_{3}=\alpha_{4}=0,0400$

Até por volta da iteração $6,4 \times 10^{5}$ a ocupação dos melanomas era insignificativa, quando alcançou pela primeira vez, o ainda pequeno, número de 4 vértices ocupados $(0,0125 \%)$, porém, após uma oscilação entre 4 e 5 vértices ocupados, na $1,0 \times 10^{6}$ iteração alcançou $0,0300 \%$ de ocupação e não parou mais de crescer até alcançar 72,12\%, quando passou a oscilar entre $71,50 \%$ e $72,02 \%$ de ocupação até o final da simulação em $1,0 \times 10^{10}$ iterações (figura 32).

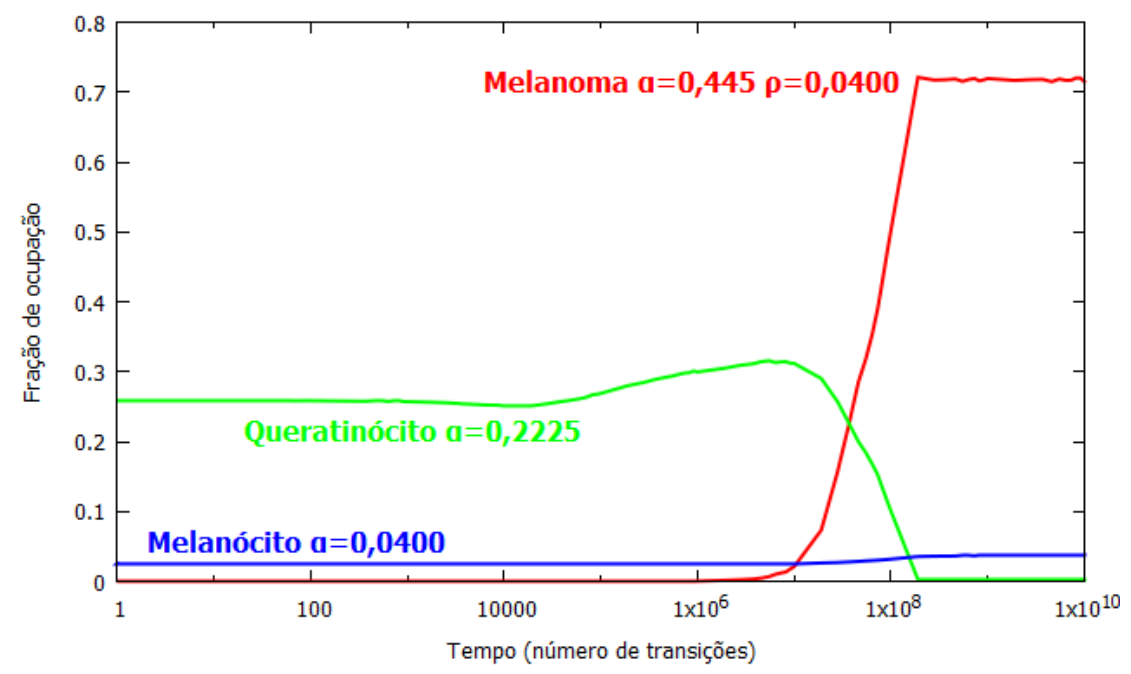

Figura 32 - Dinâmica de ocupação de simulação do tipo 4 (monoclonal) com $\rho_{1}=0,0400$ e $\alpha_{1}=0,4450, \alpha_{2}=0,2225$ e $\alpha_{3}=\alpha_{4}=0,0400$

\subsubsection{Simulação tipo 4: $\rho_{1}=0,2000$}

Agora, com a taxa de mortalidade dos melanomas pouco menor que a metade da sua taxa de duplicação $\left(\rho_{1} / \alpha_{1} \approx 0,45\right)$. Observamos ocupação do interior da grade pelos melanomas 
bem menor se comparada à da simulação anterior (figura 31). Enquanto naquela tínhamos, após $1,0 \times 10^{8}$ iterações, a impressão visual de quase $\frac{2}{3}$ dos vértices ocupados (na realidade pouco mais de 50\%), nesta simulação não se chega a ocupar um retângulo de $25 \times 100$ (base por altura), de fato, ocupava-se nesta altura da dinâmica cerca de $4,2 \%$ dos vértices. No final da simulação, após $1,0 \times 10^{11}$ iterações, tem-se $21,7 \%$ aproximadamente de ocupação dos vértices pelos melanócitos (cerca de 25\% aparentemente).
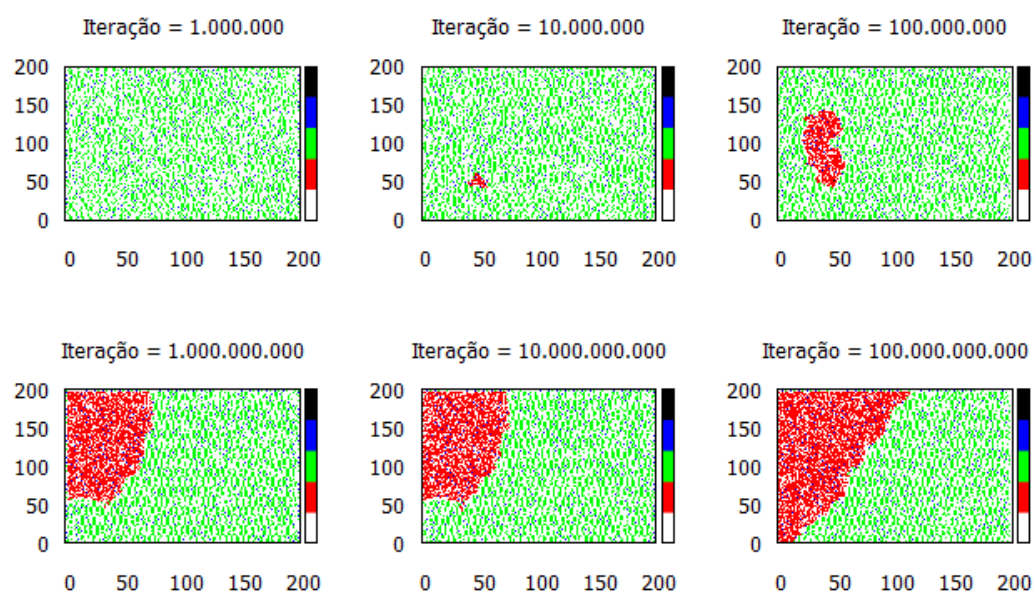

Figura 33 - Mapas de ocupação de simulação do tipo 4 (monoclonal) com $\rho_{1}=0,2000$ e $\alpha_{1}=0,4450, \alpha_{2}=0,2225$ e $\alpha_{3}=\alpha_{4}=0,0400$

No gráfico da figura 34, observamos perfil parecido com a simulação da seção anterior (4.3.1.1 - figura 32), porém, aqui nesta simulação, ocorre um aumento menor da ocupação dos melanomas a partir de $1,9 \times 10^{8}$ e são verificadas oscilações mais intensas nesta ocupação, apesar de sempre ser mantida a tendência de crescimento (figura 34).

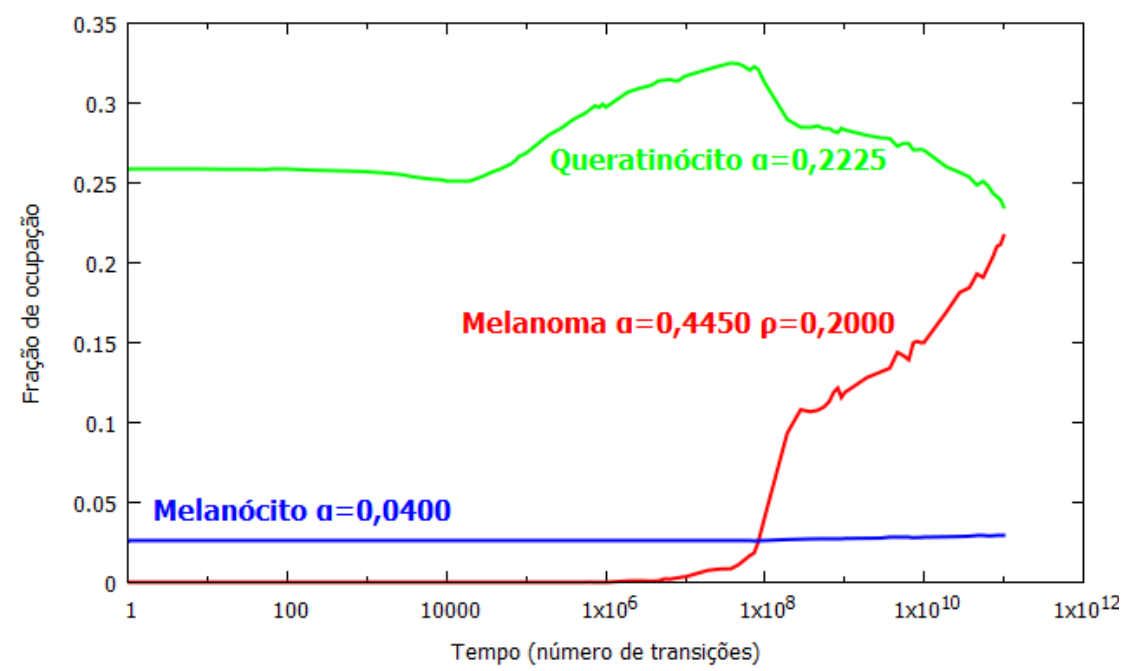

Figura 34 - Dinâmica de ocupação de simulação do tipo 4 (monoclonal) com $\rho_{1}=0,2000$ e $\alpha_{1}=0,4450, \alpha_{2}=0,2225$ e $\alpha_{3}=\alpha_{4}=0,0400$ 
4.3.2 Simulações tipo 5: monoclonal com variações de $\rho_{1}$ com $\alpha_{1}=0,0445, \alpha_{2}=0,2225$ e $\alpha_{3}=\alpha_{4}=0,0400$ fixos

Nesta série de simulações baixamos a taxa de duplicação dos melanomas de forma que a relação entre as taxas de duplicação dos melanomas e queratinócitos fosse igual a $20 \%$ $\left(\alpha_{1} / \alpha_{2}=0,2\right)$. As demais taxas permaneceram as mesmas, ou seja, $\rho_{\mathbf{2}}=\mathbf{0}, \mathbf{0 2}, \rho_{\mathbf{3}}=\mathbf{0}$ e $\delta_{1}=\delta_{2}=\delta_{3}=\frac{0,46}{3}$.
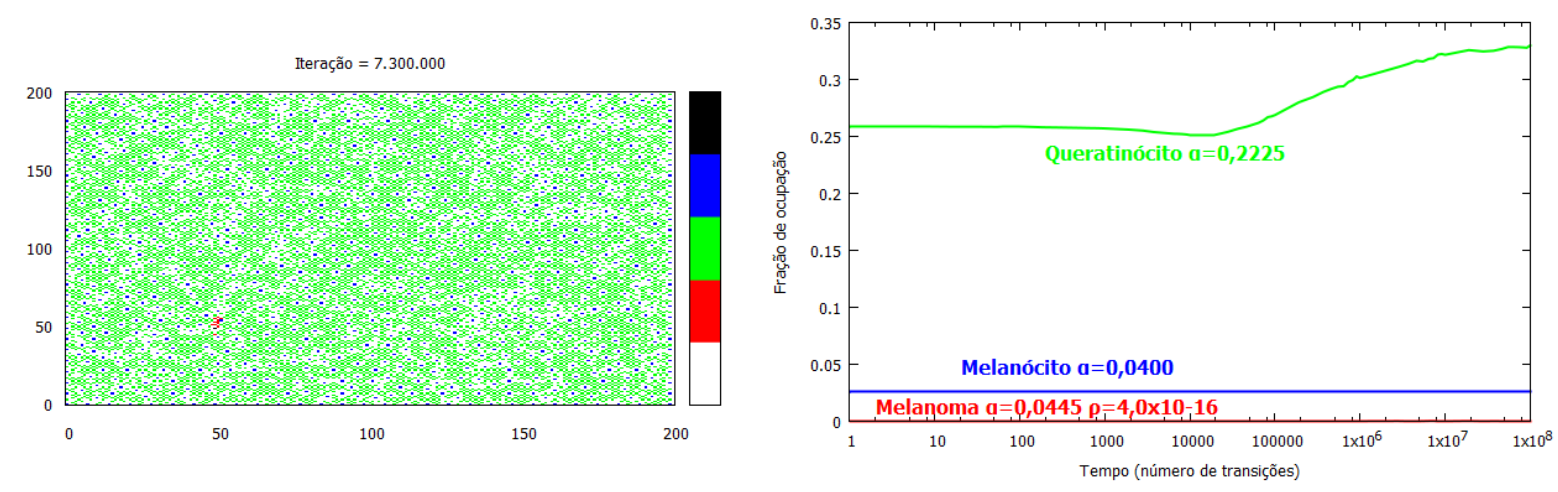

Figura 35 - Mapa e dinâmica de ocupação de simulação do tipo 5 (monoclonal) $\operatorname{com} \rho_{1}=$ $4,0 \times 10^{-16}$ e $\alpha_{1}=0,0445, \alpha_{2}=0,2225$ e $\alpha_{3}=\alpha_{4}=0,0400$

\subsubsection{Simulação tipo 5: $\rho_{1}=4,0 \times 10^{-16}$}

Nesta série de simulações o melanócito gerador de melanomas ainda estava localizado no vértice do ponto $(50,50)$ da grade. Verifica-se que, mesmo com a relação da taxa de mortalidade e a taxa de duplicação da ordem de $9,0 \times 10^{-15}$, os melanomas não ultrapassam a ocupação de 11 vértices, o que foi alcançado apenas uma vez, nos instantes capturados do período analisado (até 100 milhões de iterações), após 7,3 milhões de iterações, veja na figura 35 a pequena mancha avermelhada próxima à posição $(50,50)$.

\subsubsection{Simulação tipo 5: $\rho_{1}=0,0$}

Agora com o melanócito mutado situado no vértice de posição $(100,100)$ e com a taxa de mortalidade dos melanomas igual a zero, verificamos o natural maior adensamento de melanoma, ocupando cerca de $93,5 \%$ dos vértices por volta de 50 milhões de iterações.

No gráfico da figura 37, notamos o rápido crescimento da ocupação sem oscilações e com quase imperceptíveis mudanças na inclinação da curva de ocupação.

Apresentamos no próximo capítulo as conclusões e as perspectivas de pesquisa abertas por esses resultados observados. 

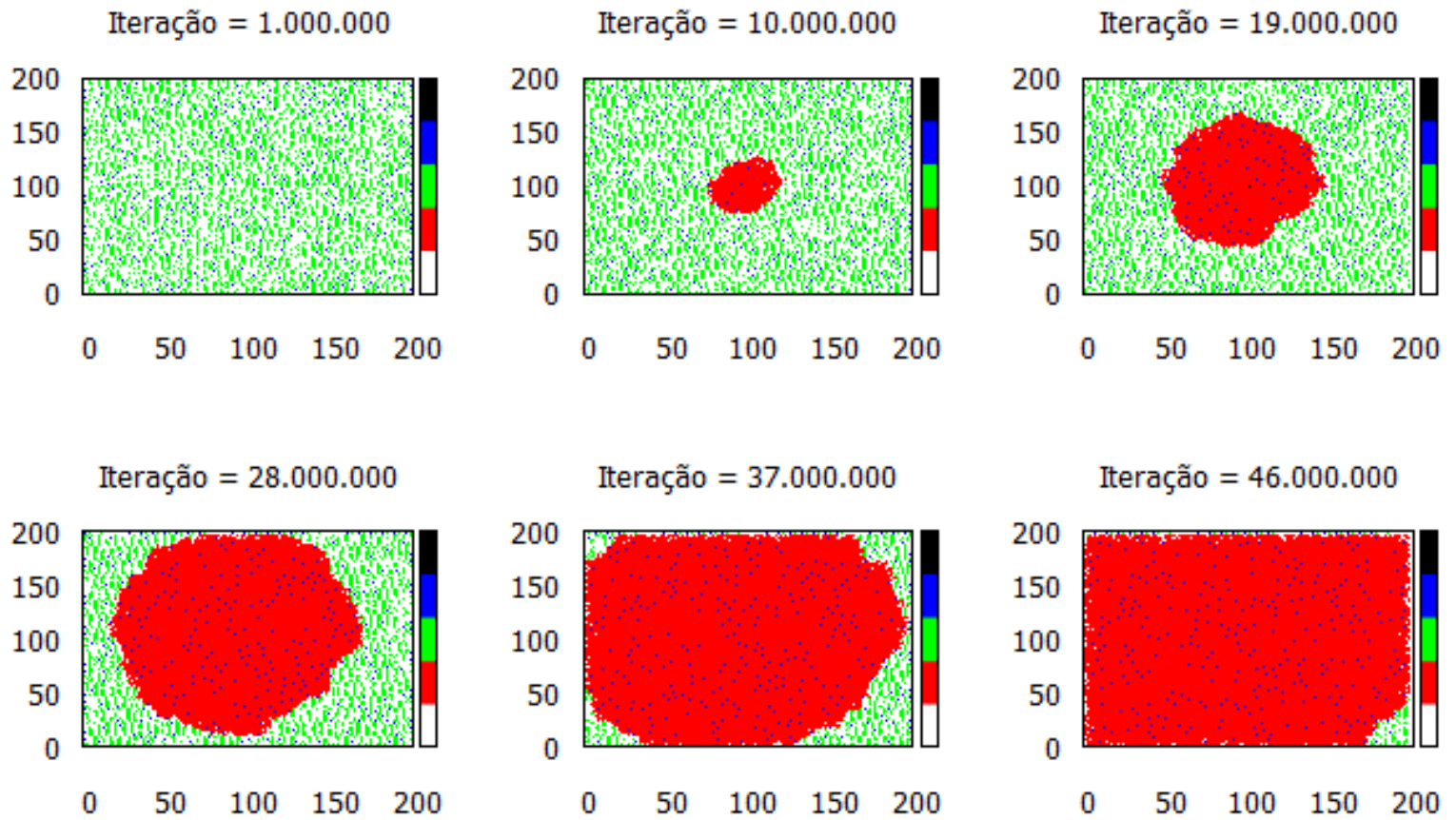

Figura 36 - Mapas de ocupação de simulação do tipo 5 (monoclonal) com $\rho_{1}=0,0$ e $\alpha_{1}=$ $0,0445, \alpha_{2}=0,2225$ e $\alpha_{3}=\alpha_{4}=0,0400$

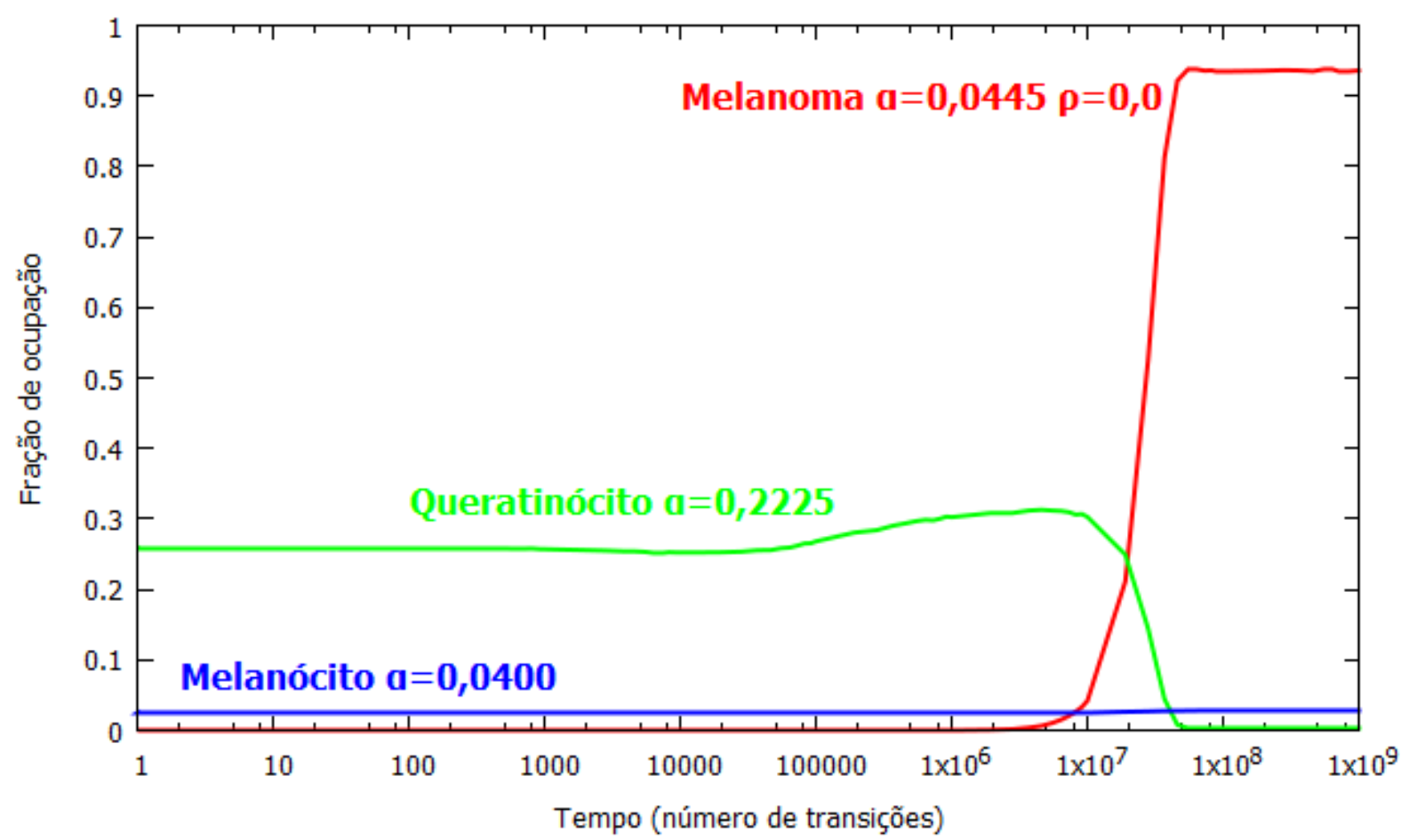

Figura 37 - Dinâmica de ocupação de simulação do tipo 5 (monoclonal) com $\rho_{1}=0,0$ e $\alpha_{1}=0,0445, \alpha_{2}=0,2225$ e $\alpha_{3}=\alpha_{4}=0,0400$ 


\section{PERSPECTIVAS E CONCLUSÃO}

Nas simulações realizadas ficou muito clara a força de proliferação fornecida pela perda de inibição por contato, representada pelo diâmetro de exclusão menor no nosso modelo. Em uma análise simples, nota-se que a predominância dos melanomas começa a ser construída quando este tipo celular alcança a ocupação de apenas $4 \%$ dos vértices. A partir daí acontece, invariavelmente, um crescimento quase constante do preenchimento da grade por este tipo celular, com poucos períodos de estabilidade. Isto acontece mesmo quando temos a taxa de mortalidade do melanoma igual à sua taxa de duplicação (simulação 4.2.2.1) e, na única oportunidade em que a ocupação do melanoma não ultrapassou esse limiar, na simulação 4.2.3.4, a ocupação pelos queratinócitos encontrou um equilíbrio, oscilando entre $33,05 \%$ e $33,68 \%$ dos vértices da grade, a partir de cerca de $2,8 \times 10^{8}$ iterações até o final dessa simulação em $1,0 \times 10^{11}$ iterações; enquanto a dos melanomas ficou oscilando entre $1,39 \%$ e 3,32\%.

Da mesma forma, a influência da falta da inibição por contato parece tornar quase inevitável a preponderância do melanoma, isso foi verificado, por exemplo, quando deixamos fixa a relação da taxa de mortalidade por taxa de duplicação dos melanomas $\left(\rho_{1} / \alpha_{1}\right)$ em $50 \%$, como foi o caso das simulações tipo 3 da seção 4.2.3. Nesta série de simulações notamos que, só quando a taxa de duplicação dos queratinócitos $\left(\alpha_{2}\right)$ subiu ao valor de 0,50 , deixando então, a relação $\rho_{2} / \alpha_{2}$ em $4,0 \%$ e a relação entre as taxas de duplicação dos melanomas pela dos queratinócitos $\left(\alpha_{1} / \alpha_{2}\right)$ em apenas $8 \%$, houve, então, uma relativa coexistência entre os dois tipos celulares, relativa porque observada, ao menos, até $1,0 \times 10^{11}$ iterações. A mesma coisa aconteceu nos outros dois tipos de simulação policlonal, das seções 4.2.1 e 4.2.2, nestas oportunidades, mantivemos fixa a relação da taxa de mortalidade por taxa de duplicação dos queratinócitos, $\rho_{2} / \alpha_{2} \approx 9 \%$ e, como já mencionado acima, nem mesmo na simulação com a relação $\rho_{1} / \alpha_{1}=1,0$, observou-se uma escalada com menor intensidade da ocupação dos melanomas, apenas um atraso no seu início.

Nas simulações da seção 4.3 em que utilizamos a teoria de origem monoclonal dos cânceres, o intuito foi o de aprofundar a pesquisa do controle de transição introduzido por nós no modelo, que pode simular, entre outras coisas, o mecanismo de mutação. Os resultados foram satisfatórios e observamos, o que era esperado por ser única a origem dos melanomas, uma maior dependência do crescimento da ocupação do melanoma à relação taxa de mortalidade por taxa de duplicação. Mesmo com esta relação muita pequena na simulação 4.3.2.1, $\rho_{1} / \alpha_{1} \approx 9,0 \times 10^{-15}$, os melanomas não conseguiram progredir com uma taxa de duplicação igual a $20 \%$ da taxa dos queratinócitos. Observamos também, que com taxas de duplicação altas, mesmo com essa origem única dos melanomas, a ocupação da grade é inevitável, apenas uma questão de tempo. Não foi verificado nas nossas simulações um caso de coexistência entre melanomas e queratinócitos.

Estes resultados trazem perspectivas de exploração no design de novos experimentos 
laboratoriais como, por exemplo, uma, talvez possível, cocultura entre melanócitos e queratinócitos onde, em algum momento e com alguma probabilidade, fosse incluído o melanoma para a observação da nova dinâmica de ocupação. Uma outra perspectiva seria a de generalizar o nosso modelo para simulação de espaços tridimensionais, dessa forma, suas simulações poderiam ser utilizadas para auxiliar a criação ou a melhoria de modelos de desenvolvimento de melanomas em camundongos.

Durante o projeto de pesquisa surgiram ainda outros caminhos que experimentamos trilhar, como aquele do modelo que desenvolvemos com acoplamento à simulação de difusão de um fármaco que agia diminuindo as probabilidades — ainda não trabalhávamos com taxas na ocasião do desenvolvimento do protótipo — de duplicação dos melanomas. Simulações foram realizadas também com mais tipos celulares, como foi o caso da inclusão das células de Merkel, também presentes na camada basal da epiderme, e dos queratinócitos "alelofílicos" aos melanomas, observados nos experimentos realizados pelo nosso grupo e relatados em artigo de Morais et al. (2017) a ser submetido com nossa coautoria (fac-símile da primeira página no anexo A). Dessa forma, começamos a analisar os resultados dessa generalização para quatro tipos celulares ou mais $(q \geq 4)$. 


\section{REFERÊNCIAS}

AAD, American Academy of Dermatology. Skin cancer. Washington, D.C., USA: American Academy of Dermatology, 2016. Disponível em: <https://www.aad.org/media/stats/conditions/ skin-cancer>.

ABRAHAMSOHN, Paulo A. MOL Microscopia OnLine - guia interativo de histologia. Instituto de Ciências Biomédicas - Universidade de São Paulo, 2008. Disponível em: <http: //www.icb.usp.br/mol/0indicedemodulos.html>.

ACS, American Cancer Society. Cancer Facts \& Figures 2016. Atlanta, GA, USA: American Cancer Society, 2016.

ALBERTS, Bruce et al. Câncer. In: Biologia molecular da célula. 5. ed. Porto Alegre: Artmed Editora, 2015. cap. 20. ISBN 9788536320663.

ANANTHAKRISHNAN, Revathi; EHRLICHER, Allen. The forces behind cell movement. Int J Biol Sci, v. 3, n. 5, p. 303-317, 2007.

BARBOSA, Fernanda Souza. Modelo de impedância de ordem fracional para a resposta inflamatória cutânea. Rio de Janeiro: Dissertação (Mestrado em Engenharia Biomédica) Universidade Federal do Rio de Janeiro, 2011. 107 p.

CICHOREK, Mirosława et al. Skin melanocytes: biology and development. Postepy Dermatol Alergol, v. 30, n. 1, p. 30-41, 2013.

ESTRELLA, Veronica et al. Acidity generated by the tumor microenvironment drives local invasion. Cancer research, v. 73, n. 5, p. 1524-1535, 2013.

GATENBY, Robert A.; FRIEDEN, B. Roy. Application of information theory and extreme physical information to carcinogenesis. Cancer Research, v. 62, n. 13, p. 3675-3684, 2002.

The critical roles of information and nonequilibrium thermodynamics in evolution of living systems. Bulletin of mathematical biology, v. 75, n. 4, p. 589-601, 2013.

GATENBY, Robert A. et al. Acid-mediated tumor invasion: a multidisciplinary study. Cancer Research, v. 66, n. 10, p. 5216-5223, 2006.

GATENBY, Robert A.; GILLIES, Robert J. Why do cancers have high aerobic glycolysis? Nature Reviews Cancer, v. 4, n. 11, p. 891-899, 2004.

GATENBY, Robert A.; MAINI, Philip K. Mathematical oncology: Cancer summed up. Nature, v. 421, n. 6921, p. 321-321, 2003.

GATENBY, Robert A. et al. Cellular adaptations to hypoxia and acidosis during somatic evolution of breast cancer. British journal of Cancer, v. 97, n. 5, p. 646-653, 2007.

GATENBY, Robert A.; VINCENT, Thomas L. An evolutionary model of carcinogenesis. Cancer Research, v. 63, n. 19, p. 6212-6220, 2003.

GAWKRODGER, D.; ARDERN-JONES, M.R. Dermatology: An Illustrated Colour Text. Elsevier Health Sciences UK, 2016. (Illustrated Colour Text). ISBN 9780702068546. Disponível em: <https://books.google.com.br/books?id=YkPUDAAAQBAJ>. 
HAHN, William C; WEINBERG, Robert A. Modelling the molecular circuitry of cancer. Nature Reviews Cancer, Nature Publishing Group, v. 2, n. 5, p. 331-341, 2002a.

. Rules for making human tumor cells. New England Journal of Medicine, Mass Medical Soc, v. 347, n. 20, p. 1593-1603, 2002 b.

HANAHAN, Douglas; WEINBERG, Robert A. Hallmarks of cancer: the next generation. cell, v. 144, p. 646-674, 2011.

HECKMAN, Carol A. Contact inhibition revisited. Journal of cellular physiology, Wiley Online Library, v. 220, n. 3, p. 574-575, 2009.

HIELSCHER, Abigail; WIRTZ, D. A physical sciences network characterization of nontumorigenic and metastatic cells. Scientific reports, v. 3, 2013.

HOUAISS, Instituto Antônio. Grande Dicionário Houaiss. 2017. Disponível em: <https:// houaiss.uol.com.br/pub/apps/www/v3-0/html/index.htm\#0>.

INCA, Instituto Nacional de Câncer José Alencar Gomes da Silva. Estimativa 2016: Incidência do Câncer no Brasil. Rio de Janeiro, 2015.

Tipos de câncer: pele melanoma. 2016. Disponível em: <http://www2.inca.gov.br/wps/ $\mathrm{wcm} /$ connect/tiposdecancer/site/home/pele_melanoma/definicao $>$.

KARP, G. Biologia celular e molecular. MANOLE, 2005. ISBN 9788520415931. Disponível em: <https://books.google.com.br/books?id=4qpeIwPEixoC $>$.

KUMAR, V.; ASTER, J.C.; ABBAS, A. Robbins \& Cotran Patologia - Bases Patológicas das Doenças. Elsevier Brasil, 2015. ISBN 9788535255775. Disponível em: <https://books.google. com.br/books?id=WhpQDAAAQBAJ $>$.

LIU, Liyu et al. Minimization of thermodynamic costs in cancer cell invasion. Proceedings of the National Academy of Sciences, v. 110, n. 5, p. 1686-1691, 2013.

MAZEL, Alexandre; SUHOV, Yuri; STUHL, Izabella. A classical wr model with q particle types. Journal of Statistical Physics, v. 159, n. 5, p. 1040-1086, 2015.

MAZEL, Alexandre et al. Dominance of most tolerant species in multi-type lattice widom-rowlinson models. Journal of Statistical Mechanics: Theory and Experiment, v. 2014, n. 8, p. P08010, 2014.

MONTANARI, Tatiana. Histologia: texto, atlas e roteiro de aulas práticas [recurso eletrônico]/Tatiana Montanari. 3. ed. Porto Alegre: Edição do Autor, 2016. 229 p. : digital.

MORAIS, Mauro Cesar Cafundó de et al. Stochastic model of contact inhibition and the proliferation of melanoma in situ. 2017.

ORLANDO, Paul A.; GATENBY, Robert A.; BROWN, Joel S. Tumor evolution in space: the effects of competition colonization tradeoffs on tumor invasion dynamics. Frontiers in oncology, v. 3, p. 45, 2013.

PIENTA, Kenneth J. Modeling cancer as a complex adaptive system: Genetic instability and evolution. In: DEISBOECK, Thomas S.; KRESH, J. Yasha (Ed.). Complex Systems Science in Biomedicine. Boston, MA: Springer US, 2006. cap. 6.1, p. 537-556. 
PINHO, Márcio Sarroglia. Histórico da Linguagem C. Pontifícia Universidade Católica do Rio Grande do Sul, 1990. Disponível em: <http://www.inf.pucrs.br/ pinho/LaproI/Historico/ Historico.htm>.

RIETMAN, Edward A. et al. An integrated multidisciplinary model describing initiation of cancer and the warburg hypothesis. Theoretical Biology and Medical Modelling, v. 10, n. 1, p. $1,2013$.

SAITO, Renata de Freitas et al. (Ed.). Fundamentos de oncologia molecular. São Paulo: Editora Atheneu, 2015.

SALVIO, Ana Gabriela et al. Experiência de um ano de modelo de programa de prevenção contínua do melanoma na cidade de Jaú-SP, Brasil. Anais Brasileiros de Dermatologia, v. 86, n. 4, p. 669-74, 2011.

SILVA, Rodrigo Ribeiro da. O gene KIAA0090 é ativado em lesão pré-neoplásica e seu silenciamento por siRNA causa morte celular em linhagem de melanoma. Ribeirão Preto: Dissertação (Mestrado em Biologia Celular e Molecular) - Universidade de São Paulo, 2010. $90 \mathrm{p}$.

SIMõES, Ricardo Santos et al. Etimologia de termos Morfológicos. Universidade Federal de São Paulo - UNIFESP, 2014. Disponível em: <http://www2.unifesp.br/dmorfo/Prof\% 20Manoel\%20Histologia/Dicionario\%20etimologico.pdf>.

SMALLBONE, Kieran et al. Metabolic changes during carcinogenesis: potential impact on invasiveness. Journal of theoretical biology, v. 244, n. 4, p. 703-713, 2007.

SOLÉ, Ricard V.; GARCÍA, Isabel González; COSTA, José. Spatial dynamics in cancer. In: DEISBOECK, Thomas S.; KRESH, J. Yasha (Ed.). Complex Systems Science in Biomedicine. Boston, MA: Springer US, 2006. cap. 6.2, p. 557-572.

SOUZA, Sonia RP de; FISCHER, Frida M; SOUZA, José MP de. Bronzeamento e risco de melanoma cutâneo: revisão da literatura. Revista de Saúde Pública, SciELO Brasil, v. 38, n. 4, p. 588-598, 2004.

STANDRING, Susan. Grays anatomia 40a edição. Elsevier Brasil, 2010. ISBN 9788535246247. Disponível em: <https://books.google.com.br/books?id=bJP2VMQGNLQC>.

TOLEDO, Denise Caroline. Fatores genéticos e moleculares relacionados ao melanoma. 2012. Disponível em: <http://ppgca.evz.ufg.br>.

TOMASETTI, Cristian; VOGELSTEIN, Bert. Variation in cancer risk among tissues can be explained by the number of stem cell divisions. Science, v. 347, n. 6217, p. 78-81, 2015.

WEINBERG, R.A. A Biologia do Câncer. Porto Alegre: Artmed, 2016. ISBN 9788536315683. Disponível em: <https://books.google.com.br/books?id=KAWpDAAAQBAJ>.

WELLER, Richard P. et al. Clinical dermatology. 4th. ed. Massachusets: Blackwell Publishing, 2008 .

WIDOM, Benjamin; ROWLINSON, John S. New model for the study of liquid-vapor phase transitions. The Journal of Chemical Physics, v. 52, n. 4, p. 1670-1684, 1970. 
ZAIDI, M Raza; DAY, Chi-Ping; MERLINO, Glenn. From uvs to metastases: modeling melanoma initiation and progression in the mouse. Journal of Investigative Dermatology, Nature Publishing Group, v. 128, n. 10, p. 2381-2391, 2008. 


\section{ANEXO A - MANUSCRITO DE NOSSA COAUTORIA (AINDA A SER SUBMETIDO)}

\section{Stochastic model of contact inhibition and the proliferation of melanoma in situ}

Mauro Cesar Cafundó de Morais ${ }^{\mathrm{a}, \mathrm{b}}$, Izabella Stuhl ${ }^{\mathrm{d}}$, Alan Utsuni Sabino ${ }^{\mathrm{b}}$, Willian Wagner Lautenschlager ${ }^{\mathrm{b}}$, Alexandre Sarmento Queiroga ${ }^{\mathrm{a}}$, Tharcisio Citrangulo Tortelli $\mathrm{Jr}^{\mathrm{a}}$, Roger Chammas ${ }^{\mathrm{a}}$, Yuri Suhov ${ }^{\mathrm{c}}$, and Alexandre Ferreira Ramos ${ }^{\mathrm{a}, \mathrm{b},{ }^{*}}$

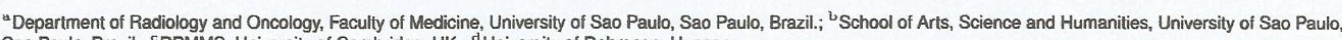
Sao Paulo, Brazil.; 'DPMMS, University of Cambridge, UK.; ' University of Debrecen, Hungary.

This manuscript was compiled on January 23, 2017

Contact inhibition is a central feature orchestrating cell proliferation in culture experiments with its loss being associated with malignant transformation and tumorigenesis. We performed a co-culture experiment with human metastatic melanoma cell line (SK-MEL-147) and immortalized keratinocyte cells (HaCaT), and after 8 days it was detected a spatial pattern characterized by the formation of clusters of melanoma cells surrounded by keratinocytes constraining their proliferation. In addition, we noticed that the proportion of melanoma cells within the total population has increased. To describe our results we propose a spatial stochastic model (based on WidowRowlinson model) considering cell prollferation, death, migration, and cell-to-cell interaction through contact inhibition. Our theoretical results demonstrate that loss of contact inhibition is a sufficient mechanism to explain the increase on the proportion of tumor cells and the spatial patterns that we observed experimentally.

keratinocyte | melanoma | co-culture proliferation | contact-inhibition | stochastic dynamics

\section{Introduction}

espite the accumulated knowledge of experimental inves tigation on contact inhibition as an in vitro manifestation of homeostatic cell density control in normal tissues the use of quantitative tools to understand its role on the growth of cancer in situ is only in its infancy $[1,2]$. Contact inhibition is defined as the decrease of proliferation rates when the cell density incrcascs. At the molccular level, intcrcellular adhesion mediated by E-cadherin (CDH1) serves as negative regulator of the cell proliferation signal by recruiting $\beta$-catenin to adherens junctions and thus repressing the transcriptional activation of proliferative gencs [3]. Another mechanism is illustrated by the interplay of the cyclin-dependent kinase inhibitors p27 and $\mathrm{p} 16$, tumor suppressor proteins. In a recent experiment, it has becn demonstrated that p16 is responsible for a stronger sensitivity to contact inhibition in combination to p27 [4] and that has provided a clue about the cancer resistance of naked molerats as compared to human and murine fibroblasts. While in human and murine fibroblasts, p16 expression is attenuated when cell density increases, coordinated expression of both p16 and p27 in naked mole rat fibroblasts rendered these cells more resistant to malignant transformation. Naked mole rat fibroblast growth is strongly inhibitcd by cell to cell contact, while growth of human and murine fibroblasts is supported even in higher densities. Here, we propose that cells whose growth overcome contact inhbition, i.e. tolerate higher cellular densities, are more resistant to allelopathic effects of their neighbours, and are therefore called allelophylic (allelo, the other; phylia, affinity). The proposition of a theoretical model that accounts for different degrees of contact inhibition and quantifies its role on carcinogenesis is therefore necessary

Mathematical models have becn helpful for the analysis of high throughput data [5-7], identification of tumorigenesis [8-12], angiogenesis [13], cancer invasiveness [14-16], therapy design [ 1721$]$, or for the detection of the effects of intrinsic randomness of cellular phenomena on cancer [11, 22]. New theoretical approaches have been developed to show that contact inhibition happens through both cell to cell contact and mechanical constraints that diminish cell to substrate adhesion area [23]. In this manuscript we present a theorctical and experimental framework dedicated to investigate modulated contact inhibition and its role on the formation of a carcinoma in situ and demonstrate that allelophilic properties of cancer cells is a key feature for their uncontrolled proliferation.

\section{Results}

R1. Keratinocytes and melanoma cells co-culture proliferation To evaluate cell proliferation the human metastatic melanoma (SK-MEL-147) and human immortalized keratinocytes (Ha$\mathrm{CaT}$ ) cell lines were selected for co-culture experiments. These cells mimic the interaction between the skin basal layer cells and melanoma. Another reason we selected these cell lines

\section{Significance Statement}

This work provides results of a quantitative study of the impact of contact inhibition upon formation and growth of tumor-like melanoma cell clusters in a co-culture with keratinocyte. We propose a new mathematical model of such development based on stochastic dynamics represented by a Markov chain with specified transitions. Transitions include cell division, death and migration; the key feature of the model is a collection of exclusion distances between cells of given types ("normal" and cancer). Keratinocytes have a larger exclusion diameter manifesting a higher degree of contact inhibition compared with cancer cells having a shorter exclusion diameter. We compare experimental results observed in the cell co-culture and numerical simulation results based on the proposed mathematical model. The degree of agreement between these allows us to conclude that the exclusion distances are of a significant importance for the analysis of development of melanoma in situ. Consequently, the measurement of the level of contact inhibition betweeen "normal" and cancer cells might be useful for cancer in situ diagnostics, and use of drugs that increase such a degree for cancer cells may be effective in its treatment.

The authors declare no conflict of interest. 


\section{APÊNDICE A - ALGORITMO DO SIMULADOR}

O programa do nosso modelo foi chamado de ODyn, abreviatura do inglês Occupation Dynamics, porque no início sempre partíamos de uma grade vazia, apenas com as bordas preenchidas (condições de contorno) para a observação da dinâmica de ocupação, depois foi implementado o início a partir de uma configuração de ocupação parcial ou total. É um programa escrito na linguagem $C$, que é considerada uma linguagem de médio nível - assim chamada pela distância da linguagem mais próxima da linguagem de máquina, ou linguagem de baixo nível - porque mistura elementos de alto nível, mais próximos da linguagem natural, com características de linguagens de baixo nível, por exemplo, o acesso aos registros do sistema ou o trabalho com endereços de memória.

A linguagem $\mathrm{C}$ deriva de uma linguagem de alto nível, o ALGOL 60 criada no ano de 1960. Justamente pelo fato da linguagem ser de alto nível foi que ela não obteve sucesso talvez porque os programadores da época, acostumados a programar muito "perto" do hardware, consideraram o ALGOL complicado para programar. A partir desta linguagem foram criadas outras, por exemplo, o CPL, criado em 1967 nas Universidades de Londres e Cambridge para trazer o ALGOL "mais próximo à realidade dos computadores" (PINHO, 1990). Da mesma forma que a linguagem ALGOL, não obteve sucesso, desta vez porque os projetistas de sistemas operacionais consideraram muito difícil de implementar. Com essa mesma origem, foram produzidas mais duas linguagens, a linguagem BCPL (Basic CPL), em Cambridge (1967) e a linguagem B (uma versão reduzida do CPL, em 1970), com compilador implementado por Ken Thompson, o chefe da equipe da Bell Labs (originalmente o braço de pesquisa e de desenvolvimento da AT\&T) que projetou o sistema operacional UNIX para os computadores DEC PDP11. Finalmente, a primeira versão de C foi criada por Dennis Ritchie em 1972 nos laboratórios Bell a partir da linguagem B, com modernizações que permitissem que fosse uma linguagem de execução rápida e portável, para que o UNIX fosse reescrito nessa linguagem e ganhasse a tão sonhada portabilidade - pudesse executar em vários hardwares de diferentes tipos.

\section{A.1 O programa principal do ODyn}

O programa ODyn é um programa procedural, isto é, orientado a procedimentos que dão modularidade e facilidade de manutenção ao código. Existem três formas de configurações iniciais para o programa: a primeira baseada no arquivo de parâmetros padrão o para1.in — o programa pode ser configurado para ler outro arquivo de parâmetros também em um arquivo batch — onde define-se que apenas serão preenchidas, no início, as bordas da grade com os tipos celulares especificados (condições de contorno); a segunda forma é baseada na leitura de uma matriz que também se encontra no arquivo de parâmetros; e, finalmente, a terceira forma é baseada na construção de uma matriz inicial baseada em parâmetros e ordem de preenchimento, utilizando-se das próprias regras de diâmetro de exclusão que basearão toda a disposição dos 
tipos celulares no decorrer do processamento das simulações. Vide as figuras 38 e 39 para entender o funcionamento do programa principal.

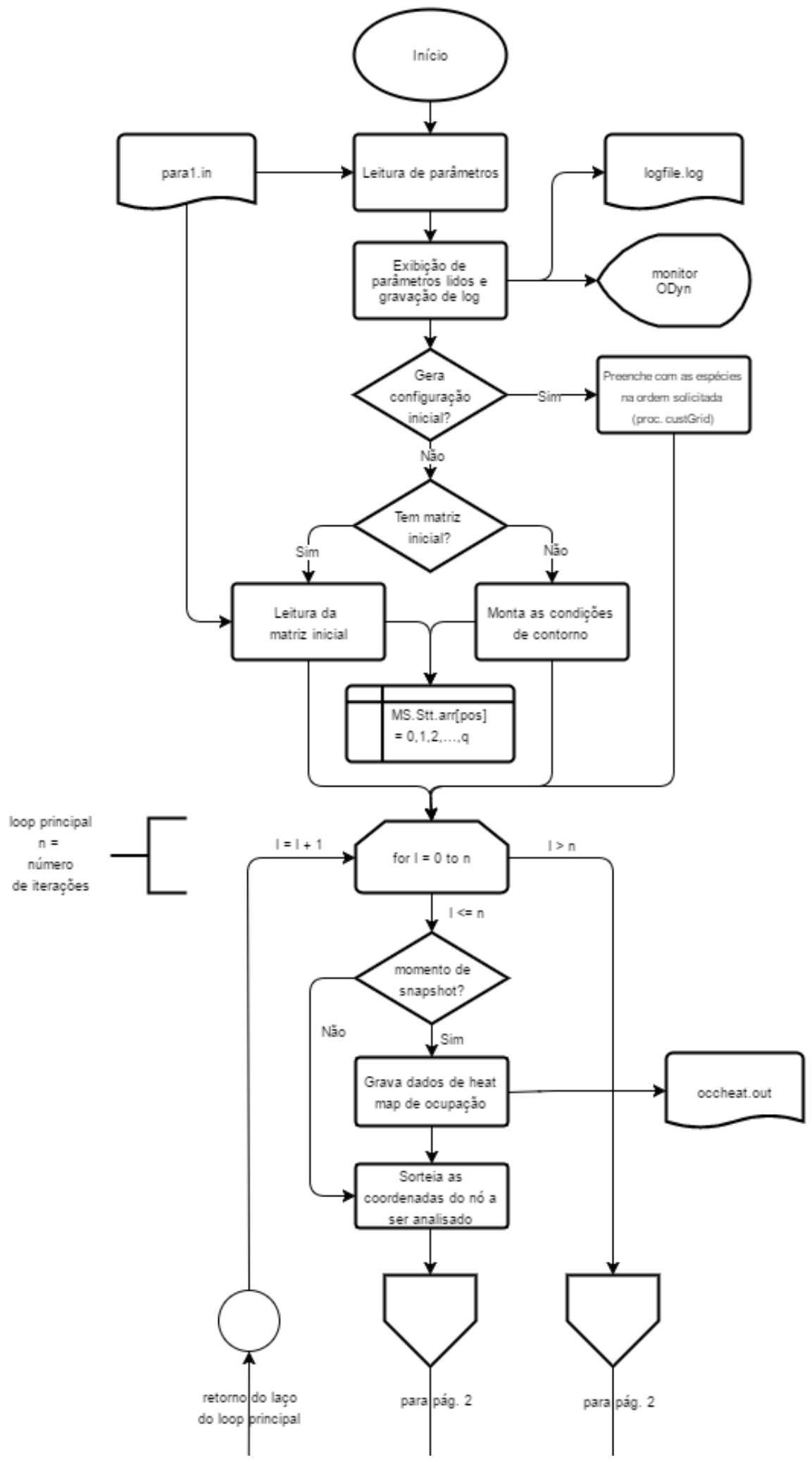

Figura 38 - Fluxograma do programa principal do ODyn - pág. 1 


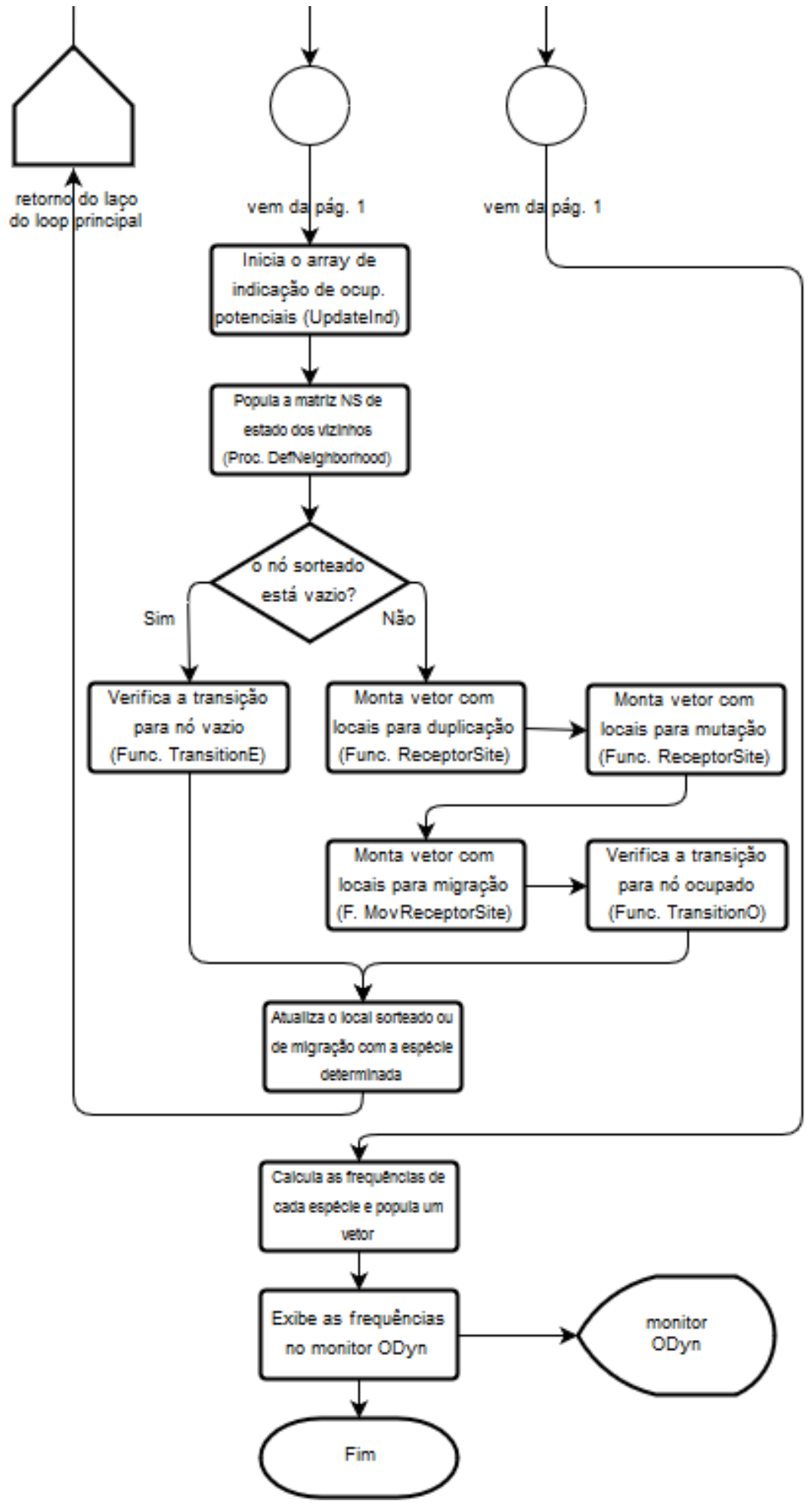

Figura 39 - Fluxograma do programa principal do ODyn - pág. 2 


\section{A.2 ODyn - procedimentos e funções}

A partir do corpo do programa principal, são chamados os procedimentos ou funções que vão desempenhando atividades para processar a simulação. Durante todo o programa são feitas gravações no arquivo de log e exibidas no monitor as informações pertinentes ao processamento.

O primeiro trecho de código é o de leitura dos parâmetros já descritos no apêndice ??, lá são definidas as configurações que nortearão a execução da simulação pretendida. A partir de definições lidas do arquivo de parâmetros, novos parâmetros devem ser lidos, por exemplo, se o parâmetro booleano - tipo de dado primitivo que só pode possuir dois valores, 0 ou 1 bOrderNumber Ini estiver com o valor 1, significará que deveremos ler para a matriz nodeInit pares de valores onde o primeiro indicará qual o tipo celular que deverá "povoar" a grade e qual o número de indivíduos serão criados daquele tipo, assim definimos uma hierarquia de "povoamento" a ser usada pelo procedimento CustGrid que fará então esse preenchimento da matriz MS .Stt. arr [i], onde i é o i-ésimo elemento da grade (vide a seção A.2.1).

No laço de repetição principal do ODyn, primeiro é analisado se já é um momento de gravação de informações da configuração da grade (um instantâneo ou snapshot) para posterior reprodução dos heat maps para análise dos resultados da simulação. Seguindo o algoritmo, temos o sorteio das coordenadas do próximo nó a ser analisado para a transição na dinâmica de ocupação da grade. Feito isso, é necessário que seja feita uma atualização para o estado inicial do vetor Ind que representa a função indicadora, para isto é chamada a função UpdateInd (A.2.2). Depois é necessário analisar a vizinhança do nó para poder decidir qual serão as possíveis transições naquele momento para aquele nó sorteado, quem tem essa função é o procedimento Def Neighborhood (A.2.3). Com essa análise e todas as informações armazenadas nas variáveis do programa, parte-se para decidir qual será a transição, se o nó sorteado estiver desocupado (vazio) chama-se a função TransitionE (A.2.4) para indicar qual será o tipo celular sorteado, caso contrário, deve-se chamar as funções ReceptorSite (A.2.5) e MovReceptorSite (A.2.6) para verificar as possibilidades de duplicação normal ou com mutação e de migração celular, antes de chamar a função Transition0 (A.2.7) para indicar qual será o tipo celular e evento sorteado. Finaliza-se o ciclo com a atribuição de um novo tipo celular para o nó sorteado. O programa termina após executar o número de iterações solicitados e depois de efetuar o cálculo das frequências de ocupação de cada tipo celular (procedimento $\mathrm{CalcOcc}$ ) que são gravadas em um arquivo e também exibidas no monitor ODyn.

\section{A.2.1 Procedimento CustGrid}

O procedimento CustGrid, para poder "popular" a grade com a quantidade estipulada na configuração de elementos de cada tipo celular, deve desempenhar quase as mesmas funções do simulador como um todo. Para tanto, o procedimento faz uso também da função UpdateInd (A.2.2) e do procedimento DefNeighborhood (A.2.3), a seguir uma breve descrição deles. Vide as figuras 40 e 41 para entender o algoritmo. 


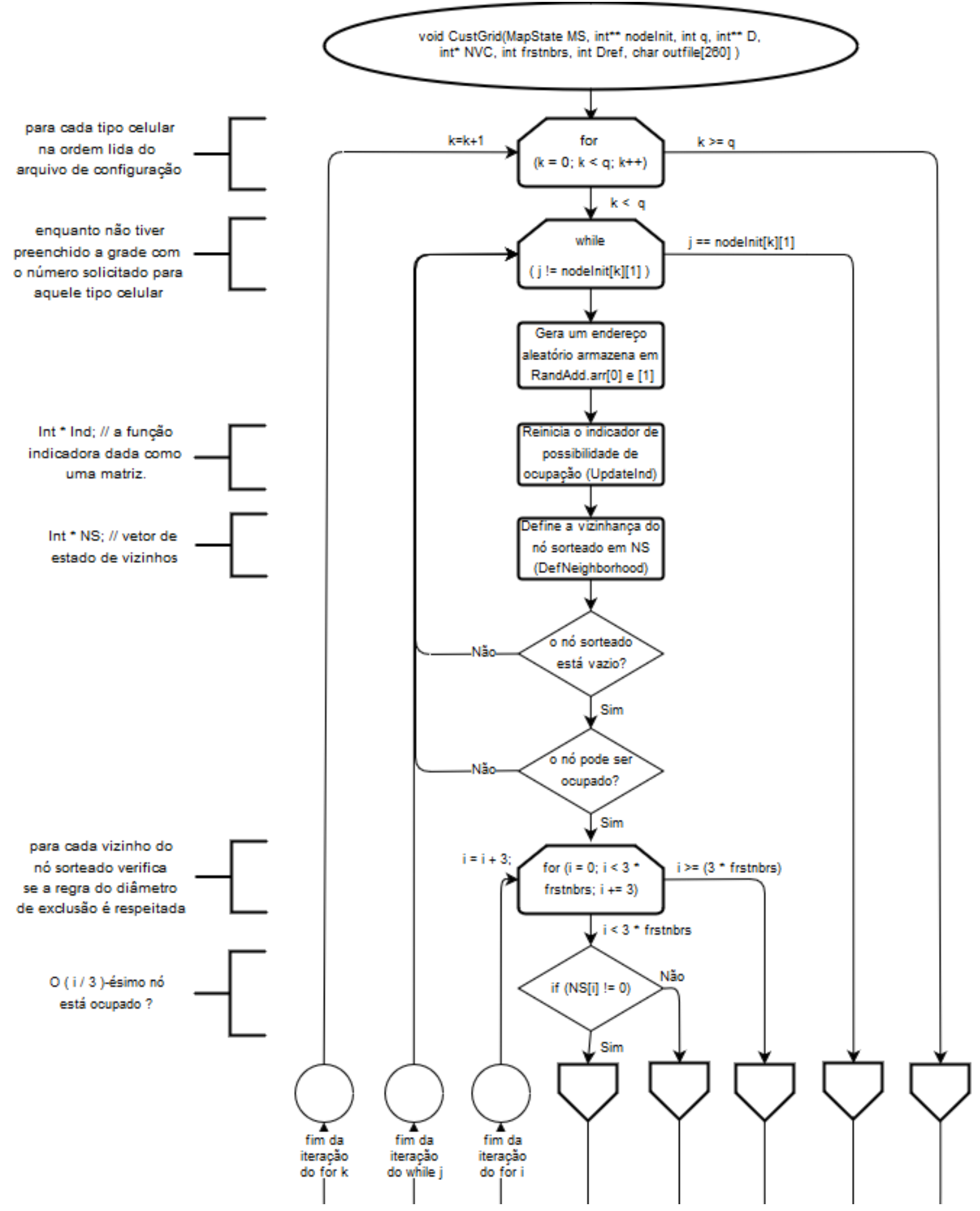

Figura 40 - Fluxograma do Procedimento CustGrid - pág. 1 


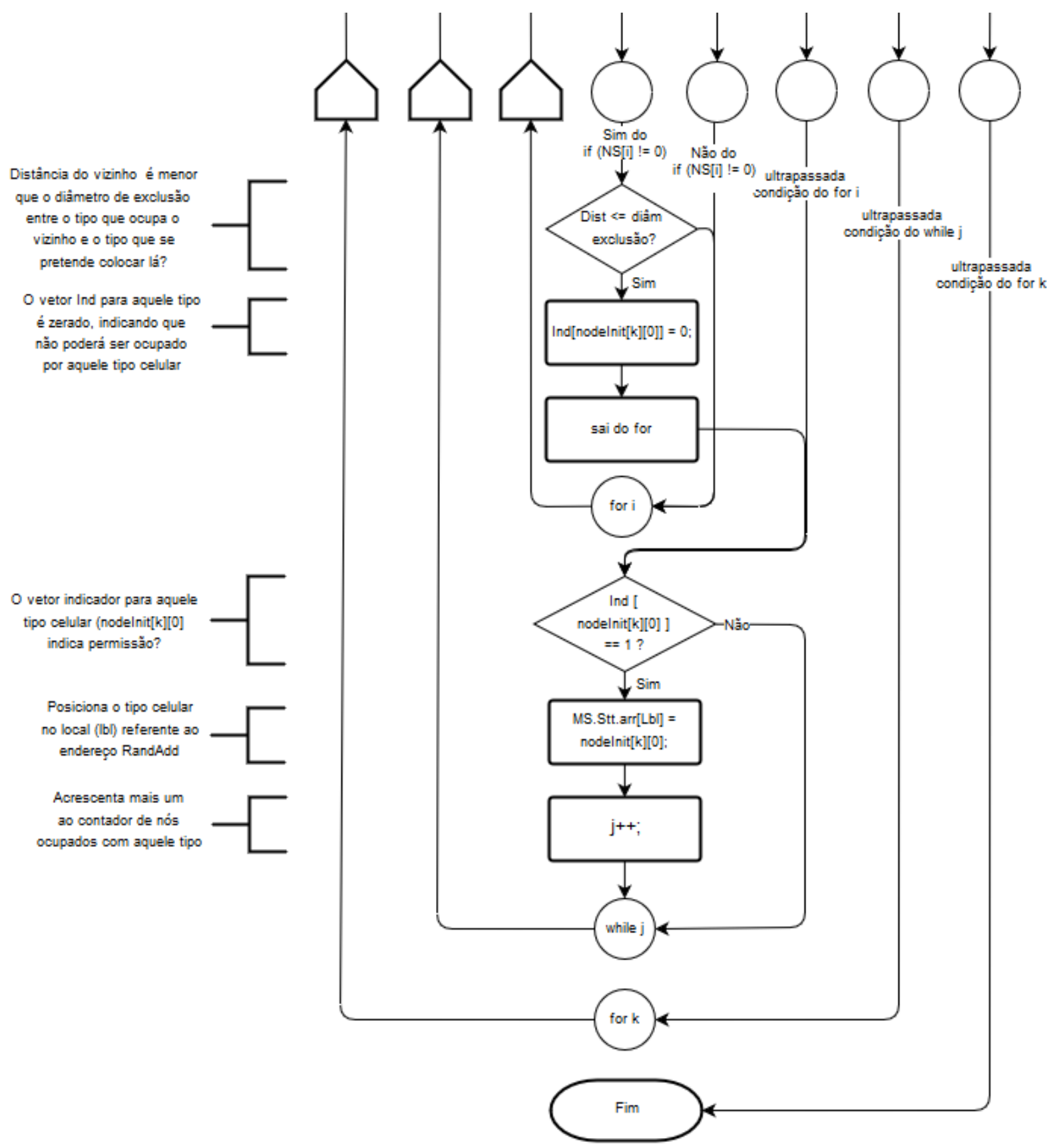

Figura 41 - Fluxograma do Procedimento CustGrid - pág. 2 


\section{A.2.2 Procedimento UpdateInd}

Este procedimento simplesmente reinicia o vetor Ind que representa a função indicadora $\mathbb{I}\left(\underline{x}^{v, y} \in A_{\Lambda}(\mu)\right)$, apresentada na equação ??, e deverá ter o valor 1 se um nó puder assumir o estado $i$ em razão do diâmetro de exclusão dos tipos celulares que ocupam os nós vizinhos, ou o valor 0 , caso contrário. As posições do vetor de zero a q (número de tipos celulares levados em conta na simulação) são referentes a ocupação do próprio nó, as outras serão disponibilizadas para os eventos de migração e mutação, que ocorrem nos vizinhos imediatos (ou first neighbors como no comentário do código apresentado na figura 42).

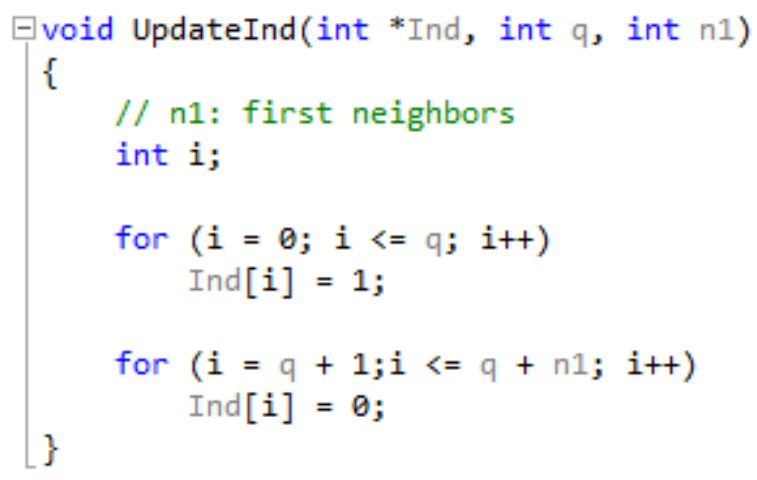

Figura 42 - Código do Procedimento UpdateInd

\section{A.2.3 Procedimento DefNeighborhood}

O procedimento DefNeighborhood, como o próprio nome em inglês - abreviado de define neighborhood - significa, tem a função de verificar e definir a vizinhança de um determinado nó, cujo endereço em forma de coordenadas é passado como parâmetro na matriz RandAdd (figura 43).

Para fazer a análise dos nós vizinhos é chamada a função AnNeighborhood (A.2.3.1), que vai montar um vetor chamado NS (de Neighbors States). Após a montagem desse vetor é chamada a função IndSite (A.2.3.2), que verifica a restrição do diâmetro de exclusão para atualizar o vetor Ind, indicador de possibilidade de ocupação.

Existem as versões dessas duas funções que são chamadas quando na parametrização é configurado o controle de transição. O controle de transição é usado quando se quer implementar a simulação de mutação, dessa forma, uma determinada espécie só pode "surgir" de uma outra especificada para isso. Com esse intuito, foram criadas as versões DefNeighborhoodTrCtrl e IndSiteTrCtrl. A única diferença desse procedimento e dessa função é que fazem uso de uma matriz chamada $\operatorname{TrCtrl}[i][j]$ que recebe o valor 1 quando pode ocorrer a transição da espécie i para a espécie j e 0 , caso contrário. 


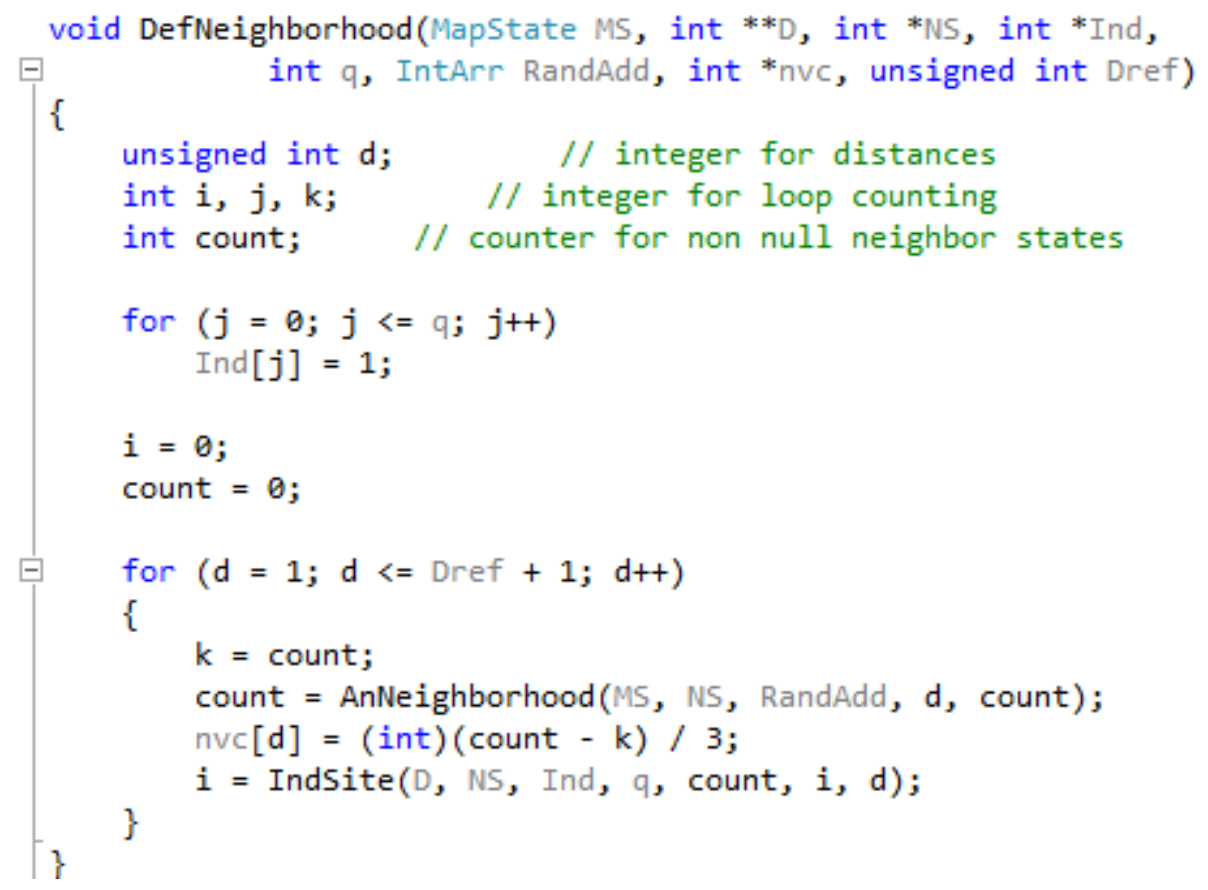

Figura 43 - Código do Procedimento DefNeighborhood

\section{A.2.3.1 Função AnNeighborhood}

A função AnNeighborhood (figuras 44 e 45) monta o vetor de estados dos vizinhos chamado NS, com três posições para cada nó, a primeira posição representando o estado atual do nó e, as outras duas, representando as coordenadas do nó. O parâmetro dist recebe a distância do nó no endereço RandAdd que é o limite dos vizinhos até onde deve ser montado o vetor.

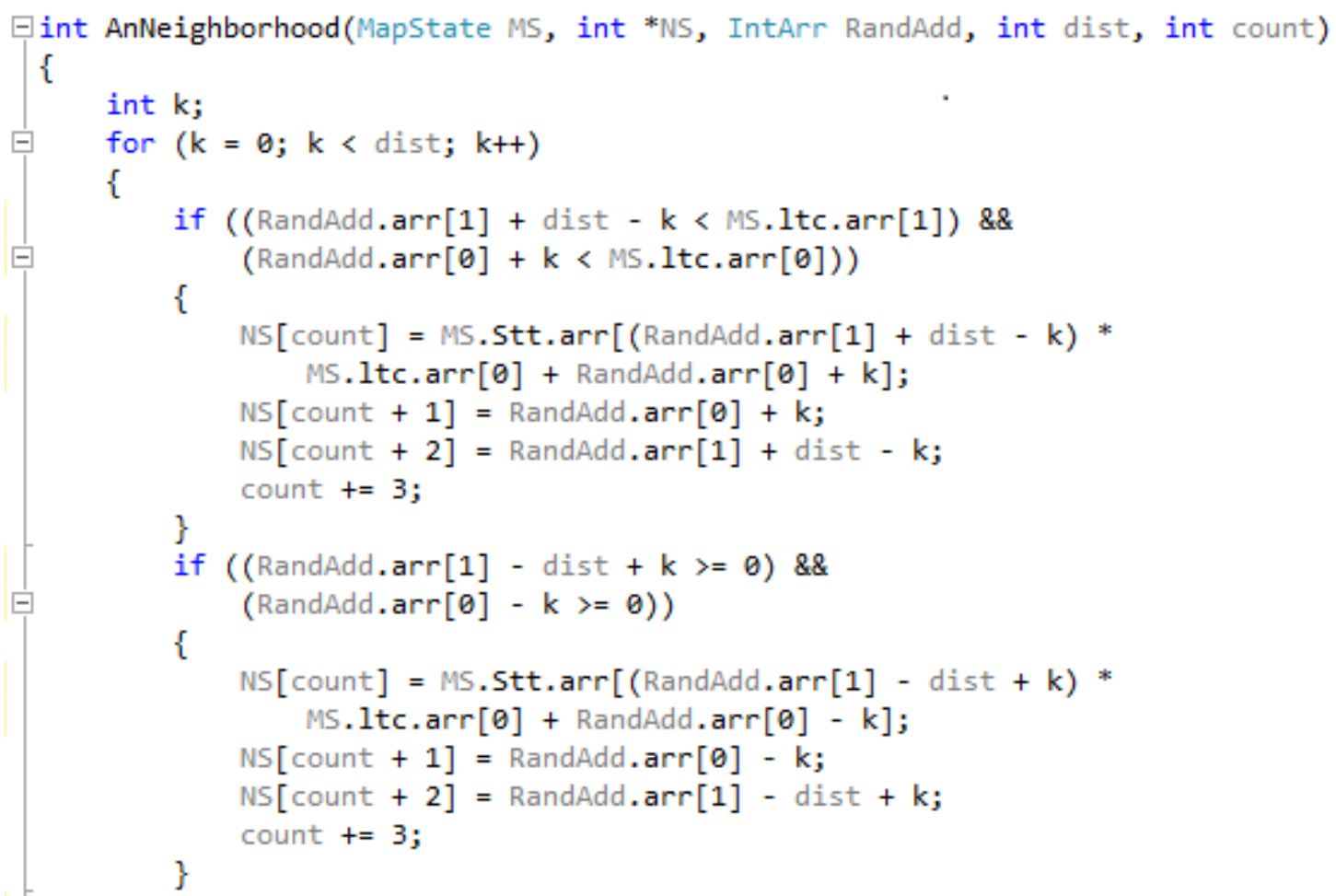

Figura 44 - Código da Função AnNeighborhood - pág. 1 


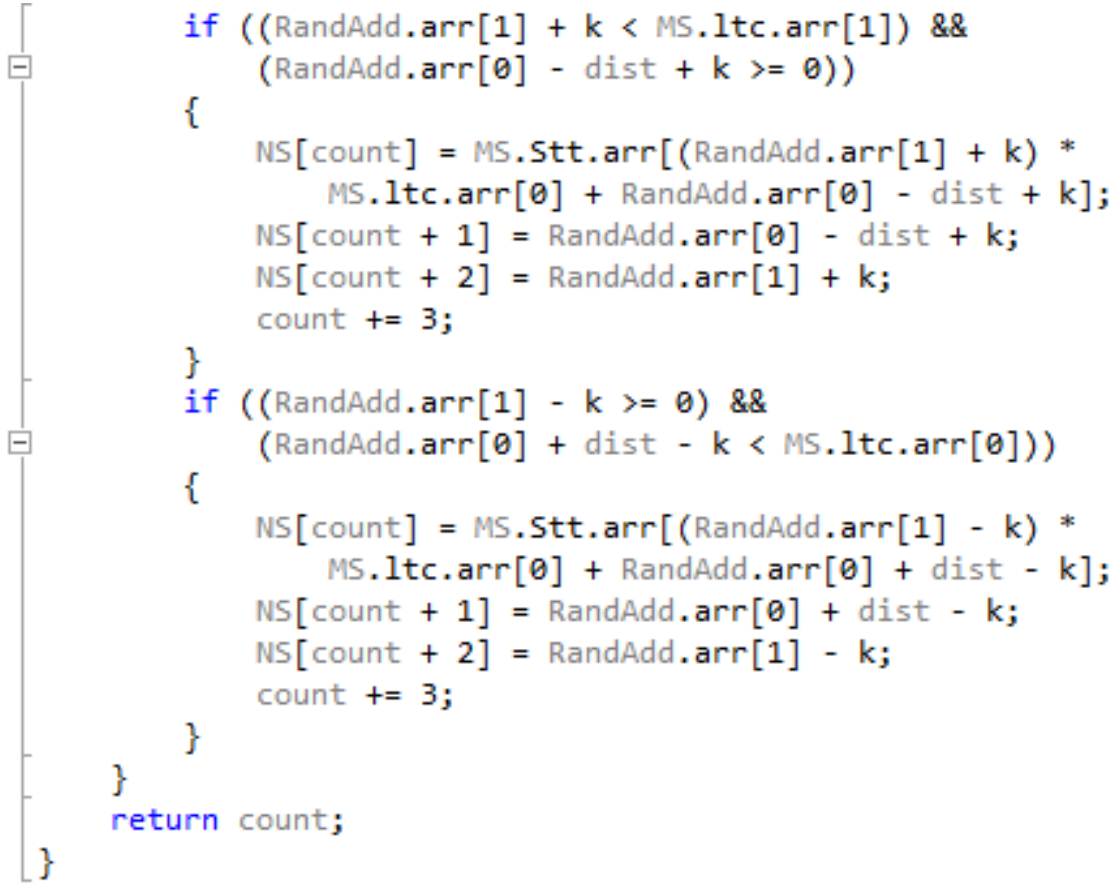

Figura 45 - Código da Função AnNeighborhood - pág. 2

\section{A.2.3.2 Função IndSite}

A função IndSite (figura 46) recebe como parâmetros a matriz D [i] [j] (diâmetro de exclusão entre os tipos celulares i e j, o vetor NS que contém os vizinhos significativos do nó do endereço RandAdd (outro parâmetro), além de dist que é a distância sendo analisada naquele momento e count que é o contador de elementos do vetor NS analisados e que será retornado para o chamador da função.

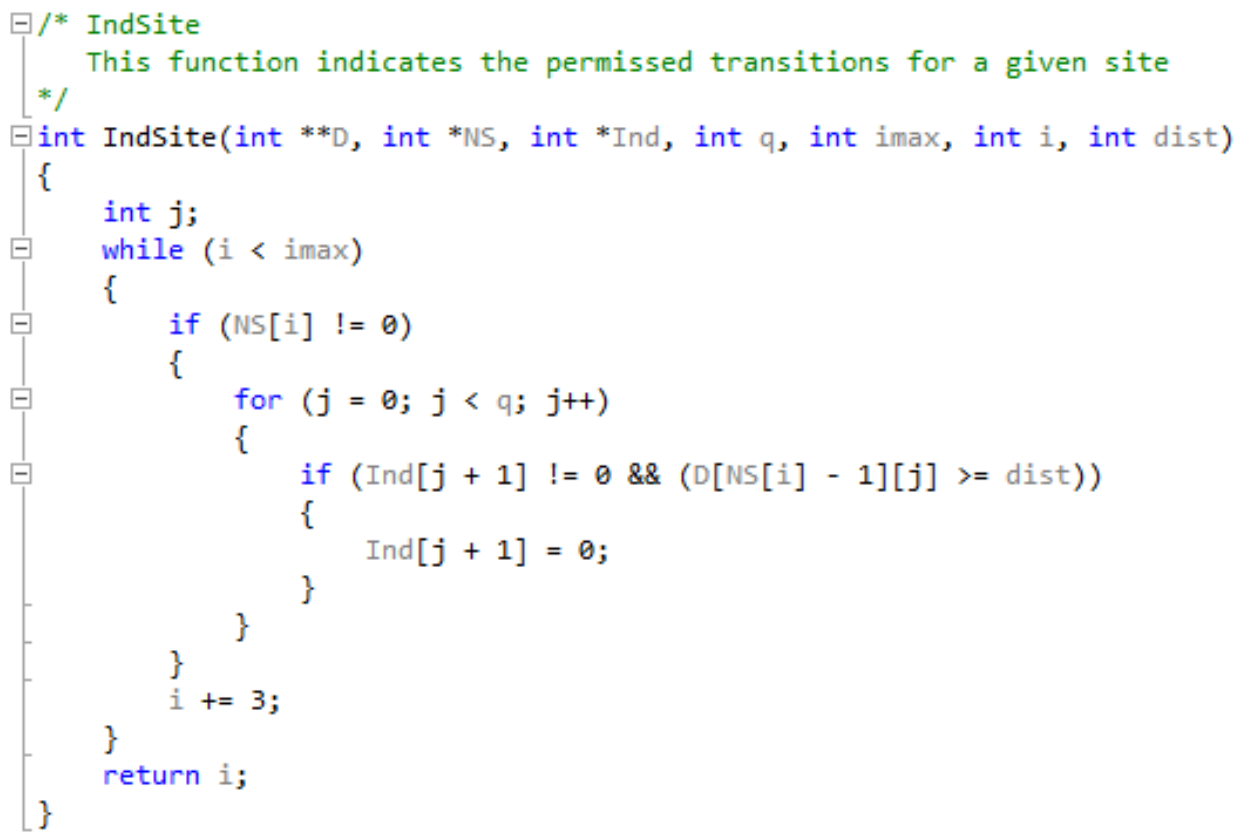

Figura 46 - Código da Função IndSite 
O objetivo da função IndSite é unicamente analisar a restrição do diâmetro de exclusão e atualizar o vetor de indicação Ind, no caso de IndSiteTrCtrl analisa também a matriz TrCtrl [i] [j]. Vide a figura 46.

\section{A.2.4 Função TransitionE}

A função TransitionE, com o código exibido nas figuras 47 e 48, tem como objetivo retornar o valor do tipo celular que ocupará o nó que se encontra vazio, ou qual vizinho imediato irá migrar para aquele nó. Para isso, é utilizado um vetor de probabilidades chamado Prob, nesse vetor, cada posição indicará a probabilidade de cada evento acontecer, sempre restrita à possibilidade de ocupação indicada pelo vetor Ind. No vetor Prob, as taxas de morte são acumuladas na posição Prob [0], indicando que a probabilidade do nó permanecer desocupado é a somatória dessas taxas, nas posições 1 até q são carregadas as taxas de duplicação de cada tipo celular e, finalmente, nas posições $q+1$ até $q+n 1, n 1$ é o número de vizinhos imediatos, temos as taxas de migração para cada tipo celular (por ora, o algoritmo está considerando estas taxas iguais para todos os tipos).

À medida que se vai carregando o vetor Prob as probabilidades armazenadas lá vão sendo acumuladas em uma variável que chamamos $Q$, este acumulador servirá para sortearmos o evento que ocorrerá da seguinte forma: primeiro geramos um número rrandômico e através de um cálculo que inclui a variável Q, geramos um número real entre 0 (inclusive) e 1 (exclusive) que é armazenado em uma varável chamada $r$, depois, em um laço de repetição, vamos percorrendo o vetor Prob a partir do índice do primeiro elemento que é o 0 , enquanto o valor de $r$ for maior que o de uma variável chamada AP que vai acumulando as probabilidades dos elementos de Prob já percorridos. No final desse processo, o índice do último elemento que foi analisado é retornado como o eleito para a próxima transição.

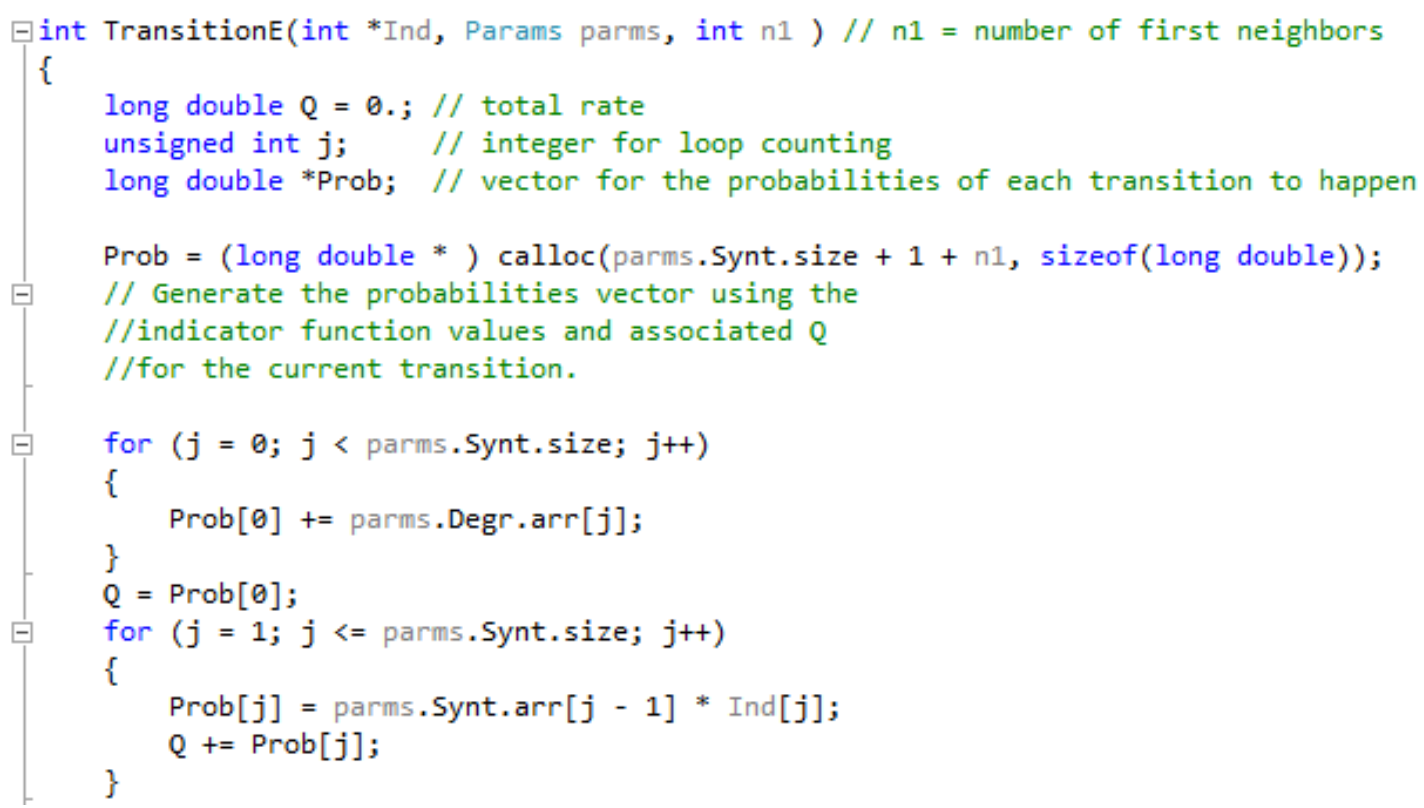

Figura 47 - Código da Função TransitionE - pág. 1 


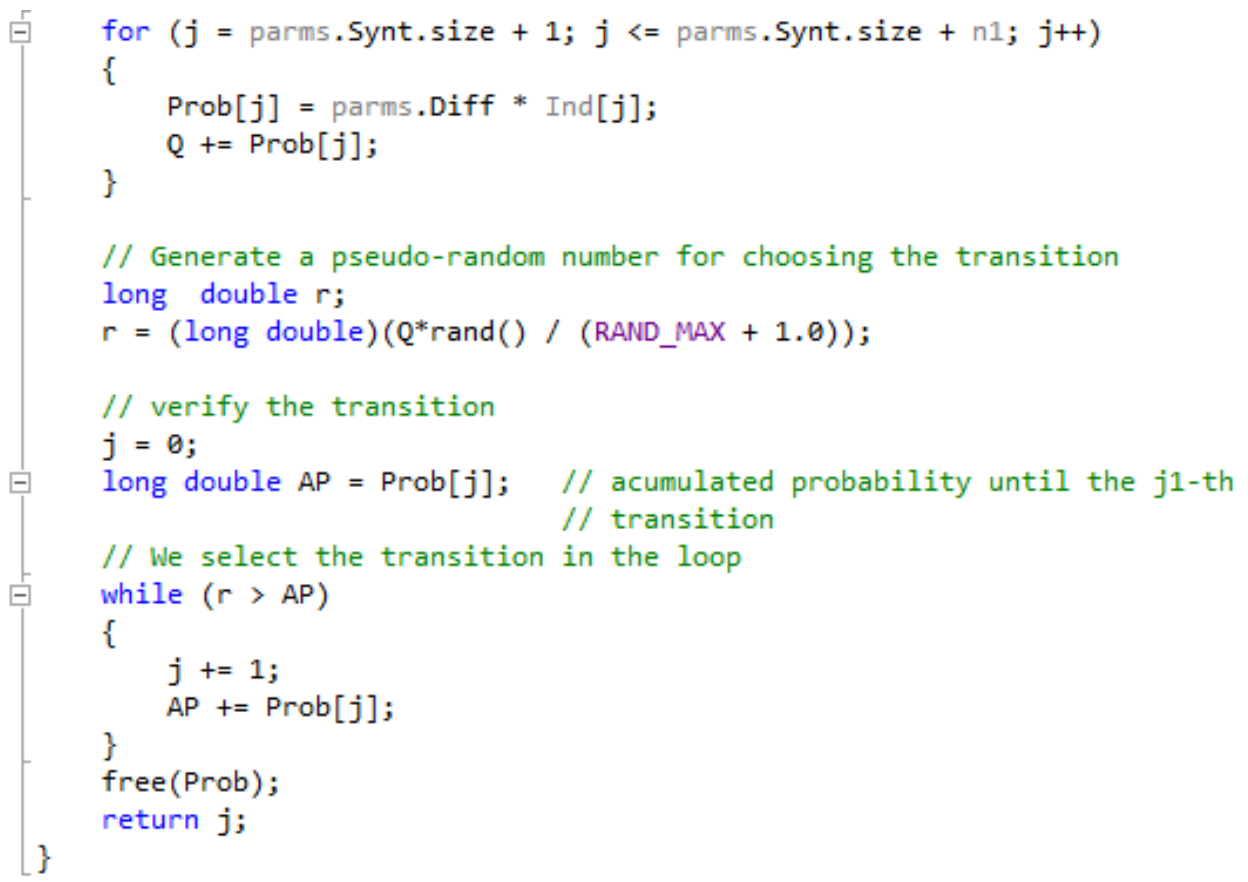

Figura 48 - Código da Função TransitionE - pág. 2

\section{A.2.5 Função ReceptorSite}

A função ReceptorSite, com o código exibido na figura 49, tem como objetivo preparar o vetor chamado NS (de Neighbors States) e o vetor indicador Ind. Para isso também faz uso da função AnNeighborhood (A.2.3.1) para montar o vetor de vizinhos. Após a montagem desse vetor é chamada a função IndReceptor (A.2.5.1), que verifica a restrição do diâmetro de exclusão para atualizar o vetor Ind, indicador de possibilidade de ocupação.

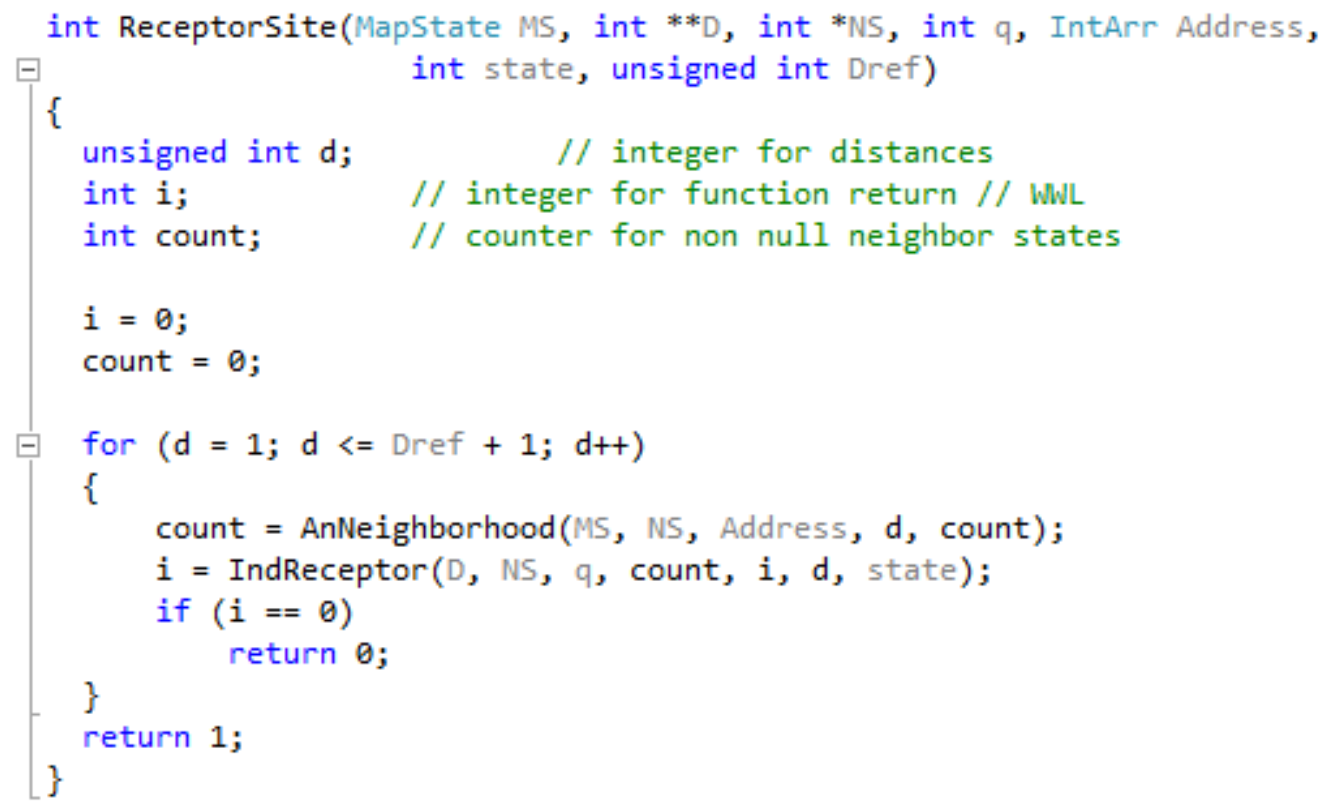

Figura 49 - Código da Função ReceptorSite

Essa função é chamada em duas ocasiões: a primeira para a construção do vetor de 
endereços advctr, que armazenará os locais possíveis de receber o mesmo tipo celular e a outra para o preenchimento de endereços de possíveis locais para receber o tipo celular mutante originado do tipo que ocupa o local sorteado, armazenado no vetor advmut. Se qualquer um dos nós não puder receber esses tipos celulares retornará 0 e para representar sucesso, a função terá o retorno de 1.

\section{A.2.5.1 Função IndReceptor}

Essa função, com o código representado abaixo (figura 50), retorna 0 se um dos vizinhos não respeitar a restrição do diâmetro de exclusão e imax, caso contrário.

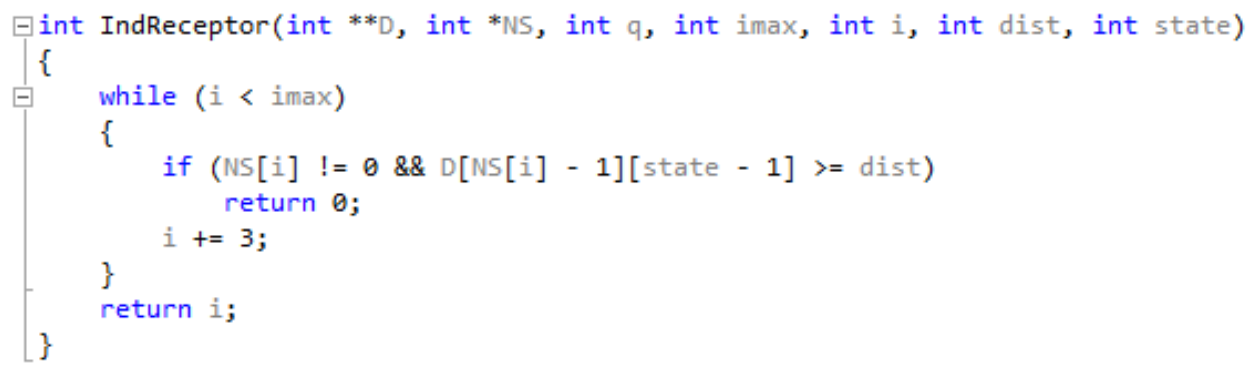

Figura 50 - Código da Função IndReceptor

\section{A.2.6 Função MovReceptorSite}

Essa função (figura 51) é chamada para a construção do vetor de endereços advmv, que armazenará os locais possíveis de receber o mesmo tipo celular, que, nesse caso, deixará o local anterior para o novo local. Esse novo local só pode estar no domínio dos vizinhos imediatos.

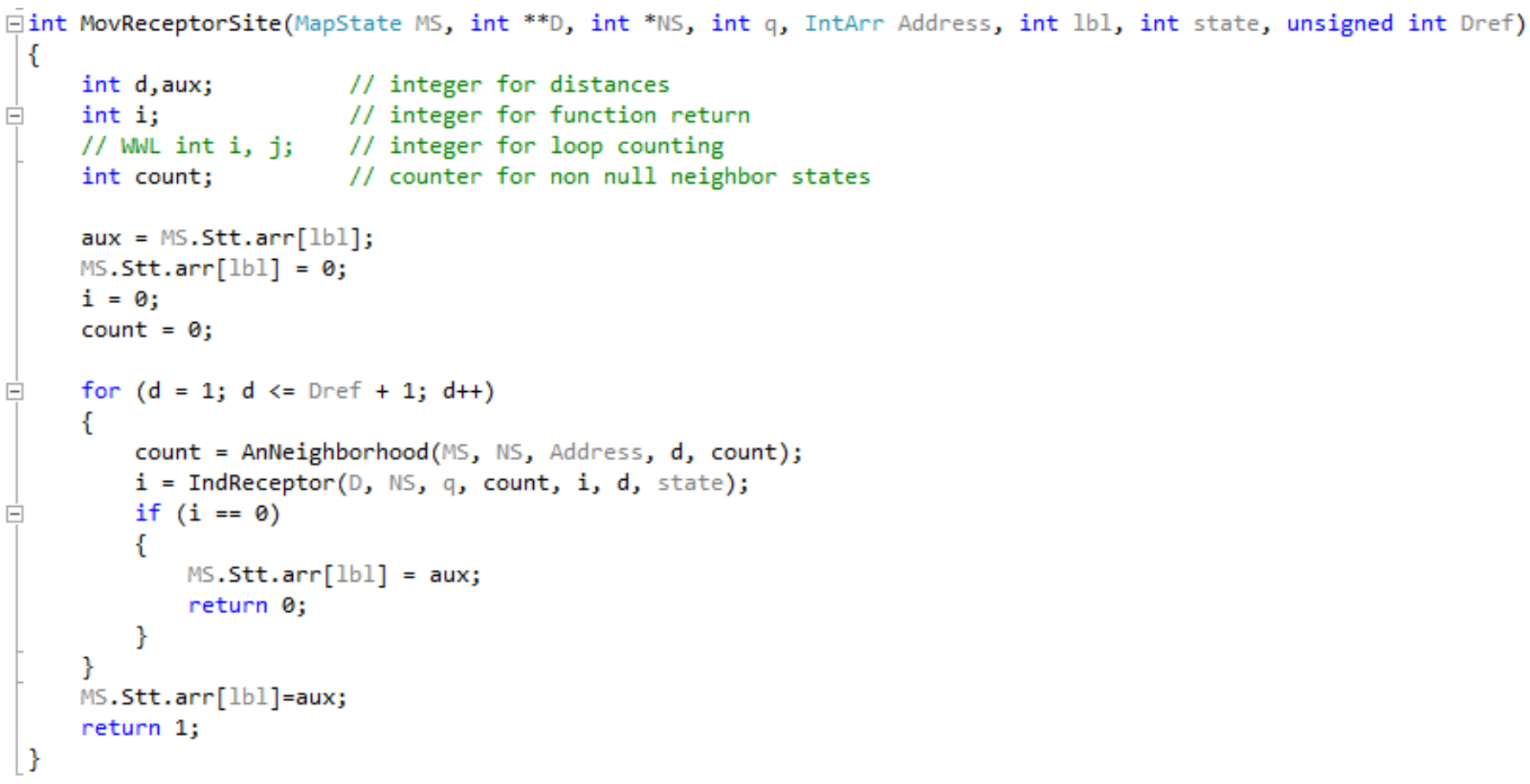

Figura 51 - Código da Função MovReceptorSite 
Faz uso, como a função ReceptorSite, das funções AnNeighborhood (A.2.3.1), para montar o vetor de vizinhos, e IndReceptor (A.2.5.1), para verificar a restrição do diâmetro de exclusão e atualizar o vetor Ind, indicador de possibilidade de ocupação. Também como a outra função, retornará 0 se qualquer um dos nós não puder receber o tipo celular da migração e 1 caso contrário.

\section{A.2.7 Função TransitionO}

A função Transitiono, com o código mostrado nas figuras 52 e 53, tem o mesmo objetivo da função TransitionE, porém, enquanto essa última é para o cálculo da transição para um nó desocupado (o "E"do seu nome vem do inglês Empty, ou vazio em português), a outra é para verificarmos qual será a transição de um nó que já está ocupado (o "O"do seu nome vem do inglês Occupied).

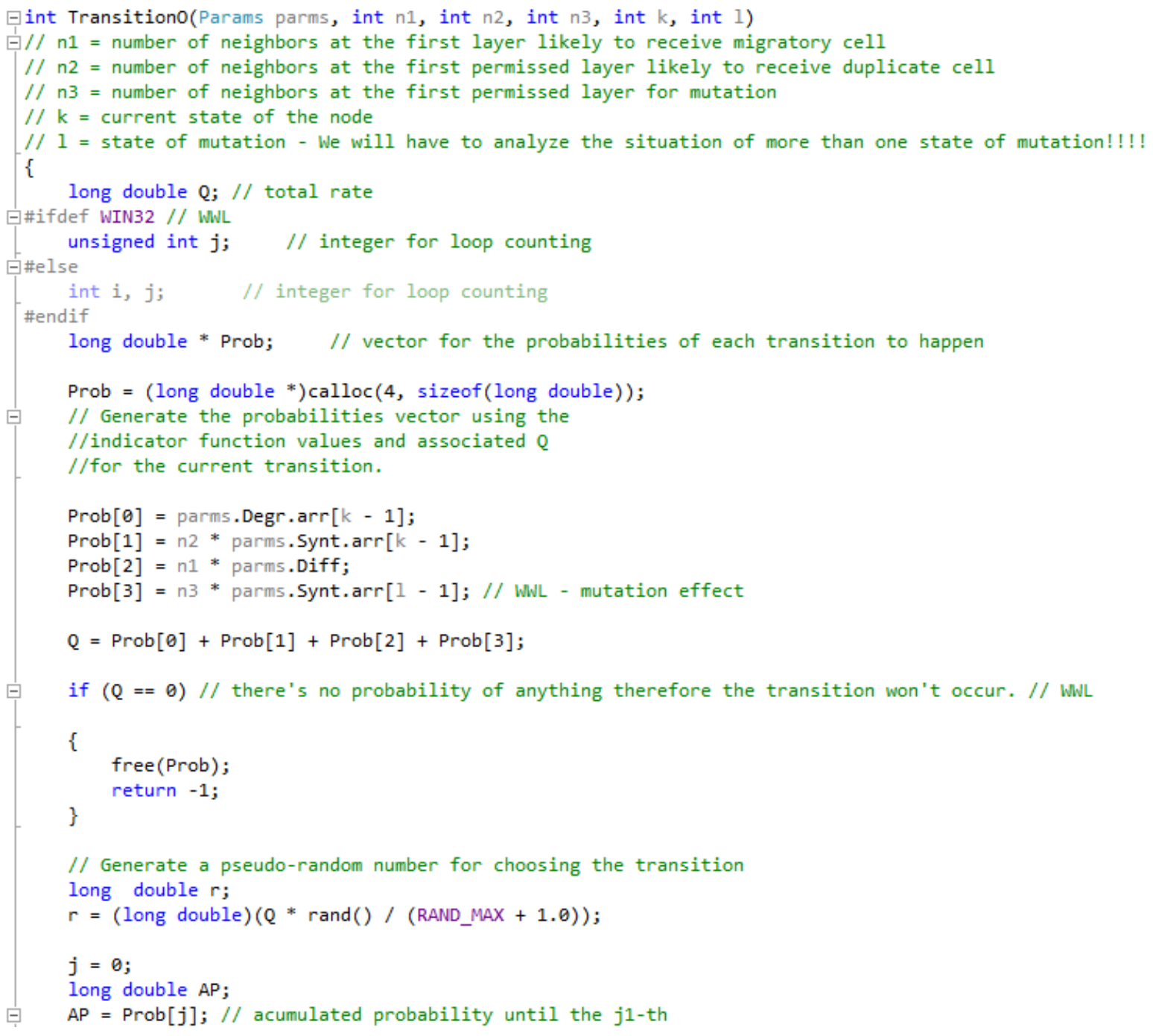

Figura 52 - Código da Função TransitionO - pág. 1 


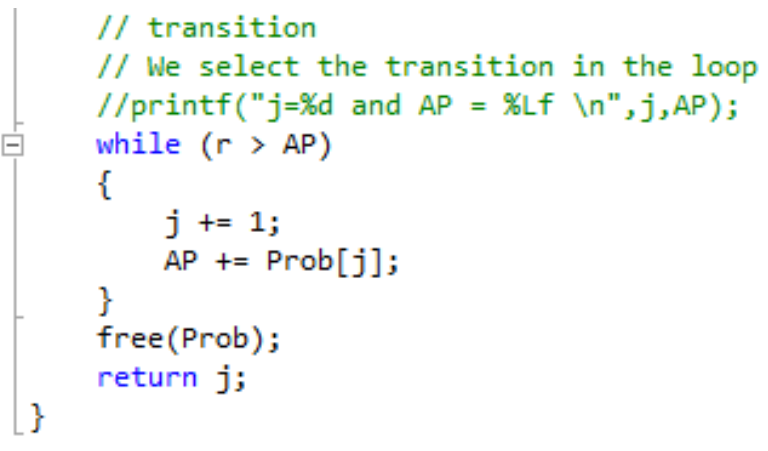

Figura 53 - Código da Função TransitionO - pág. 2

Tem objetivo de retornar os códigos que nortearão o simulador com o evento sorteado para acontecer naquela iteração. Assim, retornará, conforme vemos no trecho do código do programa principal representado abaixo na figura 54: o código 0 se o evento sorteado foi de morte do tipo celular que ocupava o nó, o código 1, se o evento escolhido for de duplicação, 2, se o evento for de migração e 3 se for escolhido o evento de mutação. Podemos notar que, no programa principal temos que lançar mão de outro número pseudorrandômico, agora armazenado em rnd para sortear entre os vários locais candidatos para cada tipo de evento, exceto o de morte celular.

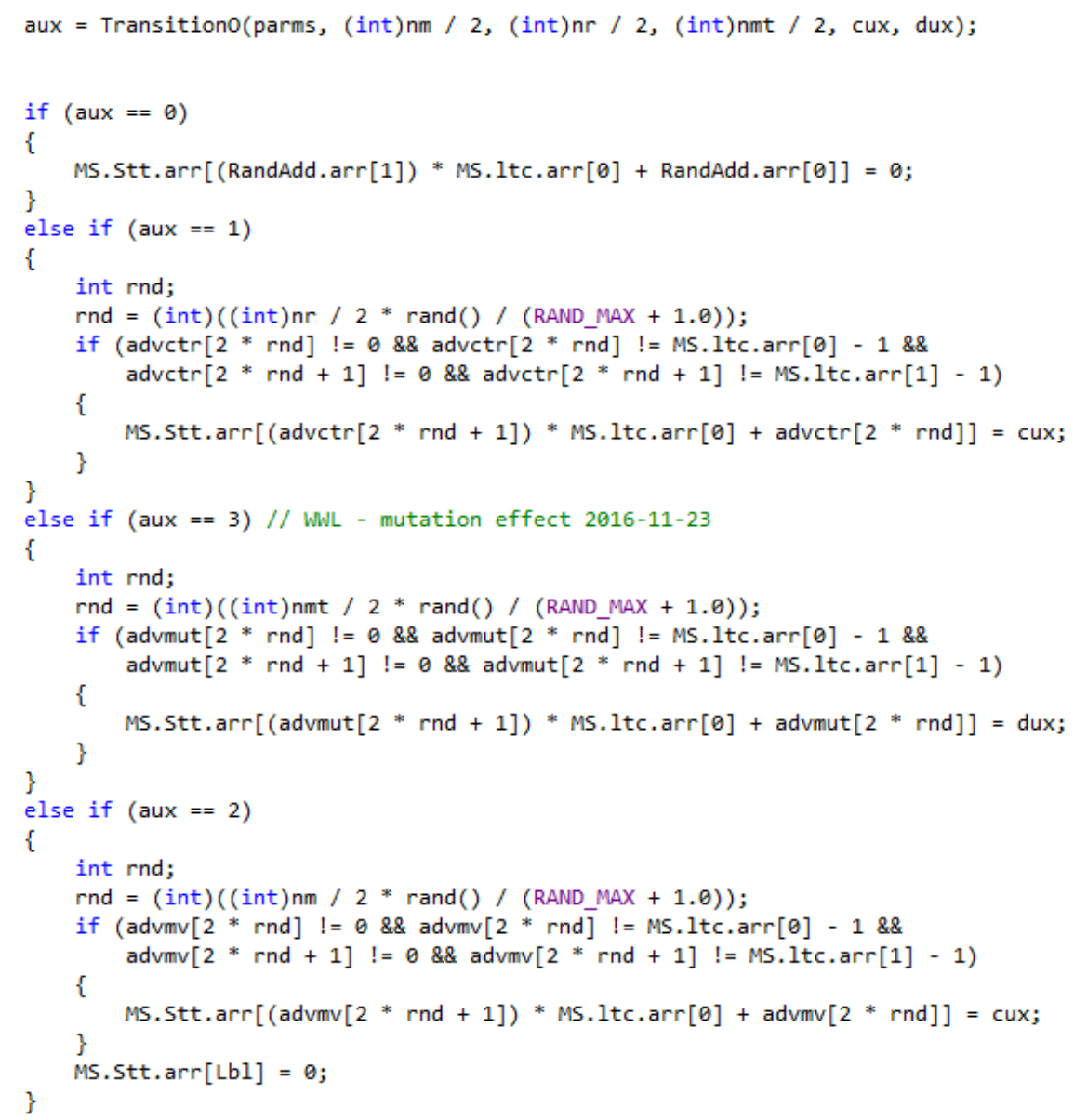

Figura 54 - Código do trecho do programa principal de decisão sobre o evento de transição 


\section{A.2.8 Procedimento CalcOcc}

O Procedimento CalcOcc tem como objetivo montar um vetor com as frequências de cada tipo celular. O código na linguagem $\mathrm{C}$ é apresentado na figura 55.

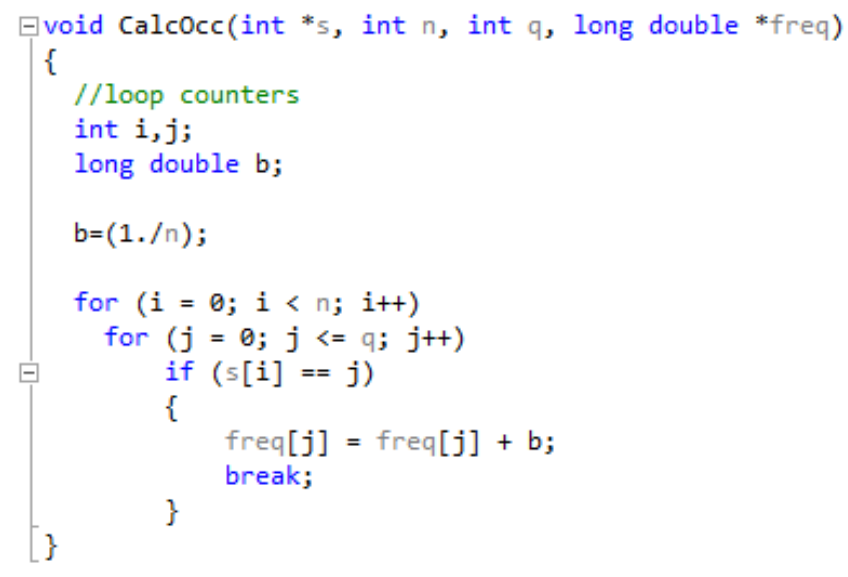

Figura 55 - Código do procedimento CalcOcc 